\title{
Now available online: Jan Verwey's unfinished manuscript on the breeding ecology of the Northern Lapwing Vanellus vanellus "Pair formation in the Lapwing, including its polygamy"
}

In this article, I introduce an unfinished manuscript on pair formation and polygamy in the Northern Lapwing Vanellus vanellus written by the late Jan Verwey based on studies he carried out in the Netherlands in the late 1920s and 1930s.

Gerhard C. Cadée

NIOZ Royal Netherlands Institute for Sea Research, PO Box 59, 1790AB Den Burg, Texel, Netherlands. gerhard.cadee@nioz.nl

A downloadable PDF of Jan Verwey's unfinished and unedited lapwing manuscript is now available as a supplement to the current issue of Wader Study at: http://www.waderstudygroup.org/publications/wader-study/waderstudy-volume124/waderstudy-volume-124-issue-1/

\section{INTRODUCTION}

Pairs of lapwings hanging against a blue sky above greening meadows form one of our finest symbols of spring.

These words, redolent of scientific writing in a bygone age, come from an unfinished manuscript on the breeding ecology of the Northern Lapwing Vanellus vanellus written by Jan Verwey in the 1930s and 1940s. Such colourful and expansive language is rarely seen in the terse texts of the 21st Century. It shows Verwey's enthusiasm for his subject, and this is probably the main reason for his study, which was accomplished mostly early in the morning before he went to work.

\section{JAN VERWEY}

From his early youth in Noordwijk, Jan Verwey (18991981) was interested in birds and their behaviour. $\mathrm{He}$ started publishing his bird observations in 1916 in the Dutch journal for field biology par excellence De Levende Natuur. In 1924, he studied the behaviour of the Grey Heron Ardea cinerea at a breeding colony, making observations from the attic window of his home in Middelharnis at Goeree-Overflakkee in the Province of Zeeland, resulting in an early and important publication on bird behaviour (Verwey 1930). During 1925-1927, he concentrated on lapwing behaviour in a polder near his birthplace at Noordwijk. He published on these observations in Verwey (1927).

Verwey went to work at the Laboratory for Sea Research in Djakarta, Indonesia, from 1927 to 1930, after which he became director of the Zoological Station in Den Helder,
Netherlands (which later became the NIOZ Royal Netherlands Institute for Sea Research). There he remained until his retirement in 1966. However, in the early years he again found time to study lapwings on the island of Texel near Den Helder and worked on a paper on all his lapwing data. Verwey was not a rapid writer; he wanted to read as much as possible on the subject and was not easily satisfied that he had done enough. Moreover, he had many other tasks as director of the Zoological Station.

After Verwey retired in 1966, the last years of his life were devoted mainly to another long manuscript on his coral work in Indonesia, which was also not finished when he died. This is now in the archives of the Naturalis Biodiversity Centre in Leiden and his data on the corals in Djakarta Bay have been used for tracking long-term changes since his time in Indonesia.

\section{VERWEY'S LAPWING MANUSCRIPT}

The existence of Verwey's lapwing manuscript was well known (see e.g. Baerends 1982, Postma 1982, and Röell 1996). After Verwey's death, his long-time friend, biologist W.H. van Dobben, saved the original manuscript from the disposal of Verwey's estate and carefully kept it, along with relevant letters from H.N. Kluyver, N. Tinbergen, and J.J.A. van Iersel. From these letters, it is clear that Verwey had started writing the manuscript as early as 1933. As it progressed, colleagues urged him to complete it and get it published (e.g. Kluyver in 1939 and 1941 as mentioned on the first page of the manuscript). By 1952, he had largely rewritten the manuscript and he expressed his sorrow that he had not published it earlier in a letter written that year to J.J.A. van Iersel. 
In 1941, the first part of the manuscript ("Account of the formation of couples, with a description of notes and movements") was sent to Ardea for publication (apparently it was not accepted). After the war, Verwey was urged to reconsider publication, as J.J.A. van Iersel wanted one of his students, P. Smit, to do some work on territory in lapwings on Texel. Verwey corresponded with N. Tinbergen on this matter, because he did not want unnecessary duplication of his work, but rather an addition to it. In a letter of 31 March 1950 to N. Tinbergen he says: "Nu ik langzamerhand tot uitwerken van allerlei kom zie ik ook de kievit kansen maken" [as I do get some time to work out miscellaneous papers, I may also finish the lapwing manuscript]. Verwey may have had in mind his paper on mussels and cockles in the Wadden Sea, which indeed appeared in 1952. Recently, we found another long, unfinished manuscript by Scheele \& Verwey on salinity variations in the Wadden Sea. This work was continued by $\mathrm{H}$. Postma who published together with Verwey on this work (Postma \& Verwey 1950) and continued hydrographic studies in the Wadden Sea for his thesis (Postma 1954).

Letters companying the manuscript indicate Verwey still planned to publish his paper on lapwing breeding behaviour in the 1950s, although he also expressed the opinion that ethology, as it had developed under the direction of Konrad Lorenz and Niko Tinbergen, both well known to Verwey (Fig. 1), had outdated his work (Postma 1982, p. 131).

\section{SUMMARY OF JAN VERWEY'S LAPWING MANUSCRIPT}

Verwey did not prepare an abstract or summary of his unfinished manuscript; I have therefore prepared the following summary in order to indicate its scope. Nevertheless, readers are advised to study the original document if they have more than a passing interest in its contents.

Verwey started his observations of Northern Lapwings in 1925, the year after his study of the breeding behaviour of the Grey Heron. For his lapwing observations no hide was needed. This enabled him to see clearly what was going on also above and behind his observation post.

Part I of the manuscript is entitled "Account of the formation of couples, with a description of notes and movements".

Pair formation starts with the male leaving the flock in which he spent the non-breeding season and selecting a territory. The borders of the territory are indicated by the song-flight, the form of which and song are described and compared with earlier descriptions. The song-flight also functions as display to attract a female. Aerial fighting for a territory occurs between males. Fights between females are rarer than between two males; a female only fights if there is another female in the neighbourhood of her male. On average the size of a territory is $c a .4,000$ $\mathrm{m}^{2}$.

The song-flight may be followed by a nesting-ceremony which can be divided into skipping, scraping and stick-

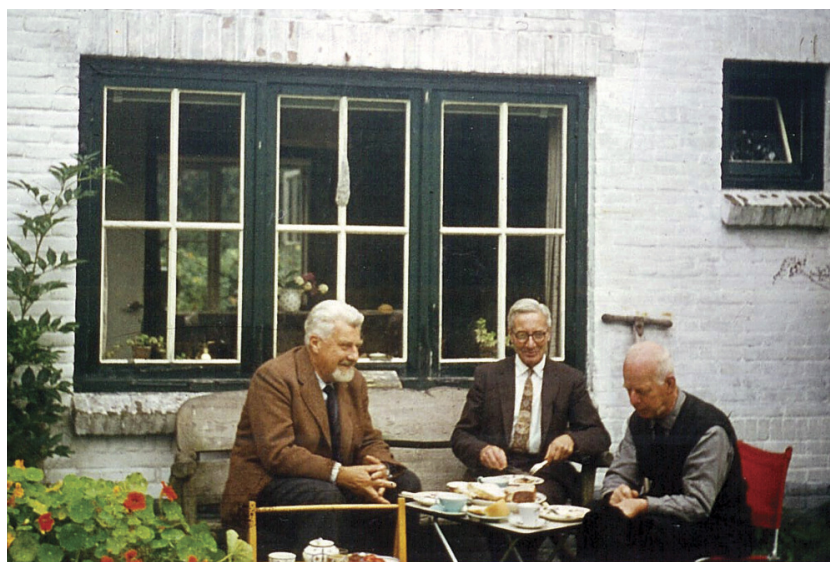

Fig. 1. Konrad Lorenz (left), Niko Tinbergen (centre) and Jan Verwey having tea outside Verwey's home in 1960.

throwing. During skipping, the male begins moving his body, wings and tail up and down followed by lowering his body with his breast on the ground. Scraping, a backward trampling (scraping) of the legs, follows. In most cases this causes the female to approach closely and she steps into the depression just made by the male and also starts scraping. The male now starts stick-throwing: taking roots, straw or grass from the ground and throwing this over his back. Copulation may occur directly after the song-flight, and the female and male may join each other in scraping. There are no pre- or post-copulation ceremonies. Copulation may take place 4-8 times during a morning observation period. Aerial fighting with other males entering the territory can be seen also as a courtship activity. The song-flight is only made by males; the different sounds during each part of it are described and compared with descriptions by earlier authors.

Part II is entitled "Polygamy in the Lapwing".

Lapwing pairs in isolated locations are certainly monogamous and the male may brood the eggs when the female leaves them and both protect their nest and the young against intruders. But polygamous inclinations are prevalent when more lapwings breed close together. Part II starts with those parts of the diary notes which deal with polygamy. These observations show that a male that 'marries' a second female in the presence of the first, does not tolerate it when either chases the other. However, he is a true 'husband' to both, who copulates now with the one, then with the other, and protects and defends both nests. Though he himself flirts with other females often enough, he does not tolerate that his wife flirts and may be angry with her as well as with his rival. Jealousy is the prime motive for all actions of the male's first wife, as soon as the male shows an interest in another second female. As a rule, the male can 'marry' (scrape with) a second female largely unhindered by his own wife. So dominance governs the behaviour of the male, submission that of the female. Verwey argues that lapwings should still be regarded as primarily monogamous. 
Forced copulation as observed commonly in the Grey Heron (Verwey 1930) does not occur in the Northern Lapwing. The size of the lapwing's territory combined with the fact that it is also used as its feeding area causes striking differences in behaviour between two monogamous species with polygamous inclinations.

Part II concludes with a list of published data on bigamy in birds mainly based on clutch sizes being greater than normal. By far the majority represent cases of true polygyny; very few cases of polyandry are reported. In some species the two females lay their eggs in the same nest. Bigamy is sometimes favoured by the passing of the first female into the non-copulatory stage, but arises without this favour in many cases. Bigamy appears more common in some birds than others. It is much more common in the Northern Lapwing than in the Grey Heron, which may be due to the size differences in territory and the fact that in the lapwing the territory also provides the birds' feeding area.

\section{THE ONLINE VERSION OF VERWEY'S LAPWING MANUSCRIPT}

In 1966, Theunis Piersma (now University of Groningen and Senior Research Scientist at NIOZ) suggested to me that I might try to have Jan Verwey's unfinished lapwing manuscript published in time for what would have been the commemoration of his 100th birthday in 1999. I therefore visited W.H. van Dobben in Wageningen and found there the manuscript that he had saved and carefully kept. Van Dobben and his wife received me very warmly and told me where to look for the manuscript upstairs, as van Dobben himself was unable to scale the stairs (in fact he died three years later; Kuipers 2001).

Joke Hart, the then director's secretary at NIOZ, very kindly retyped the manuscript to have it available in electronic form. Unfortunately, after she left, only a hard copy remained of her work. However, with the help of Bert Aggenbach and Nelleke Krijgsman (NIOZ) we were able to scan the hard copy and make a new PDF version of it, but by then Verwey's 100th birthday was long past. However, in 2016 'The Year of the Lapwing' in the Netherlands, I again took up the project. The manuscript is now made available online, thanks to the International Wader Study Group and the editors of this journal. The original manuscript is now stored in the Archives Heimans \& Thijsse Stichting (Amsterdam), which are saved in the University Library Amsterdam, Special Collections.

Verwey never completed the list of references for his manuscript. Therefore I have tried to make it as complete as possible, partly by using reprints from his reprint collection which was deposited at NIOZ. Two maps and some figures drawn by Luuk Tinbergen were missing from the manuscript. Van Dobben was very helpful in trying to locate the figures, but all searches were in vain. It is a pity we cannot produce the drawings made by Luuk Tinbergen, brother of Niko Tinbergen, as he was not only a famous biologist, but also a very skilful draftsman as we know from the various books he illustrated. (a)

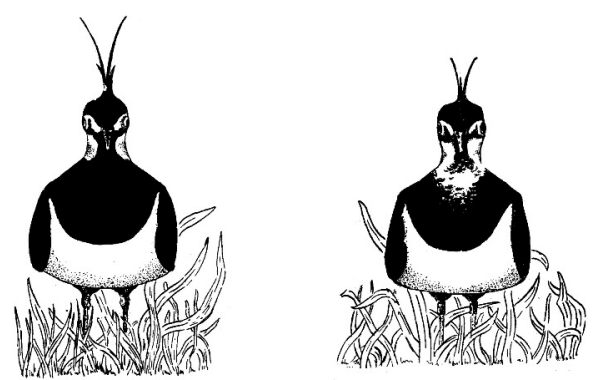

(b)

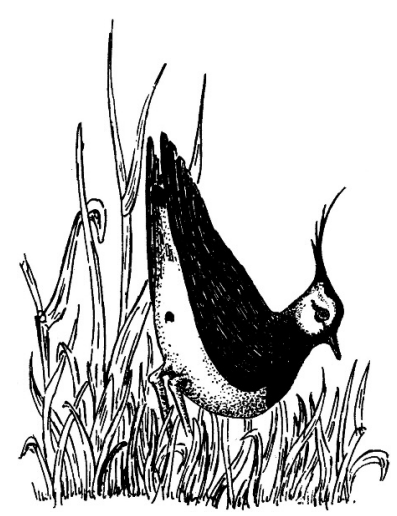

(c)

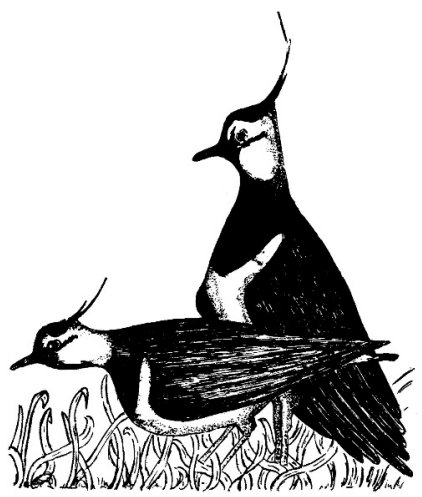

(d)

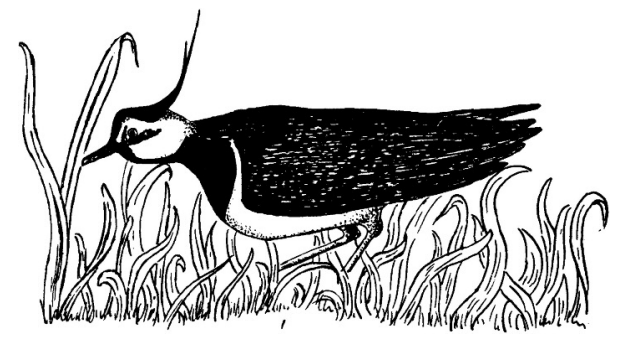

(e)

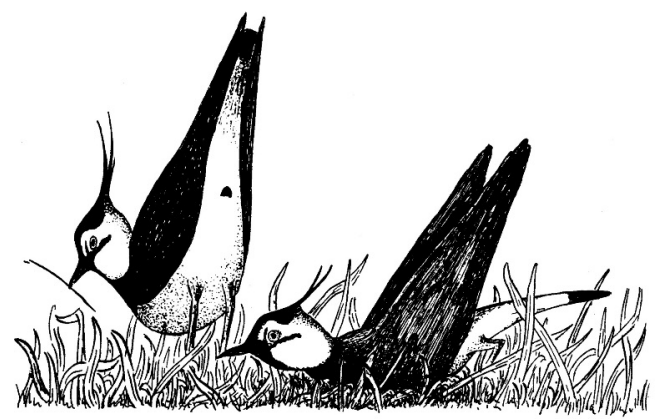

Fig. 2. Drawings showing pair-formation behavior in the Northern Lapwing from Rinkel (1940): (a) Lapwing male left and female right showing differences in plumage, (b) Male Lapwing trying to impress, (c) Coition refused, (d) Stiff attitude, (e) Mutual scraping ceremony. 
As it is likely that the missing drawings were similar to those demonstrating pair-formation behaviour in lapwings published by Rinkel (1940), Rinkel's drawings are reproduced here to help the reader understand Verwey's text (Fig. 2).

It should be noted that, apart from correction of a few obvious errors and deletion of references to the missing drawings, the online version has not been edited. Therefore the text retains the authenticity of Jan Verwey's language which is so characteristic of scientific writing in the first half of the 20th Century.

\section{APPRAISAL OF JAN VERWEY'S LAPWING MANUSCRIPT IN THE LIGHT OF CURRENT KNOWLEDGE}

Clearly Jan Verwey's lapwing manuscript is of considerable historic interest, but what is its value to modern science? Assessing that is outside my area of expertise. Therefore Ingvar Byrkjedal and Terje Lislevand (University Museum of Bergen, Norway) have kindly studied the manuscript and provided the following appraisal.

$$
\text { 水水水 }
$$

Jan Verwey's study contains a lot of detailed descriptions of postures and movements made by lapwings during pair formation. Much of this is basically a review of what other researchers had found, combined with Verwey's own observations. These descriptions are accurate and based on keen observation, a remarkable feat considering the optical tools of the time.

The main findings reported in the paper can be summarized as follows:

The author reports several cases of polygyny in lapwings, although from his point of view the species should still be regarded as primarily monogamous. Polygyny in lapwings had already been described by others when Verwey wrote about it and this is referred to and discussed by the author. More recent studies in several European countries have demonstrated that polygyny is in fact a rule in the species (e.g. Berg 1993, Byrkjedal et al. 1997, Parish et al. 1997, Grønstøl et al. 2003). For instance, our own studies in Norway showed that about $40 \%$ of males typically had $>1$ mate simultaneously breeding on the territory. Verwey also reports a few cases of 'bachelor' males, and this is known from modern lapwing studies as well. This finding is important for the discussion of why lapwings are polygynous, since it suggests that polygyny could not be caused by a surplus of females in the study populations. Verwey might in fact have been the first to realize this point in lapwings.

Verwey used individual details in plumage marks to identify female lapwings. This method has been used also in modern studies, although in a more methodic way. Verwey might have been the first researcher to realize this individual variation in the appearance of lapwings, and used it in his behavioural studies, although he put less weight on the fact that also males show such individually variable plumage characters.
In his description of polygynous matings, Verwey reports several cases of female-female aggression as well as male interventions to part aggressive females (mate and prospective extra mate). This in itself would have been worth reporting when Verwey first tried to publish his study but is also now well described from more recent work (Liker \& Székely 1997, Byrkjedal et al. 2013, Grønstøl et al. 2014).

The part about polygamy largely consists of direct extracts from Verwey's own field notes, with a lengthy discussion and a review of polygamy in birds as it was known at the time of writing. This review is of course now outdated, since avian breeding systems have received a lot of attention from ornithologists during recent decades.

A more condensed ('digested') version of the described behaviour and postures would have been highly preferable, although writing this would admittedly be a demanding job. One can only regret that the manuscript does not contain illustrations of postures and movements; even simple sketches would have been of great help.

In general, Verwey discussed his observations in relation to classical ethological drive concepts, the usual framework of behavioural studies of the time. Observations of behaviour are not related in any quantitative way to specific contexts or situations, and samples are generally small. In addition, the author makes his conclusions from an anecdotal treatment of his observations - also a common practice of the time. If published in the 1930s, the paper would certainly have been a classic that undoubtedly would have influenced the major treatments by e.g. Laven (1941) and Rinkel (1940). Now, however, we cannot see that the manuscript provides any new information about lapwing breeding behaviour/biology.

As an overall evaluation of this manuscript and its significance we would therefore say that the reported details about behaviour can nowadays be readily found in handbooks and a number of research papers. The present value of the manuscript is in our view twofold:

Historical, not least regarding scientific methodology (anecdotal vs. modern quantitative analyses), although there are of course many other examples of this which were actually published. For students of lapwing biology the manuscript might also have a historic value.

Ideas for proximate (drive-related) behavioural hypotheses that could be studied (and tested by modern experimental or observational design), should such again come into focus in behavioural studies.

\section{ACKNOWLEDGEMENTS}

Many thanks are due to Theunis Piersma, who in 1996 suggested making this manuscript available on line, to the late W.H. van Dobben who carefully saved Verwey's lapwing manuscript, to Joke Hart for typing the partly handwritten manuscript, to Edward Bonne (NIOZ) for encouraging me to continue, to Bert Aggenbach and Nelleke Krijgsman (NIOZ) who made the PDF, and the Royal Netherlands 
Institute for Sea Research for offering facilities to do this work. I am also very grateful to the editors of Wader Study, Yvonne Verkuil and Humphrey Sitters, for making Verwey's manuscript available, the latter in particular for his great help with the text, and finally lapwing researchers Ingvar Byrkjedal and Terje Lislevand (Bergen) whom Humphrey Sitters asked to appraise Verwey's manuscript in relation to current knowledge.

\section{REFERENCES}

Baerends, G. 1982. Jan Verwey (12 mei 1899-24 september 1981). Jaarboek 1981 KNAW: 179-186. [In Dutch]

Berg, Å. 1993. Habitat selection by monogamous and polygamous Lapwings on farmland - the importance of foraging habitats and suitable nest sites. Ardea 81: 99-105.

Byrkjedal, I., G. Grønstøl, T. Lislevand, K.M. Pedersen, H. Sandvik \& S. Stalheim. 1997. Mating systems and territory in Lapwings Vanellus vanellus. Ibis 139: 129-137.

Byrkjedal, I., T. Lislevand \& G. Grønstøl. 2013. Rapid sampling of males and territories by female northern lapwing, Vanellus vanellus. Wilson Journal of Ornithology 125: 809-811.

Grønstøl, G.B., I. Byrkjedal \& Ø. Fiksen. 2003. Predicting polygynous settlement while incorporating varying female competitive strength. Behavioral Ecology 14: 257-267.

GrØnstØl, G., T. Lislevand \& I. Byrkjedal. 2014. Resident female Northern Lapwings Vanellus vanellus fight to exclude settlement of secondary females. Ibis 156: 461-465.

Kuipers, P.J.C. 2001. Willem Hilbrand van Dobben, 19071999. Levensberichten KNAW 2001: 23-28. [In Dutch]
Laven, B. 1941. Beobachtungen über Balz und Brut beim Kiebitz (Vanellus vanellus L.). Journal für Ornithologie Ergänzungsband 3: 1-64. [In German]

Liker, A. \& T. Székely. 1997. Aggression among female Lapwings, Vanellus vanellus. Animal Behaviour 54: 797-802.

Parish, D.M.B., P.S. Thompson \& J.C. Coulson. 1997. Mating system in the Lapwing Vanellus vanellus. Ibis 139: 138-143.

Postma, H. 1954. Hydrography of the Dutch Wadden Sea. Archives Néerlandaises de Zoologie 10: 405-511.

Postma, H. 1982. Jan Verwey, 1899-1981. Netherlands Journal of Sea Research 15: 131-140. [Includes a bibliography]

Postma, H. \& J. Verwey. 1950. Resultaten van hydrografisch onderzoek in de Waddenzee. Waddensymposium, Tijdschrift van het Koninklijk Nederlands Aardrijkskundig Genootschap 67: 3-33. [In Dutch]

Rinkel, G.L. 1940. Waarnemingen over het gedrag van de Kievit (Vanellus vanellus (L.) gedurende de broedtijd. Ardea 29: 108-147. [In Dutch]

Röell, D.R. 1996. De wereld van instinct. Niko Tinbergen en het ontstaan van de ethologie in Nederland (1920-1950). Erasmus Publishing, Rotterdam. [In Dutch]

Verwey J. 1927. Waarnemingen bij Noordwijk. De Levende Natuur 32: 199-212, 236-242. [In Dutch]

Verwey, J. 1930. Die Paarungsbiologie des Fischreihers. Zoologische Jahrbücher 48: 1-120. [In German]

Verwey, J. 1952. On the ecology and distribution of cockle and mussel in the Dutch Waddensea, their role in sedimentation and the source of their food supply. Archives Néerlandaises de Zoologie 10: 171-239. 
This unfinished manuscript by Jan Verweij has been made available through Wader Study 124(1) at http://www.waderstudygroup.org/article/9294

doi:10.18194/ws.00066

This document has been drafted in the 1920s and 1930s by Jan Verweij and is made available in 2017 by the International Wader Study Group (IWSG) as a supplement to Wader Study 124(1) which can be accessed at: http://www.waderstudygroup.org/publications/wader-study/waderstudy-volume124/waderstudy-volume-124-issue-1/.

An introduction to the unfinished manuscript by Gerhard C. Cadée can also be found at above mentioned source.

\title{
Pair formation in the Lapwing, including its polygamy
}

\author{
J. Verwey \\ Zoological Station, Den Helder
}

Contents

Introduction

First Part: Account of the formation of couples, with a description of notes and movements

1. The Territory

2. The Song Flight

3. The nest-building Ceremony
a. Skipping and Scraping
b. Stick-throwing and nest-building

4. Fighting

5. Copulation and stiff attitude

a. Copulation

b. The male's stiff attitude

6. Sounds

7. Summary

Second Part: Polygamy in the Lapwing

1. Diary notes

2. Discussion

Literature 


\section{Introduction}

In biology, in consequence of the complexity of organic structure and the great variety of detail, an enormous amount of simple observation and description are required; but no one supposes that this is the whole or (even) the most important part of science of life (J.T. Cunningham (1928) in Modern Biology).

The observations which follow below were chiefly made in the spring and early summer of the years 1925, 1926 and 1927 in one of the polders near Noordwijk aan Zee, Holland.

Owing to lack of time and an absence of four years from Holland they were not worked out. In 1932 an opportunity presented itself to continue the observations near Den Helder and in the polder Waalenburg in the island of Texel, so that they could be completed in some, and compared with those from another place in other instances. The paper was made more or less ready for publication that year, but was not actually published, as I hoped to add two more chapters to it: one on the roles of the male and female in breeding and the care for the young in Limicolae, and one on the question of bigamy in birds in general. I studied part of the ornithological literature in this connection, but had to stop the work for want of time. In 1939 my friend Kluyver, Wageningen, urged me to publish the paper. I resolved to do so and Prof. A.E.H. Swaen, Amsterdam, to whom I owe many thanks for his help and interest, revised the English. When he was ready I completed the paper in several respects, but, again, could not resolve publishing it, as I much regretted its incompleteness as to the two chapters mentioned. In 1940 Rinkel's paper on the lapwing appeared, followed in 1941 by Brunhilde Laven's paper. Again, in the summer of 1941, Kluyver urged me not to wait any longer now and to publish the paper, changing as little in it as could be brought in agreement with the appearance of the two papers mentioned. On reading Rinkel's and Brunhilde Laven's studies I came to the conclusion that it still would be worthwhile to give my own paper, but only if I should fully deal with the contents of both other papers. So I greatly rewrote the first part of my manuscript, whereas the second remained largely unchanged. It is finally published after a lapse of some 15 years and, were it not for Kluyver, it would probably not have been given for another 15 years. From this fact the thanks I owe him may be judged.

I began my observations a year after having studied the breeding time behaviour of grey herons (Ardea cinerea L.) in some detail. These observations had revealed some interesting particulars concerning the polygamous inclinations of this species. After having found that the lapwing (Vanellus vanellus) would be a very thankful object for such studies I resolved to study it in the same manner, hoping that a comparison of the sexual life of grey heron and lapwing would yield interesting results. It soon became evident that polygamy plays a much more important role in the lapwing than in the grey heron. And as we can say that the lapwing is a typically monogamous species not the least interesting side of the whole subject was to me the continuous comparison during my work of the lapwing and that other biologically so interesting organism: man. I think my observations distinctly show what a large part of our sexual behaviour rests on the same instinctive base as that of the lapwing; man and lapwing show the same instinctive jealousy of male and female when love is concerned; both may under certain conditions, when opportunity offers itself, become disloyal to their true husband; but the most striking point is that in lapwings - as in man the female may subject herself to the disloyal male, whereas the male himself does not permit the female to behave in a like manner. One has only to compare the sexual life of the lapwings given below with that of Mohammedans to understand what I mean. 
This paper is concerned solely with the lapwing's sexual life and does not give any observations on other aspects of the birds life history, such as moult, migration, social conduct, its relations with its animate, plant and non-organic environment, its sense perceptions, etc. But also the birds' sexual life is dealt with incompletely only. Indeed no more than pair formation is dealt with. Such important parts as egg laying, incubation, care of the young and the up growth of the latter are omitted and so are all courtship activities to be seen fairly regularly in this species outside the mating season, at least in autumn. The latter subject must be of special interest in view of Lack's recent observation on the autumn display of the black cock, which is aggressive towards other males, but where display is not directed against a female. No details can, also, be given in the so important subject of sex recognition and of recognition of individual birds, and in other respects too this study is far from exhausting. I should also have liked - as I did in my paper in on the grey heron - to compare the facts found with those observed in other species of birds, wherever this seemed advantageous, but to my great regret here again I had to refrain from it for want of time. Part of such a comparison has been made, however, where polygamy is concerned, and I have further added a short comparison of the courtship activities or rather the display actions in those species of Limicolae, which have been fuller investigated in this connection up till now. It seems worthwhile for one well acquainted with the subject to make a fuller and more detailed comparison, now so many fine observations are gradually pouring in.

The lapwing has been the subject of more or less detailed study by a number of ornithologists. Their publications range from rather extensive ones, covering one or more sides of the birds life history, to very small notes. They are only dealt with in this paper in so far they are directly concerned and at the same time of sufficient interest in connection with my own observations. Those papers or notes which did contain details on the matter dealt with, but seemed not of sufficient interest to be quoted in the text are mentioned in the list of literature for the sake of completeness.

Some of the more important contributions are here mentioned apart. Selous, the unrivaled observer of birds, dealt with the bird in a paper in the Zoologist for 1902 and his observations were - somewhat changed - again given in a chapter in Bird Life Glimpses (1905). Some of the observations were used again in a paper on the origin of the social antics and courtship displays of birds in the Zoologist for 1912 and in a paper of 1914, p. 222-223. As usual he gave his observations as diary notes and though they are not very important, as they are apparently based on only 7 days observing, the different activities can easily be recognized from his description. Brock gave a short, but excellent account of the lapwing's life history during breeding time in the Zoologist for 1911. Especially his descriptions of the different activities, though short, are very good. His conclusions on me make the impression, however, of having now and then been made a little too soon, generalized too much. Miss Haviland's Notes on the courtship of the lapwing are of little value. Her remarks against Selous are chiefly concerned with the latter's theory on the evolution of nest-building. Selous' reply is given in his paper of 1916; it is certainly worth reading, even for those, who, like myself, have some aversion to evolutionary theories. Howard dealt with the bird in an excellent way in his Territory in Bird Life, describing the formation of territories. There is also a paper of Brown, with the lapwing as its special subject. It is superficial, not to say bad. Rinkel, in a paper which concerns also other parts of the bird's life history, deals rather extensively with the lapwing's courtship activities. His text is accompanied by clear figures and some very fine photographs. The descriptions of the activities are somewhat poor and his conclusions not always even logical, but the paper contains a great number of valuable data. Brunhilde 
Laven's paper, finally, which is also concerned, except with courtship, with several other sides of the birds behaviour, especially excels in clear and detailed description. It will be seen from my text that most of her descriptions of the different activities were fuller than my own, so that I often cite her. Most valuable, too, is her ethological interest, which makes it possible for her to deepen the contents of the paper. Probably as a result of her giving much time to full descriptions she apparently somewhat neglected the normal sequence of some activities and probably as a result of her studying so few birds she comes to more or less overlooking the importance of the territory in the lapwing's life. But such omissions of hers and her predecessors were of value, as they drew my attention to points, which apparently can easily be overlooked, and which I therefore could stress at the right time. Of course there are a number of smaller notes on the lapwing in scientific and popular accounts. They are mentioned when containing points of interest.

The observations cited below were for a good deal made possible by the plumage difference between male and female lapwing and the differences between the plumages of different females. Plumage differences between different males are mostly so slight that they were of hardly any use to me.

The male lapwing in full breeding dress has the crown, lores, patch in front of and below the eyes, a band across the ear coverts and chin and throat deep glossy black. This black contrasts strongly with the pure white of superciliary stripe and cheeks. Early in spring (March, first half of April, perhaps also later) some males, I suppose one year old birds, have the chin and throat still partially white and may therefore be taken for females; such males on the whole are rather rare, however, and they can be easily recognized as such when one has become familiar with the differences in behaviour between male and female. The wings in the male are broader than in the old female, but this seems not to hold for the one year old males. Generally speaking, the males haven longer crest feathers and are more beautifully coloured, but all these criteria were little made use of. In fact, the difficulty is not to distinguish between males and females, as their behaviour shows this very soon, but to differentiate the different specimens and as to the males this was rarely possible for me. Much help is given through the fact, however, that they adhere so strongly to a definite place, be it their territory or a special stance within the latter.

The female lapwing in breeding dress differs rather much from the male, as crown, throat and breast are not jet-black as in the male and the strong contrast between white and black in the head is therefore wanting. There is great individual difference, however, between the females inter se, as the number of feathers they moult in spring is very variable; whereas some have the chin and throat - when seen at some distance - nearly white, others have them intermixed with such a number of black feathers that the contours of the dark parts are the same as in the male. Thus there are male-like females with very dark crown, throat and chin, very light ones, with the throat nearly wholly white, and intermediate birds. These differences were used for identification of different females.

The observations near Noordwijk were made with 8 and 18 times enlarging Hensoldt glasses, those of 1932 with 8 times Zeiss binocular. I did not use some special hiding place, as the birds are not at all shy and after some time even grow quite accustomed to the observer. Thus the work is much facilitated when compared with that of a shyer bird. Not using a hiding place has the great advantage of superviewing the whole of the surroundings in a far better 
way than from a hide. Especially when observing an aerial bird as the lapwing in breeding time this has great advantages.

Before entering on my subject definitely I want to make some restriction as to its real value. In making such observations as are quoted below we always make the same mistake. Finding out that some happenings are of rather regular occurrence and therefore can be formulated as rules we are always inclined to overlook the fact that the animal we are studying is much less schematic than our mind and that it may every moment change its behaviour in quite unexpected way. For instance it is a rule that the nuptial flight of the lapwing consists of a number of distinct parts, following each other in one and the same order and that it is not displayed beyond the boundaries of the territory. But though this may hold good under many circumstances we constantly see exceptions to such rules and the variation in the behaviour described below is therefore much greater than a description would lead us to believe.

A second difficulty, of course, is that the actions follow each other in a rapid succession and that, therefore, it is neither easy to describe them fully and not to forget details, nor to give their right sequence and to interpret them rightly. As to the forgetting of details, this lay also at hand and indeed was important, because so much time had elapsed between the field work and the finishing of the writing. On the other hand, just because this paper appears so late, other papers have in the mean time appeared on the same subject, what had the advantage that I was able to compare my own observations and conclusions with those of my predecessors, and thus to eliminate a number of errors and inaccuracies of others as well as of myself. Especially Brunhilde Laven clearly showed me my own omissions, the greatest of which was that I have under estimated and greatly overlooked the gradual development within the pairing season of the series of nest-building and other activities. Besides, a great many minor details I had insufficiently realized came to light. I have everywhere tried to make clear where such was the case and have done the descriptions of my predecessors justice wherever this seemed necessary. Nowhere do I make use of their descriptions or ideas without clearly stating so. The paper as a result became less short, but also more complete. 


\section{First Part - Account of the formation of pairs, with a description of notes and movements}

The first thing for our lapwing breeding birds to do after their arrival with us in spring is the establishment of males, which therefore give up their social life within the flock, in definite parts of the breeding grounds. These parts are kept free from other males and in that way constitute their territory. Such a part is small, generally not exceeding $100 \times 100$ metres. The formation of a territory and the line of its boundaries can be recognized from the song flight of the male, which is chiefly performed within the territorial limits. As the flight is one of the outlets for the male's sexual excitement it is shown now and again between feeding, plumage dressing etc., but especially when another male approaches the territory, as the flight is used then to encounter the latter. For from the moment the bird has staked out his territory all male friends from the flock become rivals in so far as territory is concerned. Invaders, refusing to depart, are combated on the wing, viz, by wing beats. Two such combating males form the pairs of lapwings hanging in the air, which are so distinctive for all lapwing breeding grounds in spring and early summer. They, too help to show us the territorial boundaries.

During the first days or even weeks, especially when we have a cold spring, the males do not remain in their territory the whole day, but leave it now and then for a longer or shorter time, the duration depending on the air temperature of the days in question. During their absence from the territory they join their mates, who less than half an hour ago still were severely attacked, and from rivals become companions again. The parts of the ground chosen for such flocking may be more favourite for feeding by their drier or more sheltered position or for some other reason; but my evidence for this rests on a very slight base, see below under Territory.

The females seem to give up their social life a little later than the males. My own observations on this point were only very few and not made before 1932, when I had been influenced by Brocks views already, but I think the somewhat late appearance of the females on the territories occurs in the majority of cases. Rinkel mentions a difference of 1-2 days, but as a rule, I think, it is more.

The result is that many territories have been staked out by the males when the females are still free. During that period a bird which I take to be a female may be seen to fly around high in the air, continually calling "kee-a-weet", repeated at intervals in a rather monotonous way. I think this flying around represents the female's first visit to the breeding grounds. I believe as a result of its appearance the males become stimulated and begin flying their song flights; the overflying of a single calling bird may cause many males to start song flying. Thus the females can discern in some few moments all about territories and their inhabitants. I have never seen such females actually come down, because my observations on the very first happenings have been very few. But I may conclude from other observations that they do so in the neighbourhood of a male, whereupon the latter, having finished his song flight, begins sooner or later the procedure I shall for a moment call the nesting ceremony. This ceremony consisting of two, or rather three, parts, has a greatly attractive force on the female, for it is clear that she cannot resist approaching the male. She begins participating in his nesting activities then. As soon as this is the case there is a good chance that they will remain together and thus form a couple. The remarkable nesting action, which is also, but not much, used as an outlet for sexual excitement when a female is absent, is neither a pre- nor a postcopulating movement, but its biological significance lies in the fact that it brings the birds 
closely together, so that mating may follow. After male and female thus have become a couple copulations may be seen to take place several or even many times a day. Most of the time copulating follows the song flight or the aerial fighting of the male, the male descending directly from the air on the female's back. Copulating is often followed by "nesting", when again the male tries to allure the female.

This, then, is briefly the way in which the couples are formed. Before going into the matter of polygamy in more detail the chief points of this general pairing biology need further description now.

\section{The Territory.}

The male, which leaves his flock and establishes himself in a certain part of the breeding area, behaves differently from when living his social life in that he keeps his ground free from other males. But also when other males are absent and when he is not performing his nesting ceremony, flying his song flight, or the like, he is a different bird. I did not realize what this difference contained until I read Rinkel's paper. "He stands high and looks around him. In fact, he makes the impression of supervising his ground and the best word for his posture would be imposing attitude. The bird thereby may possess what Brock unintentionally has called his usual stance, a place from where the surroundings are constantly kept under view. Rinkel also mentions it, calling it the bird's headquarters (hoofdkwartier), a term presumably taken from Howard, who denotes as such the tree or branch which is used as a basis by male territorial songbirds when making themselves conspicuous by their song. It is indeed quite the same place. Howard assumed that the chief reason for the birds to choose such a place is to make themselves conspicuous and no one has since doubted the biological function of the behaviour. It is interesting to note, however, that the choice of this stance in the lapwing apparently may depend on the place from where danger is to be expected, for some of the males I studied preferred to make it just in front of me, in my eyes for no other reason than that they wanted to watch me. This means that to the bird the headquarters may mean a place from where the surroundings can well be kept under view and this is only logical. For if the bird instinctively would be forced to make itself conspicuous it certainly does not do so because it knows that it is better seen by others. It is certain, however, that the development of an instinct to seek outstanding places must be accompanied by the strengthening of the instinct constantly to be on the lookout for intruders, and the choice of the headquarters may therefore be assumed to be governed in the first place by its value as a post for watching. Tinbergen (1939, p. 11, see also p. 20) comes to quite a similar conclusion in the case of the snow bunting (Plectrophenax nivalis and also cites Michener's study of the mockingbird in this respect). The Ryves, in their study of the corn bunting come too the conclusions $(1939$, p.7) that the essential condition for the headquarters in this species is that it allows the male to command a view of the nest site or sites. All this can only hold, of course, for such territorial birds as possess true headquarters within a somewhat large territory not for colonial birds, in which headquarters and territory are one. It should be added that the lapwing's stance clearly results from the birds adhering to some definite place through mere habit formation. It may therefore easily develop, but no less easily be replaced by another. Its fixation is a very partial one only and this too is natural, because it is a marvel that the bird, having a whole meadow at its disposition, binds itself to one and the same spot for any period of time. The same doubtless holds for other species, compare e.g. Tinbergen 1939, p. 20. 
Fine descriptions of the way in which such males gradually give up their life within the flock, to change it for their territorial life have been given by Brock and Howard. Especially the latter's description (p.58-61) is excellent. "There is a water meadow with which I am familiar, where large numbers resort annually for the purpose of procreation. Here they begin to arrive towards the end of February, and at first collect in a small flock at one end of the meadow. A male, here and there, can then be seen to break away from the flock, and to establish itself in a definite position upon the unoccupied portion of the ground, where it remains isolated from its companions. Others do likewise until the greater part of the meadow is divided into territories. Six of these territories I kept under observation for approximately two months in the year 1915. The occupant of the one marked no. 6 upon the 1915 plan was a lame bird, a fortunate occurrence as it enabled me to follow its movements with some accuracy; and though it maintained its position for some weeks it ultimately disappeared, as a result, I believe, of the persistent attacks of neighbouring males. The behaviour of the males during the first fortnight or so after they broke away from the flock was interesting. Though they retired to their territories and remained in them for the greater part of their time, yet it was only by degrees that they finally severed their connection with the flock, for so long as a nucleus of a flock remained, so long were they liable to desert their territories temporarily and to rejoin their companions". Howard then proceeds, calling attention to the remarkable change in behaviour of the male who leaves the flock. "The males spent part of their time in their respective territories and part with the flock, so long as it remained in existence. When a male was in its territory it avoided companions and was openly hostile to intruders; when it was with the flock it wandered about with companions in search of food. The contrast between the two modes of behaviour was very marked, and it was evident that the gregarious instinct was gradually yielding its position of importance to the new factor - the territory. If there had been no flock, if a few solitary individuals had appeared here and there and had established themselves in different parts of the meadow, one would have no definite evidence of the strength of the impulse in the male to seek a position of its own, one could only have argued from the general fact of males flocking in the winter and isolating themselves in spring that something more than accident was required to explain so radical a change. But since the birds returned in a flock to the ground upon which they intended to breed, and since the flock occupied temporarily part of the ground whilst the partitioning of the remainder was still proceeding, it was possible to gauge the strength of the impulse, which was forcing the males to isolate themselves in particular areas of ground, by comparing it with the impulse to accompany the flock - and the measure of its intensity was the rapidity with which the latter impulse yielded its position of importance".

I remarked already that especially during the beginning of the breeding season the male may leave his territory for hours at a time and also that the females seem to give up their social life a little later than the males. It would probably be more right to say that to awake the sexual instincts of the females the air temperature must be a little higher. On cold days they incline sooner than the males towards leaving the territories for hours or even days at a time. The result is that many territories have been staked out by the males when the females are still free. The interpretation of my few observations on this point has however, been influenced by Brock's views, which were already known to me when I made these observations. "If birds are disturbed at this early season the looseness of their connection with the nesting ground is shown by their tendency to desert it - a tendency equally apparent in the birds still flocked, and in those individuals which have separated from their fellows and commenced their spring activities". "The field thus deserted by the birds may remain tenantless for hours, frequently until the dusk of evening. Apart from outside disturbance, at frequent intervals the birds leave 
the grounds of their own accord, particularly during early afternoon, and until mid-March, or even later, this phenomenon may continue, more especially in the event of cold or stormy weather". "A feature of early March is the high proportion of males to females present, a discrepancy largely due to the fact of the weaker attachment of the females at that season to the nesting grounds". Miss Haviland's observations on this matter (p. 220-222) point in quite the same direction. My own observations were made in the polder Waalenburg, Texel, in the spring of 1932. I here saw that the first male lapwings, which had established themselves on the breeding grounds, now and then disappeared to another part of the polder. I did not certainly find out where the birds after their disappearance went to. They flew in the direction of the dunes, however, and as on the somewhat higher and drier meadows just along the dunes lapwings - and especially female lapwings which were largely missing in the polder together with black-headed and common gulls (Larus ridibundus L. and L. canus L.) parasitizing on them, were busily feeding, I assume that my birds in Waalenburg left their territories for going to feed on drier ground. These observations taken together one strongly gets the impression that at least in the earlier part of the season optimal feeding grounds are difficult to combine with optimal grounds for breeding. Since Howard's studies we know the same for part of the territorial songbirds which stake out their territory early in the year, e.g. the buntings. They regularly resort for feeding to other than the nesting grounds. As to the lapwing, it doubtless is due to the same fact (to wit, that many grounds are not optimal for feeding in spring) that some polders, which are inhabited by large numbers of lapwings outside the breeding season (at least in autumn and winter), are quite devoid of them as a breeding species.

According to the descriptions of Brock and Brunhilde Laven the male lapwings, before leaving the flock to establish a territory, already may show signs of dawning sexual instincts, evinced by a slight increase of jealousy. "They make sudden unprovoked attacks on each other, which attacks, however, are only momentary and of slight extent". Brunhilde Laven describes how the birds within the flock during this period avoid each other's company as much as possible, and when coming in each other's neighbourhood may chase one another and show some quarrelling. The males would also show inclination to stand alone, though not on their later territories, "vielmehr zeigte sich bei ihnen nur die Neigung zum Einzelgangertum an irgendeiner Stelle". Personally, I am not quite convinced that Brunhilde Laven's observations must be interpreted to represent this quite gradual change from social to territorial bird, and my reason is that lapwings show much fighting also outside the breeding season, and that the conclusions of BrunhildeLaven on me make the impression of being based on too few observations. On the other hand Tinbergen $(1939$, p. 8) too mentions an increased quarrelling in snow bunting flocks in spring before their splitting up; possibly there are other similar observations for more species. As soon, however, as the male has taken up his definite position in the field it is otherwise: fighting becomes an important occupation. Rinkel says that during the few first days fights are rare, because there still are so few other males to fight with. This holds for the early males only, of course, not for the later ones. Gradually, however, as more males join in, a constant fighting takes place to defend the integrity of the ground taken into possession. In fact, one sees them fighting with short intervals practically the whole long day at the slightest inducement. They no longer leave their territories now, but sing, court and fight. This fighting, which is so important in connection with the maintenance of the territory, should be dealt with more fully, but I omit its treatment here, because I prefer giving it a special chapter (chapter 3). The same holds for the song flight. Though it is of particular importance in connection with territory its treatment here would had me too far away from the territory itself, and the reader is therefore referred 
to the next chapter. Before going on I should add that it was especially by observing the fighting that - just as in other territorial birds - the boundaries of the territory were in most cases identified. Further, to take away all later misunderstanding, I should also add that these boundaries are not quite fixed, but more or less changeable. This becomes best apparent when a new male stakes out a territory on ground already taken in possession by other males, when all neighbouring limits may undergo some change, but probably the limits change somewhat from week to week and much depends on the state of activity of the male in question and his neighbours. All this holds in just the same way for the territories of birds of other groups, but few details in this direction have been published: see Tinbergen, 1939 p. 15-18, for the snow bunting; Huxley, 1934 for the Coot (Fulica atra) and others. This holds in just the same way for the territories of species of birds of other groups, but few details in this direction have been published. It becomes best apparent from the arrival of a new bird, which must be less obvious than in a bird like the lapwing.

There is much difference in the size of the territory. That of a male I studied near Den Helder at first measured more than $150 \times 120=18,000 \mathrm{~m}^{2}$, but such a large territory nearly always decreases in size later on. In places where many pairs nest closely together each territory may cover a surface of no more than some $2000-3000 \mathrm{~m}^{2}$, see below. I reproduce two maps of myself as an illustration. Howard's maps page 58-59, and Rinkel's map, Fig. 9 - II, also well illustrate such differences: the largest territory figured by Howard measures some 6300, the smallest not much more than $2000 \mathrm{~m}^{2}$, whereas these values for the territories figured by Rinkel are something in the neighbourhood of 4800 and $1600 \mathrm{~m}^{2}$.I think, some $4000 \mathrm{~m}^{2}$ may be a good mean for the surface of a territory. Nicholson in his Report on the Lapwing Habitat Inquiry, 1937, states on page 215: "Density of population was also not investigated, but it may be useful to record that in $1930 \mathrm{~A}$.W. Boyd found an average of 18 breeding pairs of Lapwings to 1,000 acres of typical N. Cheshire farmland". It is clear from this statement that there is question here of the land taken as a whole, that neighbouring lands with and without lapwings are included, and that Boyd does not mean to say that the territories of 18 pairs cover an area of 1000 acres. For, as one acre is equivalent to $4047 \mathrm{~m}^{2}$, each pair would possess some $225,000 \mathrm{~m}^{2}$ and this is more than twenty times the mean we really find for the size of the territory.

The form of the territory, too, may show much difference. Howard's two plans give a fine example of the strange contour lines territories may show. One of the territories of his 1915map is a rectangle of about $120 \times 30 \mathrm{~m}$, another, of his 1916-map, is an equilateral triangle with sides of 70-75 m. Strange contour lines are also found in some of the territories on my map for the area of observations near Den Helder in 1932.

More important than size and form as such is the cause of their development: how do such different territories come into existence? I deal with the size first. A pair of lapwings without neighbours has to deal with two requirements in so far territory is concerned: nesting and searching for food. At first sight it may not seem that there is a good reason to separate these two, as we have grown accustomed to the fact that the lapwing breeds on its feeding grounds. We already saw, however, that some grounds and even whole polders, though they are much resorted to by the birds in the colder season, are devoid of them in breeding time.

Moreover, I described those lapwings which, apparently for feeding, left their territorial ground for quite a different part of the polder near the dunes, a different polder in fact, lying some 2-3 kms away. Now, somewhat later in the season these same birds of Waalenburg had 
mated and began to lay their eggs, and it was interesting to see now how one single pair, which I kept under observation on April 3rd, resorted for feeding to a somewhat higher part of their territory, whereas the nest was in a lower part, perhaps some 50 to $80 \mathrm{~m}$ away. This caused the birds to fly or walk from the nesting to the feeding place and vice versa many times a morning. Here then I had a fine instance of feeding and nesting taking place at the two extremities of a long territory and there could be little doubt that the size of the latter was due to this cause. It is only natural then that the size of the territory must result form a compromise between the want of a favourable nesting and a favourable feeding ground and whereas the want of food probably would call for a larger area the nesting ground should not be too large, as supervision may become too difficult then, a supposition already expressed by Tinbergen (1939, p.20). The size, therefore, will never be more than perhaps 20,000 to $30,000 \mathrm{~m}^{2}$ at the utmost, and the limit for smallness must depend on the richness of the territory as a feeding ground. It should be stressed that in discussions on the biological function of territory mention is often made of the food conditions for the young birds, but here the feeding conditions of the adult themselves were apparently of distinct interest.

As to the form, the territory of a pair not hindered by neighbours will be more or less circular when it makes part of a single large meadow or more or less square or somewhat oblong when straight ditches succeed in influencing the birds. In the last mentioned case, which is so often realized in our Dutch polders, we may also see that the birds do not bother about ditches or even rather broad waters, which we would expect to influence them. This fact is observed in just the same way by Rinkel.

Till so far size and form when the birds have ample space at their disposition. As soon as they get neighbours, however, the territorial limits may become largely changed, and in many cases the size of the territory undergoes rapid diminution. A new male, establishing himself between others, may gradually succeed in gaining ground. Rinkel says that if such a male succeeds in establishing himself he may also succeed in enlarging, his ground till he has little less than his neighbours. These, of course, have then lost part of theirs.

To this there is a limit, of course. One never sees territories of say 1,200 $\mathrm{m}^{2}$. Howard and Huxley (Huxley, 1934, p. 274-275) have come to the conclusion that aggressiveness in the coot increases as the size of the territory decreases, and Tinbergen (1939, p. 20 and 70) finds that the pugnacity of the male snow buntings grows stronger and stronger as their territories grow smaller. Moreover, however, a purely ecological factor may come to help. If the territories become so crowded newcomers find bad ecological conditions even on grounds rich in food, and they may therefore refrain from trying to settle. I think this must be a factor of some importance too.

Favourable breeding grounds may be inhabited by such large numbers of birds that what could be (and perhaps originally was) one single territory becomes a daught-board of many, the one still smaller than the other. N. Tinbergen tells me he saw at the well known bird sanctuary De Beer near the Hook of Holland 10 lapwing's nests on an area of about 24,000 $\mathrm{m}^{2}$, so that the maximum size of the average territory would have been $2,400 \mathrm{~m}^{2}$. It is quite possible, however, that some of the males had more than one wife and in that case the average size of the territories would have been larger. Rinkel's map, fig. 9 - II, contains some territories of about $1,600 \mathrm{~m}^{2}$, but I can hardly imagine they remained of this small size also later in spring. Not only will the territories, with the arrival of new males, become smaller, 
but their contour lines will incline to become more complicated, because each bird sticks to particular parts of his former larger area.

An interesting point is formed by the shifting of the territorial boundaries. This may take place as long as there are no eggs, after the birds have just established themselves, as well as later, after the clutch has been taken by man or some animal. Brock already states the limits of the ground claimed by each male are of very vague definition: "and appear to be modified with the advance of the seasons or with the little group of scrapes with which the male interests himself, since a group formed in the earlier days may be deserted later in favour of a fresh set at some distance". To mention here the advance of the season is right, to mention the scrapes, however, is merely stating in another way that the territory is shifting. Rinkel's map, fig. 9 - II, gives a fine instance of the shifting of the limits of some neighbouring territories as a result of the disappearance of the owner of one of them. In those cases where I could state such shifting it was probably always the female that took the initiative, the male being more conservative in this respect. He establishes a territory and after some time a female comes. This female may begin to frequent a part of the breeding grounds lying somewhat outside the true territory (assuming that it is not within the territory of another male). The male will then follow here in the beginning flying back to his old territory every time, but gradually diminishing these visits, until he has made the neighbouring ground his home.

Successive removals may shift the territory over a distance of some hundred metres, but it should be added that in these cases a male with more than one female was concerned and it may be that the extent of the change was partly due to the jealousy of the rival females. On the other hand, the distance over which the territory may be transplaced between two broods can probably be much greater still. The country people near Noordwijk knew quite well that a small number of lapwings regularly removed from the polders to the neighbouring dunes somewhat later in the breeding season. It was generally assumed by these people that the dunes were more quiet than the polders with their many egg searchers, in which they may have been right, but I think it also possible that the dunes, with the gradual rising of air temperature in early summer, enjoyed a richer insect life than the wetter meadows, the grass of which, too, became longer in summer.

An interesting point in connection with the shifting of the territory under the influence of the female is the question in how far the female is "acquainted" with the limits of her mate's territory. In the above instances she does not bother about limits, takes neighbouring ground, and only because the male follows her does she remain within the male territory. I borrow from Tinbergen's paper (1939, p. 62-65) that Dewar (1920) and Nice (1936) quote similar cases for the blackbird and song sparrow respectively. Further that Brock observed a female willow warbler making her nest outside the male territory, whereas Tinbergen (p. 31) gives instances of the female snow bunting doing the same. There are also some cases (p. 27) of females leading the male astray to fight outside the limits of his territory. "In all of these cases it is impossible to determine whether the female actually did not know the male's exact boundaries or merely neglected them. They suffice, however, to show that the female often does not show such a rigid connection with the territory as the male" (Tinbergen 1939, p. 64). It is difficult to imagine, however, what means the male would have to inform the female about the limits, except in cases where she observes him fighting other males, there, but probably there only, must she easily understand what is foreign ground also to her. 
Before finishing this chapter I want to add a few words on account of Brunhilde Laven's criticism of Rinkel's paper where he is concerned with the lapwing's territory. She assumes Rinkel is mistaken when he gives a map with the territorial limits of his birds, also when he is speaking about real territories and even states he recognizes the territorial limits from the song flight and fighting of the males. The male's polygamy, too, according to her, would pledge against the existence of true territorial limits. "Hier ist es eher geboten, mit Tinbergen (1939) von sexuellen Einflussbereichen des (male) zu sprechen." Rinkel is not mistaken, however. If Brunhilde Laven means to say -as she more or less does on page 12 of her paper - that it is difficult to give exact limits for the territory she is right and in agreement with Rinkel, who stresses the fact that the limits are not rigid and can easily change on the arrival of a new male. If she means to deny the existence of rather well defined territories, however, (probably not less well defined than those of the ringed plover and songbirds, mentioned as instances by her) her birds failed to show her all they would have been able to. I should add once more that for the relation between territo ry the song flight and fighting the reader is referred to chapters 2 and 3.

\section{The Song-flight.}

I stated in the foregoing account that especially the song flight is of particular importance in relation to territory. As it is by far the most conspicuous ceremony the lapwing possesses it is the first activity to be described below.

The male, staying on the ground feeding or feather preening, or supervising his surroundings, lies at once away, in a straight line close above the ground. He does not use his wings in the ordinary manner, but flaps them deeply in a slow tempo, so that a very conspicuous flying results. Brock rightly calls it owl-like. After some seconds, when the bird may have moved about 10-20 metres, he begins beating his wings more rapidly, so. that after some seconds he flies very fast. At the same time he throws himself now on the left, then again on the right side, whereby with each toppling of the body the direction of the flight is changed in such a manner that a zigzag flying results. This was my own interpretation of what I saw, but Brunhilde Laven, who had at her disposition slow motion pictures made by Laven states (see fig. 1) that when the bird's underside is directed to the left the bird's course makes a curvature to the right and when the underside is directed to the right the course makes a curvature to the left. According to her, therefore, as a result of the toppling of the body, a curved course develops, imitating a zigzag one. The extreme left and right points of the curved course would be found just between two topplings. This is not so, however. The moment the body topples the course is abruptly changed, so that the zigzag strokes are separated by toppling at their end, not halfway. At the same time, however, she is also right. For each zigzag stroke is not straight, but somewhat curved, because the bird, when flying on one side, evidently cannot fly straight stretches. This latter fact, which can well be seen in the field, was not seen by me before Brunhilde Laven's paper had drawn my attention to it.

Brunhilde Laven further states that each successive toppling occurs after 4-5 wing strokes and that the bird's position in the air makes fully $90^{\circ}$ with the normal one. The latter conclusion I should not have reached from my own observations; as to the number of wing strokes between two successive topplings, this may apparently show great variation, just as any other part of the song flight to be described below. As a result the zigzag strokes may be of very different length, possibly from 10 to $30 \mathrm{~m}$. 
During this part of the flight a very characteristic buzzing (Huxley) or humming sounds (Brock) may be produced, sounding like "woo - woo - woo - woo" etc. It is called "zwoegen" by the Dutch, "Wuchteln" by the Germans. This sound is said to be produced by the outer flight feathers beating the air and this is most probably the true explanation, as the female, which has somewhat different, narrower, outer flight feathers never makes the sound. Huxley (1912) has supposed that the lapwing "can produce the buzzing sound at will, apparently by alternating the angle at which the feathers strike the air". There is, I think, little reason to suppose so. Observation teaches us that the sound is only produced after the bird has reached a certain velocity and that it develops and diminishes gradually when the bird rises or lowers its speed. Furthermore, Bahr (1907), who studied the well known bleating of the Common Snipe experimentally, makes it probable that this sound is bound to a certain velocity of the bird, according to him some 20 miles an hour. According to him the velocity should neither be too small, nor too great. Brunhilde Laven supposes that the sound is produced by the wings as a result of the abnormal sideways position of the bird in the air during the zigzag flying and it may well be that she is right and that, apart from the velocity, the position of the bird too is important. I believe, however, that the sound may develop before the zig-zag flying and if this would be right the sound depends on the velocity obtained and not on the bird's position in the air. In the new edition of Naumann's Naturgeschichte der Vögel Mitteleuropas (Vol. 8, footnote page 9) it is stated dass das Wuchteln von dem Gaukelflüge ganz unabhangig ist" and also may take place when the bird is flying straight stretches. This may be right, but I fear that the ordinary sound produced by the wings may have been taken here for the buzzing sound, as the production of the latter when the bird is flying straight stretches must in any case be very rare. It would be attractive exactly to study the way in which the sound is produced just as closer experimental study of the snipe's bleating, which has never been made since Bahr wrote his paper, would certainly be worth the trouble. There is an observation of Stubbs (1912), apparently showing that in the snipe the drumming is not made when the bird sails down that part of its song flight in which the sound is normally produced with its belly upmost, as sometimes it may do.

After having covered a certain distance the male changes this zig-zag woo-flying into a short straight piece of flight again, which now is of very great speed. During this part of his flight he may utter the first syllables of his beautiful song, so well known to every nature lover. As this song is torn to pieces in my further description it should here first be given in its complete form. It runs as follows; for the sake of comparison I have added Naumann's, Brock's, Rinkel's and Brunhilde Laven's descriptions, further that of Reboussin (1911).

Reboussin calls this song "Cri du Vanneau male en amour, and adds: "(enjoué et en montant, plus rude et plus sourd que le reste)". But I fail to understand to what part of the song this remark applies, for I think it represents the full song. Therefore, I do not understand his further remark either: "Souvent, en descendant et pirouettant, il chante: Krioî, Kiritoi, toi".

\begin{tabular}{|c|c|c|c|}
\hline Naumann & $\begin{array}{l}\text { Chäh querkhoit } \\
\text { kiwitkiwitkiwit }\end{array}$ & $\begin{array}{l}\text { Kiuiht (laut, daher hört man in } \\
\text { bedeutender Entfernung oft nur dieses } \\
\text { Quiken deutlich) }\end{array}$ & \\
\hline Brock & $\begin{array}{l}\text { Whey (long drawn and } \\
\text { hoarse) }\end{array}$ & $\begin{array}{l}\text { Whey-willuchooee-willuch-willuch } \\
\text { (rapidly and staccato) }\end{array}$ & $\begin{array}{l}\text { cooce } \\
\text { (low, clear, } \\
\text { musical) }\end{array}$ \\
\hline Reboussin & Hvoê & Kiritoit-toît,toît & Hvoê \\
\hline
\end{tabular}


This unfinished manuscript by Jan Verweij has been made available through Wader Study 124(1) at http://www.waderstudygroup.org/article/9294

\begin{tabular}{|l|l|l|l|}
\hline Br.Laven & $\begin{array}{l}\text { Chä chuit (lang } \\
\text { gezogen, bisweilen } \\
\text { zweimal) }\end{array}$ & wit wit (hoh und scharf, auch 3-4 mal) & $\begin{array}{l}\text { Chiuwitt } \\
\text { (laut) }\end{array}$ \\
\hline Rinkel & $\begin{array}{l}\text { tsche-wie-e-wie } \\
\text { (hoarse) }\end{array}$ & wie-wie (long drawn) & $\begin{array}{l}\text { tsche-wie-e- } \\
\text { wieiet }\end{array}$ \\
\hline Verwey & $\begin{array}{l}\text { kee-oo-weet (or simply } \\
\text { oo-wiet not loud) }\end{array}$ & $\begin{array}{l}\text { kee-oo weet (loud, long drawn) } \\
\text { weet-weet (short, rapidly }\end{array}$ & $\begin{array}{l}\text { eeee-a-weet } \\
\text { (loud) }\end{array}$ \\
\hline
\end{tabular}

It follows from this that, generally speaking, the descriptions are similar, though in details there are some difference. These are partly due to mistakes however; Rinkel, for instance, gives the wie-wie as long drawn, whereas, on the contrary, it is short and rapid (also according to Brock and Brunhilde Laven).

As stated above the first part of this song, the introductory kee-oo-weet or oo-weet, is, uttered not very loudly during the straight piece of flight which closes (terminates) the zigzag flying. This sound may also be omitted, however, and I suppose that it represents one of the two "Chä chuit", mentioned as occurring sometimes only by Brunhilde Laven.

Up to and inclusive this short straight piece of flight which terminates the zigzag course the bird covers the whole distance close above the field or meadow. It now rises, often rather steeply, up to a height of some 10-20 m above the ground. I conclude from Brunhilde Laven's description that the last swift part of the horizontal flight so to speak may help to move the bird upward, for she says that "je höher das Tier in die Luft hinaufstösst, desto mehr verliert es an Fahrt", , but she also says:" Zum Ende des Anstiegs setzen die Flügelschläge aus und wenn der Endpunkt erreicht ist, fangt sich der Vogel auf, so dass er wieder in die Waagerechte kommt"2.

A short stretch of horizontal flying at the height reached by the steep rise ( a stretch of some 5-8 $\mathrm{m}$ long, some 10-20 $\mathrm{m}$ above the ground) now follows and the central part of (he song, the fine "kee-oo-weet-weet-weet" is produced during this higher flying, with a short pause between the first part and the rather high final "weet-weet". According to Rinkel the first part of the song is uttered during some slow wingstrokes, whereas the final weet-weet is uttered when the bird has lost nearly all its speed. The song is audible at a great distance and N.Tinbergen tells me he was often struck by the great force with which the bird throws its sounds away with jerks of its head. This is probably what Rinkel means when he states that the first syllables of the song are uttered with characteristic movements of the neck.

Brunhilde Laven says the first part of the song, the kee-oo-weet, is made during the steep rise and the last part, the weet-weet, during the horizontal part of the flight. In this she must be mistaken, however, the song, except the introductory first "oo-weet" or "kee-ooo-weet", being wholly uttered during the horizontal stretch of flying at some height, with a short pause between the (second)"kee-ooo-weet" and the final "weet-weet". She also suggests that the high horizontal part of the flight is so short, because the "weet-weet" is so short, but even if

${ }^{1}$ The higher the animal rises into the air, the more it loses its speed.

${ }^{2}$ At the end of the climb, the wing beats slow down, and when the highest point is reached, the bird returns to the horizontal position. 
the "weet-weet" were the only syllables given on this stretch it would be false to create the impression of such an absolute interdependence of song and flight.

She also states that small dives (kleine "Taucher"), which can also be absent, however, may be made during the horizontal flying and that this part of the flight terminates with a "nur leicht angedeuteter, nochmaliger, kleiner, schräger Anstieg"3. I do not know how this is to be combined with what Rinkel states about the small speed of the bird at the end of the horizontal stretch and with my own observations, according to which this high part is straight.

The steep dive downwards at the end of its horizontal part closes the song flight. It is very often made near the territorial limits. During this dive the bird makes his famous somersault. I myself have not succeeded in analysing what actually happens that moment. Broclc says "the performer, throws himself side-ways almost on his back, instantly recovering himself with a flurry of wings". Reboussin says "Sa façon de pirouetter n' est pas un mouvement de vis, mais un mouvement de vers à avers très rapide donnant l'illusion du tour complet"4.

Rinkel too stresses the point that no true turn is made; according to him the bird turns about $90^{\circ}$ around his longitudinal axis, first to one side, then back and to the other, then to resume his ordinary position again. If we realize that the zigzag flying male according to Brunhilde Laven's description already makes turns of $90^{\circ}$ to the left and right, Rinkel's assertion that the lapwing does not reach more than $90^{\circ} \mathrm{can}$ not be right. It is therefore valuable that Brunhilde Laven's description and figure (made after slowmotion pictures) leave no doubt that the bird may make one or even two whole turns around its longitudinal axis, or turn back in the opposite direction after having made half a turn, i.e. after having thrown itself on its back. The final eeeee-a-weet of the song is made during this dive and somersault; it is very loud and, still more so than the central part of the song, audible far away. According to Rinkel the last "weet" is uttered together with the resumption of the normal attitude by the tumbling bird. Brunhilde Laven says that the length and strength of the kee-oo-weet directs itself "ganz offensichtlich" to the length and violence of the dive, a fact of much interest in connection with the narrow connection between action and song. I suppose she may have somewhat been influenced by Laven's observations on the ringed plover, however.

One whole series of actions has been gone through and the bird may alight now. As a rule, however, the performance is repeated a number of times, so that every time the bird has made its final dive with tumble it turns back on its course and starts anew. The owl-like, slow, deep flapping, with which the first song flying begins, is however absent then, so that the bird after the tumble begins zigzagging at once, a fact stressed already by Brock. The bird therefore gives its full song flight when rising from the ground, not when repeating it. It should be stressed that the zigzagging precedes that part of the courtship flight which contains the song and is not its termination as Rinkel's description and Brunhilde Laven would make us believe.

Song flying may be of very long duration and consist of an endless number of single flights; I once timed an excited male who continued his flight for six minutes without interruption, compare the diary notes for 31 March, 1927; probably it may last longer still, Rinkel speaks about ten minutes. The song flight is only possessed by the male; in the female anything like

\footnotetext{
${ }^{3}$ only slightly indicated, repeated, smaller, more oblique rise

${ }^{4}$ His way of pirouette is not a screw movement, but a very fast to and fro movement giving the illusion of the complete turn.
} 
this flight is absent. The song flight is the chief outlet for the male's sexual excitement. We must express ourselves in this way, because we can clearly see that all kinds of excitement in spring bring forth this beautiful ceremony: the appearance or approach of either a female or a male, the fighting of other males or of the male himself, and perhaps most of all the song flying of other males. By this I do not mean to say of course, that the song flying does not start without influences.

The biological significance of the flight lies in the very first place in its importance in connection with the attracting of the female to the male and with the staking out of the territory.

It has, since Howard published his fine "Territory in bird life", gradually become common knowledge that all those birds for which the possession of a territory is essential for reproduction behave in a like manner in that the males (in Phalaropus the females) isolate themselves in spring and make themselves conspicuous. We already saw the lapwing do the same. Females are attracted to such males and thus pair formation may follow. As such advertising males are at the same time intolerant towards rivals, the latter are kept at a distance. It is probable that advertisement has a repelling effect on a new male, but this has never been proved. Tinbergen (1939, p. 17), however, gives proof for the snow bunting of the repelling effect of what he calls the ceremonial flight of the male. There is proof, however, of the attractive force of the "conspicuous" male on eager females, so that pair formation may follow. Making conspicuous may take place - in most cases from exposed headquarters - by movement or (and) sound. In songbirds we denote these sounds as their song, but any sound made under similar circumstances by other birds functionally may be called song as well, a view that his been expressed several times already, also by Howard himself (1920, p. 120). The harsh call with which the male grey heron attracts the female is, then, his song. Male birds of other species attract a female by movement only, the cormorant being a good example (Kortlandt, in litt). There are many species, however, which make themselves conspicuous by movement as well as sound and to this group all those species belong, which utter their song while flying or jumping up into the air, as some pipits, larks or warbles do, but also such birds as the pheasant, blackcock, grouse and ptarmigan. We find this combination of movement and sound also in the advertisement of Limicolae and what attracts attention most of all is that not only the song, but the flight as well, is an elaborate performance here, apparently as important as the song itself. This beautiful entity of song and flight in the lapwing is represented by what I have called his song flight and, judging by its analogous function in other species of birds, the latter may be assumed to have the function to bring the female to the male, or as Tinbergen (1939, p 79) still better puts it, to attract a mate from afar. It should be observed, however, that in the case of the lapwing (as in that of many other species) it is not easy directly to prove the song function of the song flight, i.e. its function to bring the female to the male territory and this for the following reason. The male grey heron, when longing for a female and posting himself on an old nest or on a branch, utters his harsh love call numerous times in succession up to the moment a female arrives. The very moment she joins him the male ceases uttering the sound. In case she disappears again he starts calling anew, but if then she returns to him he immediately ceases calling again. If she remains with him he stops calling, not to use his love call until the next spring. This clear connection between song and female is also found - though less outspoken -in some Sylviids enumerated by Howard (1920, p. 131-132), in the willow warbler, robin, song sparrow, (for literature see Tinbergen 1939, p. 77), and snow bunting (ibid, p. 24, 25-26, 77), in the cormorant (though here, as stated already, movement replaces song) and certainly in 
other species I am not acquainted with. In many other species, however, and the lapwing is one of them, this clear relation does not exist: the song does not stop immediately the female arrives, and singing may continue during the greater part of the breeding season. There is no reason, because of this fact, to consider the song to have a different function here, though there certainly will be some reason why in some birds it stops at mating, in other birds not. The sole argument we therefore have to consider the song flight of the lapwing the bird's song. i.e. the means to bring the female to the male territory, is that from analogy with other species.

In those species of birds in which the songs stops at the arrival of a mate and starts again at the latter's disappearance we may also find evidence of the strongly attractive force of the song (or rather the singing male) on the eager female, my own observations comprising an instance (see pp. 11 and 39-45). From this too we may decide on the value of the song in such species in bringing one sex to the other: not only does the song stop when a female joins the male, but the female is clearly re-attracted by the male's singing when she is going to leave him.

Just because in other species the song does not cease on the arrival of a female we cannot use it to prove its attractive force on eager females and therefore cannot prove its function to bring one sex to the other. Compare also Tinbergen 1939, p. 79.

It follows from the above considerations that, though direct proof is wanting, we have sufficient ground for assuming that the function of the song-flight of the lapwings like that of the song of songbirds, is to bring the female to the male territory. The principle by which this takes place is that the male by its song-flight makes himself conspicuous, whereas we may assume the eager females to be attracted by the singing male.

As in songbirds, however, the matter has another aspect: that of the territory. The song belongs to the territory and in territorial birds is hardly uttered outside its boundaries. How is this in the lapwing? We saw that the lapwing, as many territorial birds, possesses his headquarters, his stance, used more or less as a base. The song flight may start from this stance, but it may start from any other part of the territory and terminate on any part as well. In this respect the lapwing has a great freedom, but there is, I think, no bird with a true territory, which sings from its headquarters only, and the lapwing - as a rule - does not trespass the boundaries of its territory and therefore, in principle, does not differ from a willow warbler or other analogous species. Yet, there is a remarkable difference from a territorial point of view, and, as we will see further on, still more so from another viewpoint.

It was observed already that the song flight may be of very long duration and consist of an endless number of single flights. In such cases we may see the male with short intervals (breaks) cross his territory in a certain direction for hours at a time, every time after his tumble turning back on his course, to retake his previous route. The bird, as to the direction of its course, is thereby influenced through outward factors, of which the female present may be one, the direction of the wind another, and the presence of other males a third. Probably, rapid habit formation plays also an important part in causing the constancy of this route taken over the grounds.

On the evening of 1 May 1932 I studied the route followed by a male lapwing near Den Helder. The bird was unmated, but there was a female on his territory during part of the 
evening, which clearly influenced the male's course. It was also clear that the latter was influenced by the wind, and I think this was the reason why in flying in one direction the route taken differed from the route back, Now, the most striking point to be noted when such to and from flying over the territory takes place is that the tumble, accompanied by the loud final part of the song, may often, in fact in by far the most cases, be made at the territorial boundaries and not - as one might expect - on any part of the territory and only exceptionally just at its margin. Also Rinkel stresses the fact.

From a territorial point of view this is striking enough, because the song flight of the lapwing therefore not only serves the purpose to inform other lapwings about the presence of the territory, but may also tell them what are its boundaries; and though this may be of secondary importance to the birds, because on other occasions the male may not perform his tumble there at all; and also because in his fighting he possesses a very effective means to show where the territorial limits are, the fact that so often the tumble is made above the limits calls for some comment.

I think the question is thus. To be able to perform the song flight with all the violence the excited male lapwing in spring possesses a long straight stretch is needed. The flight can be flown unhampered then from beginning to end, nowhere during the zigzagging a sharp turn is necessary, the high part of the flight can be the straight continuation of the route taken before. But the territory for such an aim is small only. It is crossed by one single flight already. Therefore, if the zigzagging should proceed straight ahead, the tumble should come where the bird must turn, i.e. at the boundaries of his ground. For the only point where the bird can easily make a sharp turn is after the tumble, when it starts its flight anew. And so we see that the most obvious part of the song flight, the tumble, accompanied by the loudest part of the song, is in most cases made there where it must be of most importance in connection with the territory: along its margins. Probably we cannot say that it belongs to the outfit of the lapwings song flight to show its most striking part above the territorial boundaries; probably we can say, however, that other lapwings in many cases are well informed by the song flight already as to these boundaries.

A striking point in connection with the song flight of the lapwing and that of several, indeed most other waders is that the flight is no less elaborate a performance than the song. If it has no other function than to make the bird conspicuous this is very strange. For most species of birds it is already sufficient, when advertising themselves, that they sit high. This holds for many warblers, finches, thrushes, the great spotted woodpecker, the grey heron, cormorant etc. A number of others make leaps or short or even long excursions into the air, as we find in several gallinaceous birds, a number of warblers, pipits, larks and the like. In all these species the flight itself is simple, though in the pipits the descending takes place with outspread wings and is more or less of a performance, whereas in the greenfinch we have an entity of song and flight resembling somewhat that of the waders. Similar cases may occur here and there. But in the waders the flight has evolved to such an elaborate activity that one may ask whether making conspicuous really represents its only function. For though I do not deny that the lapwing is made still more conspicuous by zigzagging, rising to a greater height and tumbling, the whole performance looks much like an actual display, i.e. like movements performed to stress the importance of special structures or colours, in order to raise the sexual level of the other bird. We already know that the function of the song is no other than to bring the sexes to one another, or, rather, to attract a mate from afar. To come to pair formation, however, and especially to reach the stage of copulation, one or the other form of stimulation 
by display is necessary, what has led to the development of innumerable and most divergent "courtship activities" defying any trial to classify them. What, now, I mean to say is that the song flight of the lapwing takes so much the form of a display, of courtship, that one wonders whether not some display function may be contained in it, besides its song function. The same holds for the song flights of other waders: the godwit, redshank, curlew, plovers, etc. Now, there is one fact, which in my eyes leaves no doubt, that the song flight of the lapwing is used for display. In fact, I knew it was used as such long before I realized how strange this was in view of the fact that it also represents the song. On some occasions the male lapwing may perform his zigzag woo-flying in wider or narrower circles around a courted female for many seconds at a time. Observations on such behaviour are given in my diary notes for 13 and 16 May, 1926, and 29 May, 1927, continued in the second half of this paper. In these cases a new female was wooed and in my mind there was no doubt that it was because of her that the male showed this long continued zigzagging. It is true that the chief action I now (afterwards) remember from such occasions was a wild, persistent nearly absurd zigzag flying, uninterrupted for a space of time, and that, if the song and tumble were present, they must have been of less importance. This would open the possibility that it is especially the zigzag flying which is used for display, whereas it could then especially be the song with accompanying movements, which functions as song and attracts the female from afar. Apart from the fact that this would not alter the question so very much, because then, too, the song flight would serve two principles (song and display) I think this possibility may be excluded, were it alone because I feel it as of too narrow a nature.

It should be added that the fact itself that the male flies circles around the female is no strict evidence that we can call the flying display. The mere fact, however, that a certain activity is used in what may certainly be taken to represent courting, makes it highly probable that it also fulfils that function.

After all, the fact that the song flight is also used for display is not so strange as it may at first sight appear. If we look at birds like, the wood pigeon and stock dove (Columba palumbus and $C$. oenas) for instance, we soon realize that both these species have a true song, rendered by the sitting bird; and besides, a quick characteristic flight, the display function of which we have no reason to doubt. The snow bunting apparently forms another instance. It is not surprising then, that there are also birds, in which the flight contains elements of both song and display. This phenomenon seems to take a high development in the Linicolae, but at least a songbird like the greenfinch shows quite a similar principle; a butterfly like flight, which may have display function, accompanied by song. And a thorough inspection of the bird world would probably reveal a greater number of such cases.

We should not believe that with song and display value the importance of the song flight in the lapwing is exhausted. We learnt especially one activity of other lapwings may induce the male to perform his beautiful flight: the song flying of other males. This sounds natural, because there is no doubt about the function of the song flight in connection with the territorial integrity. The following scene, however, which is far from rare, prevents us from considering the song flight from too narrow a viewpoint. It is fine, sunny weather. An arbitrary male, induced to it either by internal or external influences, starts song flying. He gets now one, then the other neighbouring male on the wing. They begin flying over their territories, and more males, farther away, do the same. Soon there is one wild flying and singing over a wide stretch of polder. Gradually the males forget their boundaries and move along, first crossing the territory of their neighbours, then of birds further on. Song flying 
over long stretches they may nearly disappear from sight, one loosely behind the other or as companions at some distance, each to return after some time to his respective haunt.

Just as with the song flying when it is used to advertise the territory it is clear that no male can resist the influences radiating from the others, so that many may be taken up in the common excitement. But how can we understand that an action which primarily has the function to denote the territorial limits now does the reverse: take away all boundaries and make the whole area one field of common interest? There is no doubt that no action than the song flight succeeds better in raising the level of excitement, and, at the same time, is of so much value as an outlet for such excitement. From the fact that territorial nuisance is suppressed in such moments we must conclude that excitement is no longer sexual in the first place, but rather social, The lapwing has his social inclinations quite strongly developed; Rinkel stresses the point, and I think he is right, that the birds by preference breed in colonies. It is not strange therefore to assume that even during breeding time the lapwing has difficulty in suppressing its social inclinations. No action than this - wild flying over large stretches could better be used to contend social needs in a semi-aerial organism like the male lapwing. We find just such a wild flying - in this case of both males and females together - in colonies of terns (Sterna sandvicensis and S. hirundo), as an impressive demonstration on a large scale. Here (see also Tinbergen 1931 and 1938), social behaviour during breeding time is much more obvious than in the lapwing, territorial nuisance being restricted to minute parts of the colonial grounds. Social performances in the terns may therefore be expected to occur on a larger scale than in a lapwing, but, still, it would be somewhat strange if so little of the social instincts of the lapwing became evident during the breeding season.

This controversy is clearly what has made it difficult for Brunhilde Laven rightly to interprete the function of the song flight. She finds that the males do not confine themselves to a distinct territory, "vielmehr konnte der Balzflug eines jeden Männchen uber den gesamten Sumpf hinweggehen" . She is not acquainted with Howard's lapwing observations (see under Territory) and so is led to believe that distinct territories in the lapwing do not exist. She thus comes to the conclusion that the chief function of the song flight is stimulation, stimulation of the songflying male himself as well as of the females. "Es scheint ein gewisses Ausmass an Balz notwendig zu sein, um die sexuelle Erregung der Geschlechtspartner auf die gleiche Stufe zu bringen, damit die Kopula normal verläuft. Die Tatsache, dass jede Balzhandlung offensichtlich auf alle beiwohnenden Vögel erregungssteigernd wirkt, auf die Weibchen sowohl wie auf die Weibchen, könnte für die gelegentlich auffällige Unstetigkeit der Partnerschaften bedeutsam sein"6. In another place (p. 12), however, she seems to accept the existence of territories, but these would be of vague definition. This hesitation of Brunhilde Laven where the role of the territory and the song flight in the lapwing's life are concerned is caused by the fact that her observations were made on too restricted an area. We should do the song flight no justice to restrict its functions; in fact it is difficult to consider them from a wide enough view point.

\section{Fighting.}

${ }^{5}$ on the contrary, the flight of each male could go over the entire swamp

${ }^{6}$ A certain amount of courtship seems to be necessary to bring the sexual arousal of the sex partners to the same level, so that the copulation runs normally. The fact that each courtship act obviously has a stimulating effect on all the birds present, both on the female and on the other females, could be significant for the occasionally striking instability of the partnerships. 
An activity which plays an important part in the lapwing's spring life is aerial fighting. The pairs of lapwings hanging against a blue sky above greening meadows form one of our finest symbols of spring. They are fighting males and not birds of different sex, as the outsider would be inclined to suppose. When a male lapwing approaches the territory of another male the latter, if not on the wing already, rises, as a rule begins flying his song flight, and, if the other does not disappear at once, finishes by hanging about him to try and beat him with the wings. I quote Brock's fine description for details.

"The two birds taking part rise slowly and almost perpendicularly in the air for some considerable height, their wings beating rapidly and legs slightly dangling, one endeavouring to rise above the other. At intervals the upper bird stoops suddenly on the lower, an attack usually avoided by an agile turn of the wing; but occasionally a distinct and hollow clap is audible, indicating an exchange of blows, dealt apparently with the wing. During the course of the affair, the song is repeatedly uttered, but with the omission of the final notes. On at length parting company, both combatants break into the full song flight, repeating it twice or thrice ere re-settling in their respective stations". Rinkel too stresses the fact that the sounds uttered during aerial fighting are identical to the first part of the true song, but end before the final "weet weet", "apparently because he can only utter these syllabses if not disturbed in his flight".

Brunhilde Laven's descriptions (p. 8) state these details in a somewhat different way, so that I think it worthwhile also to quote her. "Beide Männchen fliegen etwa in gleicher Höhe hinter-, neben-oder übereinander her. Dabei folgen die Flügelschläge schneller aufeinander, als beim gewöhnlichen Flug oder beim Balzflug, und die Flügel werden nicht so weit nach unten und oben durchgezogen. Es hat den Anschein, als versuche ein Männchen das andere immer zu überfliegen. Beide rufen das kennzeichnende, zweisilbige chä chuit. Wechselnd weit kann these Verfolgung gehen. Sie können sich dabei auch so nahe kommen, dass sie mit den Flügeln aufeinander schlagen. Aber plötzlich taucht dann einer von beiden nach unten ab. Im nächsten Augenblick taucht das zweite (male) mit dem gleichen Rufen hinterher. Nahe über dem Boden fangen sich dann beide im Flug wieder auf und streben dicht über dem Boden dahin. Sie können sich dabei trennen oder auch parallel neben einander bleiben. Bald aber geht einer wieder steil hoch, der andere folgt, und der Luftkampf beginnt von neuem"7. She adds that these aerial combats may last longer than 10 minutes.

What is most interesting about this aerial fighting is that, contrary to the fighting on the ground, it only occurs in the pairing season and not during the rest of the year. Furthermore, it is restricted to the males and does not occur in the females, which only fight on the ground.

\footnotetext{
${ }^{7}$ Both males fly about the same height behind, next to or above each other. The wing beats follow each other more quickly than in the usual flight or during the flight, and the wings are not pulled so far downwards and upwards. It seems as if one male always tries to cross the other. Both call the distinctive, two-syllable chac-huit. This pursuit can go on for a longer or shorter distance. They can also come so close to each other that they hit each other with their wings. But suddenly one of the two dives down. In the next moment the second male also dives down with the same call. Near the ground, both of them are caught up again in flight and remain just above the ground. They can separate or remain flying parallel. Soon, however, one goes steep up again, the other follows, and the air battle starts again.
} 
This means that the aerial combat belongs to the sexual outfit of the male just as his song flight and song and his display.

The chief or rather the sole cause for the development of these air combats, is lying in the presence of rival males near, in or over the territory. Whereas the song flight has as its chief function to show other birds where territories are inhabited, to attract females to them, and to prevent other males from invading them, the aerial fighting represents the actual encounter especially along the territorial margins - between the owner of the territory and the invader, and the fight has as its purpose no other than to keep the ground free from the latter. It should be added that aerial fighting is never directed against female lapwings or any other birds, I think partly because such a fighting as we find in the lapwing, with two males hanging at about one height to give one another blows with the wing, is rare in the animal world.

So we come to the conclusion that to the lapwing's territory belong - just as in so many territorial birds - his song and his fighting. Of these the song, as we saw, has evolved to a specialized song flight, which combines the function of song and of display, and moreover, is used as an outlet for social feelings, whereas the fighting has evolved to a special sexual fighting (restricted to the sexually active male), of which we still have to see whether it contains more than simple fighting or not. The most common cause for fighting is the simple approach of a neighbouring male. The ordinary reaction on it from the side of the owner of a territory is that it starts flying his song flight in the direction of the other, and as often the latter does not disappear at once, they finish by hanging beside and over each other as described above. In other cases a male alights on the territory of the other before the latter was with him. A short ground combat may be the result, but as a rule it is soon continued in the air; and so all kinds of encounters of rival males may result in aerial combats, which therefore are to be seen in lapwing haunts in spring the whole day long. From a biological standpoint it is logical that those activities that are used most to attract the other sex are the first to awake the jealousy of rivals and it is therefore not strange (but I should add that I never was struck by it myself) that Brock and Brunhilde Laven (p. 11 and 13) stress the fact that nothing is more likely to bring about hostility on the part of one male than if the other should scrape or attempt to do so. This is the reason why, according to Brunhilde Laven, fighting may often follow scraping. The reader will understand what this scraping contains when reading the next chapter.

In numerous cases, however, aerial combats are not the reaction of a male on the presence of a rival, which might be or become of more or less direct danger to the territory, but apparently the reaction of a male who seeks an outlet for social needs. Besonders der Anblick (eines scheinnistenden Männchen) oder von Luftkämpfen steigert die Erregung ungeheuer. Oft sieht man ein Mänchen ein weitab balzfliegendes anderes oder zwei sich balgende Männchen geradezu aufsuchen, um sich dann lange mit ihnen herumzuschlagen"8 (Brunhilde Laven, p. 13). Brunhilde Laven, in the same way as where she is concerned with the song flight, considers this common fighting even sufficient proof that there can be no question about the defence of a distinct, narrow territory. "Zumindest ist der Raum, in dem jeder kleinste Anlass anhaltende Kämpfe auslösen kann, ganz unverhältnissmässig viel grösser als

\footnotetext{
${ }^{8}$ Especially the sight (of a scraping male) or of air battles enormously increases the excitement. Often one sees a male going after a far-away courtship flying male or two fighting males and squabble with them.
} 


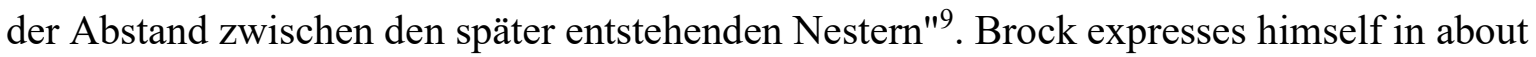
the same way "These encounters while usually individually of short duration, are incessantly occurring at all hours of the day, and have at first sight the appearance of genuine rivalry. Despite the occasional blows given and received, however, it is doubtful how far such tussles are to be regarded as real struggles for mastership or for breeding ground. There is frequently about them an aspect more suggestive of plays and the fact that they persist in unlessened frequency throughout the pairing season and long after the eggs are laid is in favour of this interpretation". The latter remark, of course, does not hold, for in many other species of birds territorial fighting is continued throughout the breeding season and long after the eggs have been laid without any one doubting its function as fighting.

It is clear that Brock and Brunhilde Laven have the same difficulty here in interpreting the function of the territorial fighting as, where Brunhilde Laven is dealing with the song flight. Because of the fact that the latter may be performed over great stretches of polder there is no reason to assume that there is no territory and that the song flight has no function in connection with the latter. Because fighting may occur when real fighting is not involved there is no reason to assume that there is no territory and no territorial fighting at all. There is not the least reason, indeed, to doubt the great and prime value of fighting for territorial defence, and, at the same time, its secondary use as an outlet for social feelings. Though Rinkel did not express himself very clearly I think he is saying the same. Whereas he mentions fighting in connection with territorial boundaries he states that the birds go on fighting, often at the least inducement, after the territorial limits are long definite (this reasoning contains the same mistake as that of Brock). "It makes the impression that the birds need this "play" and we should not be astonished nearly always finding a number of territories lying closely together. Lapwings rarely breed alone, I saw this only once". And so in my mind it is: the male lapwing, as a social bird, uses not only his song flight, but his territorial fighting as well, to contend his social needs, a group of neighbouring males, though defending their respective territories, wholly behaving as the individuals of a colony.

Again as where we were concerned with the song flight, it is relevant to ask: but how is it possible that an action, which serves in the first place to keep neighbouring males away, may also serve the purpose to contend social needs. I think, this step is not greater after all than where the song flight is concerned. The answer lies not in the contradictory aspects of the fighting, but in the changes in the birds themselves. The male has, to use Howard's words a disposition to defend the territory, but, besides, a strongly developed social instinct. These two are in equilibrium, but now at the expense of the one, then of the other. The very moment the social instinct wins there is no longer the true disposition to fight, only an activity resembling it. Perhaps we may say: true fighting is physical fighting and mental fighting combined, social fighting is physical fighting and mental play; but I have a certain dislike for phrases. The chief point is that activities of quite different directions can be used as an outlet for social feelings. I am too little trained psychologically to know whether this is of any importance from a more general viewpoint.

Our answer, then, to the question what the aerial fighting of the male lapwing contains, is: it represents fighting to defend the territorial integrity but at the same time is used as an outlet for social feelings. There is, I think, little reason to assume that, besides, like the song flight,

\footnotetext{
${ }^{9}$ At least the space in which every slightest occasion can cause lasting fighting is quite disproportionately much greater than the distance between the later nests.
} 
fighting has some display function. Of course, any activity of one sex will have its influence on the other (for interest of the females in the male's fighting and other doings see the second half of this paper,), but that is a different question. My observations never gave me the impression however, that fighting meant some form of display.

Aerial combats are to be seen constantly, but this does not contain that the male during the mating season should not be able to fight his rivals on the ground too. In many cases a foreign male may invade a territory in the absence or during a short in attentiveness of its owner. On such and other occasions it often happens that the invader refuses to take to the wing on the approach of the first, and the owner starts swooping down on the invader then to drive him away. The stranger now tries to evade these blows by rapidly lowering its head (which is kept directed towards the stooping bird all the while) so that its tail points nearly perpendicularly into the air for a moment. At the same time it twirls round like lightning to face the aggressor anew, the head high now and the tail low. As the stooping bird is growing more and more wild, the threatened bird, which may be pressed to crouch, its head and twirl around many times in rapid succession, will rarely stand the assault. It finally takes to the wing and the fight may be continued in the air or the stranger may disappear at once. Brock, Rinkel and Brunhilde Lavel described these combats already. Brock says that the threatened bird may evade the blow by swerving aside or by little upward springs into the air. But in my mind the rapid lowering and twirl are the rule. He also states that such struggles are at times most obstinately persisted in by the two birds - sometimes for as long a period as an hour or an hour and a half on end. Combats of such fierceness are a great exception, however. Rinkel illogically compares the attitude of the threatened bird to that of the skipping or rather to what he calls the imposing bird, see below. He even goes so far as to state (p. 116) that skipping may express imposing, defence or alluring. But it would be wrong to call the once moving up and down of the tail at each stoop skipping. The two actions agree only quite superficially. Brunhilde Laven, who mentions this kind of fighting shortly, calls it "Anfliegen".

Combats as described above may not only last for a very long time, but they may also be quite furious, the more so the longer the struggle lasts. In some cases the invader obstinately refuses to leave the ground and in such cases the result can be twofold. Either the owner of the territory, becoming more and more desperate, gives the struggle up. In this case we just see how impotent a male lapwing is when his enemy refuses to take to the wing. Or the owner of the territory finally alights near the other and now begins fighting with two wings out, running in at the other -and beating him violently. The state of furious anger to which such combats raise their participants can hardly be described. These quite fierce combats are rare, however. Brunhilde Laven, who shortly describes them and calls them "Hahnenkampf", supposes that the numerousness of Hahnenkampf (fighting of two birds on the ground), Anfliegen (one bird on the ground and one in the air) and Luftkampf (two birds in the air) may be related as about $1: 40: 200$. Brock remarks already that ground combats especially occur in the early part of the season, when they may be fierce in the absence of any female. Later, when the territories have been staked out and possibly the males have also grown more or less accustomed to each other the birds do not so often come to farther than to aerial combats, which, however, also during early spring, are far more numerous than ground struggles.

The fighting described up till now has several times above been denoted as territorial fighting. The reason is that, as in territorial birds in general, it is bound to the territory and except in cases of what we could call social fighting which is more communal in nature - 
practically does not occur outside the latter. The female in territorial birds is defended by way of the territory so to speak; the male, in defending the territory at the same time defends the female, be she present or not. Though the territory in the fighting of territorial males comes more to the fore than the female, cases like the one just mentioned show that the role of the female should not be neglected. The male possesses the same jealousy towards rival males as the female towards rival females. For this reason Tinbergen (1939) prefers to call this fighting, which clearly occurs as fighting "for the female" everywhere else in the animal kingdom, sexual fighting. But just its combined purpose generally: to keep rivals away from the female as well as from the territory, makes me prefer the other name. What name we give is little important however.

The male fights on his territory and little outside it, except along the margins or when fighting "socially". There are occasions, however, on which a male may fiercely fight well inside the territory of another, though he has a territory himself. I possess few good instances of such cases, one of the best of which refers to an observation in the evening of the 29th May, 1927, when three males invaded the territory of a fourth, there to court a female which was courted by the owner of the territory too (see diary notes), As a result furious ground battles developed, continuously accompanied by heavy wing strokes. It was the heaviest lapwing fight I have ever seen. In this case three of the males were fighting outside their territory clearly because they wanted to court the female in question, and in all other similar cases there is no doubt that fighting was directly for the female.

How is it with all this fighting in the female? It was already observed that aerial fighting is absent in her and that all fighting takes place on the ground. But fights between females inter se are many times rarer than fights between two males. Females only fight in case there is a direct cause: another female in the neighbourhood of the male. In the introduction to this paper I referred to the fact already that polygamy is of rather common occurrence in the lapwing, one male often courting and mating with more than one female. It will follow from the second part of this paper that in all these cases heavy fights between females may be the result. These fights are suppressed by the males as much as possible (see second part), but this cannot hinder the females to continue the fight again and again. Whereas the male tries to keep another male away from his territory (including a female or not) the female clearly has one aim only: to keep the rival female away from the male.

When dealing with the males we learnt that, according to Brock and Brunhilde Laven, they are much stimulated to fighting by the sight of scraping rivals. It is therefore of interest that in just the same way rival females are especially brought to fight by seeing each other scrape, a fact also remarked by Brock. Though females rarely scrape they may be stimulated to scraping by the presence of a rival, probably because then they are most stimulated sexually, so that their display, which normally is inhibited, is brought to the fore. The scraping stimulates their fighting, and so two such females may raise each other's fighting to furious battles.

It should here be added that males fight only males; females only females and that never have I seen either fights of pair against pair or of one bird against a bird of the other sex. This is of interest in connection with Tinbergen's similar remarks on the snow bunting (1939, p. 26-28).

Very light ground combats, no more than skirmishes, often resulting from food rivalry, but I think as often from remains of territorial instincts, may be constantly seen from lapwings 
outside the breeding season. This fighting is no more than running in of one bird, its neck stretched forward, horizontally at the other. On reaching the latter, the aggressing bird at once stops, lifts the head - the crest erected - and towers opposite the other. This now for a moment partially spreads its wings and runs away, or runs away with both wings out, or flees a shorter or longer stretch on the wing. Both birds may make a "teering" sound, consisting of a rapidly repeated, somewhat hoarse (husky) "tee-tee-tee-tee", of shorter or longer duration, often preceded or followed by "kee-ee-weet". This sound, especially the "tee-tee-tee-tee", one hears much at night from feeding lapwings; it is doubtless without exception accompanied by chasing then. The sound seems to be omitted in skirmishes between males in the breeding season; I do not remember it from that period at least. It may be made, however, when a female bird in the breeding season is chased by a male, compare my diary notes under May the 29th, 1927. I do not know what role the sexes play in these fights outside the breeding season.

It should finally be added that fighting males look distinctly angry and that their outward appearance agrees with that of males alighting near their wife and going to chase her or to show the stiff attitude (see further on). In other words, I have no doubt that such males, who are going to stiffen (see below), are angry with their wife. Moreover, I used this outward appearance of the males, in case they were polygamous, to conclude on their anger again and again when their wives were mutually fighting and the male interfered. As will follow from the facts discussed in the second part this was often valuable.

\section{Courtship.}

The male lapwing in spring began by isolating himself on a restricted area, which was defended against male intruders by fighting and by flying his song flight, so that females might be attracted to his territory. The next step should be to win the female-visitor so that she remains with him.

A somewhat nervous lapwing, for instance a bird watching a man, while engaged with its ordinary walking with short runs, may be seen to peck at the ground again and again, apparently without taking up food every time. I think this is a very simple form of outlet for excitement. It is borrowed so to speak from true feeding activities. Tinbergen $(1939$, p. $225-$ 228), who gives a number of instances of pecking movements under similar circumstances in other birds, calls these movements substitute feeding, "because they replace fighting activities induced by the situation". He is of opinion that such substitute activities find their main cause in the fact that a normal reaction is blocked in some way, e.g. under the influence of two antagonistic drives (in boundary quarrels) or when a normal reaction chain breaks off (in courtship activities). At the same time he is convinced, however, that a certain substitute activity is fixed, characteristic of the whole species and therefore inborn. This means that we would have to consider it a reaction on outward circumstances just as the other activities preceding the substitute action, in other words, the substitute activities would belong to the normal arsenal of reactions, to quite the normal outfit of the species. If that be true (and I think it is) we could only suppose that there activities have arisen as substitutes phylogenetically, but in that case I should prefer to call them "borrowed", borrowed from other parts of the birds activities. 
Now, a male lapwing which is going to perform the action to be described in this chapter as a rule can be seen to make just such a pecking movement, but now not by lowering his head, but simply by bringing it fore- and again backward by short jerks, so that he seems to peck at the air just in front of him for several times in succession. This pecking at the air can probably best be considered the introduction to what I shall now describe as "nesting", though I do not know how often nesting does not follow pecking and how often pecking does not precede nesting, as I did not realize the correlation between both movements before I had nearly finished studying the birds.

The nesting ceremony itself can more or less naturally be divided into three parts, which I shall call skipping, scraping and stick throwing. Especially the third part, though forming part of the whole on all occasions the ceremony is performed, is at the same time often used independently. When both other parts are shown independently, however, it is rather because of a break in their continuity than due to their representing independent activities. Especially after the first activity, skipping, this break is shown quite often.

\section{a. Skipping and scraping.}

The first part of the "nesting", called by me skipping, in its most complete form consists of the following. The male, while on the grounds with hindbody and tail directed obliquely upward, begins moving (skipping) his body, wings and tail up and down, whereas the head and neck remain motionless or almost so. This is only possible, I think because the body pivots on the heel joints. Brunhilde Laven says that alternately head and hind body move up and down, and this is what one is inclined to write down, because the movement otherwise is so difficult to understand, but in reality the head in comparison with the hindbody, wings and tail is kept still. She also says that every time the bird skips the tip of the wings move somewhat from each other, a movement I well may have overlooked. According to her the tail remains narrowly closed all the time. This first part of the skipping, like the pecking preceding it, is performed at the least inducement and is the very first outlet for growing (sexual) excitement on the part of the male on numerous occasions. It quite easily breaks off, to be repeated again and again on next occasions. Brunhilde Laven says the movement may last at its most half a minute, Selous (1902) describes how the male at intervals "turns on his feet, where he stands, round, or nearly round", and, I think, this statement is quite right. The performance enters its second phase so to speak when the bird sinks or falls down with its breast on the ground, so that hind body, wings and tail point obliquely upward. The crest points perpendicularly into the air. At the same time skipping continues, so that especially hind body and tail move up and down. The wings are pressed tightly against the body, making an up and down movement in such a way that the ends of the wings and the tail move up and down together. The wings thereby make a rubbing movement by moving in the wrist.

The performance of skipping with the breast pressed on the ground (as well as that of scraping which is described below) may be accompanied by a strange sound, something like the sound made by a saw. Brock describes it as "a strange grating sound, usually harsh in tone, but varying at times to a more plaintive pitch". It is a true vocal sound, which, I believe, is often produced with the bill closed, but the bird may also have its bill half opened, in which case it looks agitated. It is a strange fact that on some days a certain bird when skipping may "saw" very much, e.g. a whole evening, whereas on the next evening it does not "saw" at all. Brunhilde Laven, who describes this sound for the scraping, not for the skipping bird, says she does not know whether during scraping it is made always, "da es schon bei leichtem 
Wind unhörbar wird oder in anderen Geräuschen übergeht" ${ }^{\text {"I }}$ I have difficulty in believing this can be the reason why I heard it much on some occasions and little on others, I should think there were very quiet evenings when the sound was well audible and nevertheless to be heard now and then only. On rare occasions the sound was made during other actions, in which normally it was altogether absent. Such occasions were very great exceptions; however, I remember only two cases. One of these was when the sound was produced by a male flying up to a female to copulate with her, once I heard it made by a zigzag-flying male. To me it seemed possible that the sound is made by the male under the influence of strong sexual desire. Its biological significance could lie in the fact that it may be a better means to allure a female (see below) than by movement alone.

The case in which a zigzag flying male uttered the sawing sound is described here. On April 27, 1932, a male which I was observing for some time near Den Helder, was flying courtship in an endless way. During the zigzag part of the flight he uttered a modification of the sound, sounding like "ee-ee-ee-ee", etc. or "e-e-e-e" (french pronunciation), but the ee's were produced with such short intervals that it resembled one continuous sound instead of a sawing one. This male was under the influence of great sexual desire, for it furnished me the only instance of a male lapwing trying to attract another bird (viz. a redshank) by his scraping, see further on. The sound may therefore well express great sexual desire.

After a spell of skipping the second part of the performance, the scraping, is given. Two fine photographs of it are given by Rinkel, whose drawings of this and other actions are also quite instructive. The breast is at once pressed violently into the ground. The wings, which stand off from the body now, point nearly straight upward, projecting like two horns on each side, as Selous says. Brunhilde Laven observes that their wrists may rest on the ground, and this must certainly be the rule. The hindbody points obliquely upward, and the tail which is directed horizontally or somewhat upward, is depressed in a rapid series of successions, a fact noted by Selous, Brock and Brunhilde Laven. The head is stretched a little forward. Meanwhile the sawing sound may be produced all the time, whereas the beak may be a little open again. This whole performance is of very short duration. Selous stresses the resemblance to copulatory movements because of the convulsive, spasmodical moving up and down of the tail, but this comparison to me seems unnatural. The whole performance, when looked at from close quarters, is still more remarkable because of the rather rapid trampling of the legs below the tail in a backward direction. According to Brunhilde Laven the legs thereby stand farther apart than is normally the case and they are bent strongly in the heel, so that they support the hindbody. "In dieser Haltung beginnt der Vogel mit den Füssen kräftig, aber nicht sehr hastig, von vorne nach hinten über den Boden zu scharren. Während des Scharrens klappt der Schwanz auf und ab, sodass man für kurze Augenblicke die scharrenden Füsse sehen kann, im nächsten Augenblick aber sind die Beine wieder vom Schwanz verdeckt. Der Schwanz wird jedes Mal beim Herunterklappen stark gefächert und auf den Boden gedrückt, beim Hochklappen wird er wieder etwas zusammengezogen. Die Beinbewegungen und das Schwanzklappen verlaufen nicht im gleichen Rhythmus. Sekundenlang, während die Füsse weiterscharren, kann der schwanz auf den Boden gedrückt

${ }^{10}$ Because it becomes inaudible even in a light wind or lost in other noises. 
bleiben"11. This means that Brock's remark that the tail movement corresponds with energetic footwork should not be taken too literally.

I myself could not with certainty make out whether the feet actually scratch the ground or merely trample on it, but already Brock says the bird does scrape energetically and Brunhilde Laven says that on sandy soil one can distinctly see the sand flying backward, and the same holds for some of lapwings relatives. Selous in his descriptions calls attention to a side to side movement of the scraping bird several times, a movement I myself may have overlooked. It probably results from scraping now with one leg, then with the other. I think it may be because of this movement that Selous denotes the action of skipping and scraping by "rolling". I am sure however, Selous overestimates the side to side movement of the bird, and it seems not impossible to me that there is hardly such a movement at all, and that Selous has taken the up and down movement of body, wings and tail for a side to side movement.

The scraping animal looks most remarkable when viewed from behind. The auburn upper and the beautiful pink-cinnamon undertail coverts, together with the white feathers of the sides of the rump and vent, which all stand out, are to be seen to their very best advantage and, combined with the white and black tail and the red backside of the trampling legs. Moreover, the light spots on the outer primary feathers, which, as already stated, point straight upwards are very distinctive. What, now, is the result of this remarkable ceremony? We can be short, for its action on the female is, on the whole, striking: it attracts her. The male not often shows the second phase of skipping when a female is absent. He even prefers displaying more or less in her immediate neighbourhood again walking up to her before going on in case she leaves him. He invariably sits down in such a way that the tailend of the body points in the direction of the females a point also stressed by Selous, Brock, Rinkel and Brunhilde Laven. When the female observes the male skipping it rarely happens that she does not react at all; most of the time she becomes at least attentive, though she may go on feeding. When, however, the male begins scraping, she as a rule becomes quite attentive and in most cases begins walking in the direction of the male.

The male may continue his display, skipping alternated with scraping, for several and even many minutes at a time. On occasions when he is very excited, and when the female does not come up to him or approaches only very slowly, his skipping and scraping takes no end, compare, e.g. the diary notes for 30 April, 1926, when another male allures female A.

The final result, then, is in many, in fact most cases, that the female comes up to the male. She approaches him closely and now he steps out of his depression whereas she sits down in it, presses her breast downward and performs the ceremony herself now. As a rule, however, she omits the skipping and commences scraping at once.

In the meantime the male begins a new phase of the whole ceremony, the third part of it mentioned above: stick throwing. He starts nest-building, but in a very strange way. He takes

${ }^{11}$ In this position, the bird starts to move his feet strongly, but not very hurriedly, forward and backward on the ground. During the scraping, the tail is moved up and down so that one can see the scraping feet for a brief moment, but the legs are hidden by the tail again. The tail is strongly unfurled and pushed down to the ground every time. When folded back, it is again somewhat contracted. The leg movements and the tail flap do not run in the same rhythm. The tail can remain pressed down on the ground for seconds while the feet continue scraping. 
up stubble's, roots, straws or grasses from the ground and throws them over his back behind him, his head moving sideward with a sudden jerk at each throw, now to the left, then to the right. In doing so he walks away from the female, so that the first grasses fall in her neighbourhoods whereas the other ones come down at some distance from her.

After some moments the female leaves the scrape and begins throwing grasses in the same way whereas the male runs back to his original place and goes on skipping and scraping again. When the birds are both very excited (that is to say, when we may conclude from their persistence in scraping on excitement) male and female may change their roles a few times in succession until they both go on feeding again. Generally (perhaps always) it is the female which makes an end to the mutual display.

Selous stresses the resemblance between the scraping and the copulating bird and is apparently led to assume that the scraping represents a display borrowed from the act of coition. This is certainly not the case. First of all, the resemblance between scraping and copulating is quite superficial only, or rather, on closer inspection does not exist at all. Secondly, it follows from the description of Van Beusekom (1930, p. 52 -55), that there is striking agreement between the activities of skipping and scraping on one hand and the way in which the bird which is going to brood its eggs settles down on the nest on the other hand. In the oystercatcher true scraping according to Van Beusekom even takes place every time the bird settles down on the eggs, when it is bringing its long legs forward below its body. There is, therefore, in my mind little doubt that the skipping and scraping contains a symbolized settling on the eggs for incubation. We will see further on that the stick-throwing doubtless is a symbolized nest-building. The whole of the display therefore has been borrowed from the nest-building and brooding activities. As stated above there can be little doubt as to the biological function of the skipping and scraping ceremonies. First of all, the action makes most deliberately use of the showing of the most strikingly coloured parts of the bird: it represents a very true display movement. Secondly, it is preferentially shown in the neighbourhood of the female, whereby those parts, which are most strikingly coloured, are turned towards the latter. Thirdly, the female as a rule may be seen very distinctly to react on the males display, which can be said directly to attract her. The result of the scraping therefore is that the female is brought in close neighbourhood of the male. Thereupon, he starts stick throwing and she sits down. I do not know what part of these activities is based on stimulation by either bird but one thing is certain: that the birds, which have been brought together by the scraping, finish by showing something like a mutual display. This display, as will follow below showing something like a mutual display, is not the introduction to copulations. It apparently serves no other purpose than to keep the birds together for the time being. The function of the ceremony then clearly is that the female is brought into close neighbourhood of the male and kept with him. We find a complete parallel here to the courtship state of affairs in activities of the great crested grebe, studied by Huxley (1914). We have the same course of events here as in so many other birds: the male stakes out a territory which is maintained by keeping off other males, and in which he makes himself conspicuous by his song-flight, the female is attracted to the male territory, and then, through his display, into the neighbourhood of her mate. It should be added that the mating may be said to be completed through the mutual display.

Descriptions of skipping and scraping have been given by Selous, Brock, Miss Haviland, Rinkel and Brunhilde Laven. Partial descriptions are, moreover, to be found in several more or less popular works. These are especially concerned with stick throwing, however, and 
therefore mentioned further on. Selous' diary notes (1902, also 1905) contain short descriptions, to which! have alluded where necessary. I stated already that Selous speaks of the skipping and scraping as the rolling bird. His remark in his paper of 1905, "that, in the greater number of cases the performing bird is paid no attention to, and does not, itself, appear to wish to be, being often, to all intents and purposes, alone", is far from the truth and in contradiction to his own descriptions. A male in the beginning of spring may often be seen to perform his nesting ceremony alone in the absence of any female. But this does not contain that, because the female may be absent, the male does not try to allure her, neither that the female shows no interest in the males scraping.

Brock's description of the Lapwing's nesting is very clear and his descriptions are easily to refer to mine. Just as I have done above, he also describes how the male after the female has left the scrape, returns to it to resume his scraping, thus sometime alluring the female a second time. "Such a scene as this, of male and female working in turn in the same scrape may take place with the same pair of birds at not infrequent intervals during a single day, and it is nearly always terminated for the time being by retiral or loss of interest of the female" ( $p$. 302).

There is one point, in which my description differs from that of Brock. Brock says that when the female approaches the nesting male the latter rises from the scrape and takes a step forwards "adopting as he does so a curious and striking pose". "Keeping his back turned towards the hen, now very close beside him, he slowly lowers his bill to the ground and raises, his tail almost perpendicularly in the air, his richly coloured under tailcoverts thus, prominently displayed. The female now sits in the depression and scrapes. During this interval the male retains his remarkable uptilted attitude, standing a yard or so in front of his mate, employing himself in the collection of nest material, which is jerked backward over the shoulder in the direction of the scrape.' I wonder that this striking pose has never succeeded in calling my attention, though I saw birds change nesting perhaps some hundreds of times. Brunhilde Laven, too, whose description is very complete, makes not the least mention of it. Personally I am therefore inclined to believe that Brock wrongly interpretes the simple standing near the scrape and the walking away of the stickthrowing male as a special courtship attitude notwithstanding the fact that Rinkel, who gives also a drawing of the mutual ceremony, apparently quite agrees with Brock. I must admit, however, that I have never even been struck by the particularity that the male, also in walking away from the scrape constantly keeps his tailend directed towards the female, so that it seems possible that Brock is at least partly right and I myself am partly wrong.

Miss Haviland distinguishes the courtship actions sensu lato as the aerial tumbling, stone picking, hustling 1 and 2, and the display. Her descriptions are quite poor and her interpretation of their meaning is partly false. The aerial tumbling according to her has nothing to do with the courtship proper, though the latter is defined as "all behaviour that is peculiar to the bird in the spring time'. Stone picking is our stick throwing, and in the female "it is not indicative of more than a certain amount of restlessness and physical discomfort". Hustling 1 and 2 is skipping and scraping, described partially only. Finally, the display is the female's taking the place of the nesting male, but apparently joined to the stiff run of the latter, see below. Miss Haviland supposes that "the only part of the performance which is a deliberate display to a prospective mate is the exhibition of the anal part". This and her description itself show that she was well aware of the fact that the male turns his back to the female while "nesting'. Referring to Howard Saunders' "Manual of British Birds", in which 
it is stated that "the false nests are scraped out by the cock in turning round when showing off to the female", she believes that the action has little to do with charming the latter, as she often is absent. She further doubts Selous' observations, according to which the female would "roll" too, comments which Selous himself has answered in a later paper (1916).

Rinkel believes he can distinguish two skipping actions, one of which is used as imposing attitude, the other as an invitation to "nest building. They would differ from one another, because during the latter the male turns his back to the female, during the former not. The skipping as an invitation to nestbuilding would be always followed by scraping, the skipping as imposing attitude not. In my mind there is no doubt that the actions cannot be separated. Skipping is used as a quite general form of outlet for excitement. It may develop into a skipping with the breast pressed on the ground or it may remain superficial. When remaining superficial efforts to allure a female are still absent and there is no necessity of turning ones back to the female. I do not think that this superficial skipping has anything to do with imposing and Rinkel gives no reasons for his belief. The whole matter is made still more confused by Brunhilde Lavens considering this skipping a kind of "Bodenbalz", comparable to the possible instances she cites of such a display. In these latter cases there is no question of skipping, however, only of a male making himself high and broad and, in a few cases, turning his back to the female; but this showing its back is just what would be wanting in what Rinkel calls imposing.

Brunhilde Lavens descriptions of skipping and scraping, finally, have been referred to several times already; they are excellent, in fact several details have been better seen by her than by me. She too describes how the male during nesting "bestrebt ist, dem Weibchen das Hinterteil mit dem auf- und abklappenden Schwanz zuzukehren"12.

Before going on I should still add that I did only a few times see a female scrape of her own accords, see e.g. my diary notes for 13 and 14 April, 1926, and 3 April, 1927. This scraping was performed when apparently her jealousy by the presence if a rival had been raised to a very high level. It had a bad effect on the rival female in so far as she became furious every time her enemy scraped. It is remarkable, then, that jealousy towards a rival does succeed in making the female scrape of her own accord, whereas she performs it quite exceptionally of her own even when a male is present in her neighbourhood. On June, the 4th, 1925, a feeble "nesting" consisting of skipping and scraping, was seen from a female, which was probably alone. I may have observed this on some few other occasions but certainly very exceptionally only. Brock, too, describes such jealous females. "On such occasions the two rival birds, settled near each other, sway their tails up and down rhythmically and scrape slightly, plucking a little at straws. Ultimately one may rush at the other, and a short bout of brisk sparring ensues." Brunhilde Laven's statement, therefore, that the female, after having taken part in the mutual nesting in the earlier part of the breeding season, lateron may be seen nesting of its own accord, is not quite right. In reality she should have used the term "Schleudern" (throwing or replacing of sticks) here instead of the word "Scheinnisten" (my "nesting"), as it is the throwing with nesting material only which is actually studied more and more by her and not that part of the "nesting" called by me scraping. Skipping and thereupon scraping may take place when exterior influences do not visibly interfere, but also when the bird is apparently clearly stimulated through such influences. Feeding birds, apparently without being influenced at all by companions, may at once begin skipping, and though as a

12 tries to turn his bottom to the female, with his tail raising and lowering. 
rule they may not reach the stage of scraping, may scrape in the absence of any other lapwing. I already cited Selous to the same extent, and Brock and Miss Haviland remark the same. Rinkel (p. 129) too states that many scrapes are made spontaneously, that is to say not under the influence of the female's presence. Also Brunhilde Laven (p. 23) says: "In dem nicht seltenen Falle, dass ganz isoliert stehende Männchen Sheinnisten anfangen, kann man neben der Disposition des Tieres hochstens den Anblick einer geeigneten Stelle als Auslöser dieser Handlungen annehmen"13.

On the whole, however, as already pointed out, the presence of a female greatly stimulates the male and makes him skip and scrape more energetically and more persistently, a fact already stressed by Brock. On the whole, skipping is especially begun after some kind of stimulation, though in many cases it is difficult to make out to what degree the stimulus is the preceding behaviour of the male itself, the presence of the female, or the presence of other males. The behaviour of the male may include such actions as song flying, fighting, feeding, etc.

In all cases where the males own action was apparently of simulative influence probably the rule is that the skipping and consequent scraping follow the emotion of the song flight. They may follow this either directly or indirectly.

When directly, the male, after having performed his song-flight may alight at some distance from the female, run to one of the depressions formed by scraping a former time, and there begin skipping. This rapid run over a long distance is very distinctive and may have given rise to the Dutch expression "to run like a lapwing". In such instances it may be the combined stimulation caused by the song-flight and the presence of the female, which leads to skipping.

When skipping and scraping follow the song-flight indirectly either the act of copulation or what I shall call the stiff attitude are as a rule inserted between the end of song-flying and skipping. These actions are only described further on, but for the sake of clearness are mentioned in this connection here. Though song-flying is no necessary preliminary to copulation the latter may often follow it. In such cases the male, after having copulated, often runs away to one of his scrapes and starts skipping and thereupon scraping. Thus, in such cases copulation is just inserted between the songflying and the running away to the scrape, without further action taking place between. Already Selous (1902) stresses this point.

Now and then we see a male fly right down to a female as if copulation will follow. Instead of that, however, we see him alight beside her, and a very strange attitudes which I have named the stiff attitude, generally follows. Mostly the stiff attitude is followed, just as the copulatory act, by the run to one of the scrapes and skipping and scraping.

In all these cases skipping and scraping, either directly, or after copulation or the stiff attitude have been inserted, follow the emotion of the song flight and it is difficult to say in how far the presence of the female contributes to raising the males level necessary to start skipping. It is logical to suppose, however, that the presence of the female greatly stimulates the activity of the bird also here, as there is no doubt that the chief function of "nesting" is to attract the female.

${ }^{13}$ In the not infrequent case that very isolated males start scraping, one can, in addition to the disposition of the animal, take the view of a suitable place as the initiator of these actions. 
On rare occasions the male may be stimulated by an inadequate object, or at least may be influenced by it. But this is certainly very rare, the only instance I know it was a redshank, to which a scraping male turned its back as though it was a female lapwing. The observation is cited below.

When dealing with the sawing sound. I referred to a male without female, observed near Den Helder on 27 April, 1932, which made the sound during the woo-woo-woo-part of the songflight. I stated already that this male continued his song flying for a very long time." It is quite excited. After having alighted on the meadow for a moment it again starts flying immediately. Now and then the bird skips somewhat, some few times it comes to scraping. This was in close proximity of a redshank and when it began its display its head was directed towards the latter, but when scraping was taking place its hindbody was directed towards the bird. This scraping was continued for a long time and quite violent, so that I am convinced it was destined for the redshank. When, at about 19.15 the sun settled, the bird became more quiet and, having alighted, remained longer at the spot, now continuously calling "Kee-eet". This still was going on when I left at 20 o'clock."

This observation represents a fine instance of lowering of the threshold value for scraping with a female, due to great sexual desire in the male because of the absence of a female lapwing. Though I can give no arguments in favour of this belief, I think the call "Kee-eet" too was used here as an expression of great sexual desire. Anyhow, it expressed great, apparently inner excitement. In the evening of May 7 and the morning and evening of May 8 , 1932, the same or another male without wife was making this same call continuously. Instances of males, who do not succeed in winning a female, are certainly very rare and I suppose that to this fact the rarety of the use of this sound must be attributed. - I should add that the male of 27 April a few times flew round somewhat rolling before coming down on the meadow and, again, this made the impression on me to represent an extra movement due to great sexual desire. The movement called to my mind an analogous movement observed in a male heron showing great desire (compare Verwey, 1930, p. 68 - 69), and quite a similar behaviour was once seen in a female lapwing, see my diary notes for May $11^{\text {th }}, 1926$. It follows from the foregoing details that there is a certain regularity in the course of events, so that a series of actions may be said to exist.

The song-flight may be followed by copulation, this by the run to a scrape, skipping, scraping, this again may lead to joint nesting and stick throwing. Or the song-flight may be followed by the angry and stiff attitude (see furtheron) and this in just the same way by the run to the nest, skipping, scraping and the joint nesting and stick throwing. Thirdly, the songflight may at once be followed by the run, skipping scraping etc.

This does not mean that copulation may not follow other actions than song-flying, and that the run to start skipping may not follow other actions than the song-flight or copulation, but it does mean that a certain regularity in the course of events cannot be denied to exist, though the latter is specially evident in the second half of the series, where skipping, scraping, nesting together and stick throwing are concerned.

Rinkel, who also draws attention to this regularity, and gives a similar scheme of actions, as the one given above, is criticized by Brunhilde Laven to the effect that his scheme represents at its most an "Idealfall"; "die Wirklichkeit sieht viel weniger starr, viel wechselvoller aus. 
Viel häufiger bricht die Kette an irgend einer Stelle ab, sei es durch Störungen von aussen her, sei es weil die Erregung des Handelnden vorzeitig abebbt oder die Zusammenhandelnden nicht gleichgestimmt sind. Keineswegs kann ich z.B. zugeben, dass nach einer verweigerten Kopula stets die Scheinnistkette von neuem beginne; ich sah dasselbe noch nicht einmal in jedem zehnten Fall. Viel häufiger geht das Scheinnisten des Männchen aus einfacher Nahrungssuche hervor, oft genug in Abwesenheit eines Weibchen"14. What she says is true, but she overlooks the fact that Rinkel himself at once has made these same restrictions, adding that the scheme is not followed rigidly ("star"), and that all kinds of circumstances may be the cause of a break. I think the apparent difference of opinion between both views in reality does not exist, but Rinkel, less trained in ethopsychological direction, is glad to find rules and mentions variation in behaviour as side issue, whereas Brunhilde Laven approaches the subject just from this side, somewhat neglects or has some difficulty in figuring the mean course of events, and gives variation in behaviour its full share. Rinkel's series of actions begins, however, contrary to mine, with the flight of the male to the females which leads either to copulation or the stiff attitude. Rinkel - as will appear below - attaches much value to this flying up of the male to copulate with the female (too much in my mind), and considers it of stimulative value and most important in connection even with pair formation. I find, however, that the sexes are much stimulated through the male's song-flying, that this may lead to copulation and this again, just as the song-flight itself, or fighting, or feeding, may lead to mutual nesting, because nesting may result from any action which raises the level of excitement.

Though I do not want to "explain" the existence of such a series of actions from the degree of stimulative power of each action I think it worth while to speculate somewhat on the matter. The presence of either a male or a female in the neighbourhood of a male may easily lead to song-flying. There is no doubt the song-flight has great stimulative power on both sexes and as a result the threshold necessary for copulation may be reached by one sex or both. If by one only, the end result does not make much difference. One may also replace the word songflight for fighting or eventual other actions. Less excitement than for copulation is wanted to start skipping. It may therefore easily follow after copulation, but after many other actions as well. Skipping stimulates the performing bird itself to the next action: scraping and both actions have an increasing effect in alluring the female. Her approach leads to mutual display, i.e. joint scraping and stick throwing. As the series always breaks down after stick throwing, which never leads to copulation, and certainly not often to renewed skipping, we must assume that nesting and stick throwing use up all excitement so to speak. Huxley (1914, p. 509-511) names such actions self-exhausting.

This would mean that in the lapwing everything is made subordinate to pair formation. The same activity (display), which in the grey heron leads to copulation, in the lapwing is used to bring the birds in close neighbourhood of each other but not to copulation. The birds may, therefore, be said to mate as soon as they scrape together; though copulating will soon follow this joint scraping mating - just as in many other territorial species - takes place

\footnotetext{
${ }^{14}$ Reality looks much less rigid, much more varied. Much more frequently, the chain breaks down at any point, whether through disturbances from outside, or because the excitement of the agent prematurely subsides, or the co-workers are not in the same mood. I cannot, for example, admit that, after a denied copulation, the nesting chain would always begin anew; I did not even see it in every tenth case. Much more often the nesting-chain changes in a simple food search, reasonably often in the absence of a female.
} 
independently of previous copulations. Selous (1905), probably because in his eyes scraping resembles the act of coition, supposes that rolling (i.e. scraping) may, more or less, take the place of copulation. When copulation is followed by "rolling" he suggests $(1902, p$. 141) that the primary sexual instinct (copulation) contains, and gives birth to, the secondary nest-making one (scraping). This belief has connection with his belief that nestbuilding gradually developed from frenzied sexual antics, a train of thought which I do not think makes sense.

Till so far the question of stimulation and what is annex with it. Brock states that the males show greater jealousy of each other when scraping than on any other occasion, and when two birds chance to be standing quietly near each other, nothing is more likely to bring about hostility on the part of one bird than if the other should scrape or attempt to do so," I, personally, was never struck by this, but I do not doubt the correctness of Brocks observations, the more so, because also Brunhilde Laven says that especially the presence of a nesting male may easily lead to fighting. The statement is of interest, because exactly the same as was stated under fighting already holds for the female birds; see also the diary notes for 13 and 14 April, 1926 and 3 April, 1927. From a biological standpoint it is logical that that movement, which is most used to attract the other sex, is the first to awake the jealousy of rival birds. The behaviour of the human being in this respect forms a fine example.

It was stressed several times already that the biological significance of the nesting ceremony is that it gives the male a means to attract the female and keep her with him. All my observa tions point to the fact that as to this interpretation there can be no doubt. The male's skipping, especially when during its second phase the breast is pressed on the ground, has already the meaning to attract the female. The male constantly turns his strikingly coloured hind body in her direction, and she may be said at least to be influenced by him, in many cases directly to be allured. As soon as he begins scraping it wholly looks as though she has difficulty in remaining at a distance. Her behaviour is well described by Brock, who tells how the female gradually approaches the spot by short and indirect stages, how the male rises from and the female sits down in the scrape and how the female begins nesting now. He also calls attention to the fact that the male, on all such occasions, or when scraping near a female, takes pains to maintain his back to the view of his prospective mate, and that this position is not mere accident is shown by his occasional scraping or standing in such an attitude with his back to a strong breeze - a position of discomfort avoided by all birds under normal circumstances." But not only Brock, also Selous, Rinkel and Brunhilde Laven agree that the skipping and scraping male takes care to direct his back towards the female. Not only Brock, but also Selous and Rinkel agree that this male action has an alluring influence on the female. Brunhilde Laven's description (p. 22 - 23) leaves some doubt whether she has fully understood this strikingly alluring function of the male's nesting on the females, but, nevertheless, she must have understood that it has something like such a function, otherwise she cannot say: "Da das Männchen beim Scheinnisten meist bestrebt ist, dem Weibchen sein Hinterteil mit dem auf- und abklappenden Schwanz zuzukehren, kommt dieser Handlung wahrscheinlich Signalbedeutung zu"15.

Though, therefore, there is general agreement as to the alluring effect of the male's scraping on the females it is strange that the biological significance of the scraping action has never

${ }^{15}$ Since the scraping (nest-making) male usually tries to turn his bottom with flapping tail to his female, the action is likely to have a signal function. 
been clearly expressed. Rinkel's whole description gives the impression that he supposes the pairs to be formed especially through the copulatory act (p. 128 - 129), nesting apparently would be of no other use than showing the female the place of the scrapes (p. 129'); this is the stranger, because at other places Rinkel appears to state that pair formation results from "invitations" of the male (p. 130 and 131). 1 think the point is that Rinkel had difficulty in realizing the fact that a special action could be needed to join the mates and keep them together. Brunhilde Laven says hardly anything on pair formation, but her introduction to the chapter Display is clear enough. "Der Kiebitz lebt nach meinen Beobachtungen bisweilen, aber nicht immer in "Keinehe" (Heinroth), ein Männchen hat gelegentlich mehrere Weibchen. Darum ist es nicht gut möglich, bei dieser Art in Strenge von einer Paarbildung zu sprechen und sie den Lorenzschen Paarbildungstypen einzuordnen. Eine Paarungszeremonie ("Verlobung") fehlt dementsprechend, und eine Scheidung in "Vorbalz" und "Nachbalz" (Laven 1940) ist auch nicht möglich. Das Endziel der ganzen Balz ist vorwiegend die Begattung"16. This short introduction contains a bad representation of the actual facts.

Though the male lapwing has strongly developed polygamous inclinations it would be wrong to say that actual pairs are not formed. The formation of these pairs is made possible, because the male has a means to allure a female viz, by performing the nesting ceremony. There is neither pair formation through copulation, as Rinkel supposes, nor an absence of pairformation, as Brunhilde Laven would make us believe. The first and foremost significance of the nesting ceremony is to form and maintain pairs. This series of activities is therefore wholly comparable with that described by Huxley (1914, p. 516-517) for the grebe.

\section{b. Stick throwing and nest building.}

Few courtship activities of birds have received more attention from the side of countrymen and - lovers than those of the lapwing and this holds especially for that series of activities we have termed "nesting" and most of all for the third phase of this series: stick throwing. Kluyver, once meeting a friend-gamekeeper, asked him whether his companion had married already. His answer was: "Yes, he is already throwing stubbles". References to the action are to be found in several scientific, semipopular or popular descriptions of the bird's habits and I first intended to quote them here. As they do not more than simply describe the throwing, however, without going into any further detail I think it better to omit their quotation and to proceed dealing with the literature containing fuller descriptions. It is interesting to add, that it follows from Selous' description that, though he saw the movements indicating "throwing" he did not actually see the grasses and rootlets themselves, so that he reflects about the meaning of the movements observed, without knowing that his supposition was really a fact.

It follows from the foregoing pages that scraping leads to the formation of a scrape and it is evident that stick throwing must serve the purpose of building a nest from the scrape in question. Already Selous was aware of the fact that from "rolling" "just such a little round basin in the sand as the eggs are laid in may be formed. No eggs, however, were ever laid here, whilst the bird was afterwards to be seen rolling in other parts". Brock describes how

${ }^{16}$ The lapwing lives according to my observations sometimes, but not always in "Keinehe" (Heinroth) = not mated, a male occasionally has several females. For this reason, it is not quite possible to speak in this way of the strength of a pair formation, and to classify it into the Lorenzian types of cohesion. A mating ceremony ("betrothal") is missing, and a separation in "Vorbalz" and "Nachbalz" (Laven 1940) is also not possible. The ultimate aim of all courtship is predominantly copulation. 
the male may be seen to pluck from the soil stubble's and roots and to jerk "them backward over the shoulder in a haphazard manner, careless whether they fall in the scrape or, which is quite as frequent, outside it". "Thence he gradually steps forward, a pace or two at a time, continuing to pluck straws and dispose of them in the previous way". "It is in this manner that the hollows or "false nests" are formed, and each male in the course of the days elapsing before mating makes a number of such, usually in groups of two or three together, in which he works at intervals daily; and it is in one of these scrapes that the eggs are ultimately laid". According to Rinkel the male makes many scrapes without the female participating and he regularly uses some 3-4 scrapes at the same time; after some days others may be added, but old ones be left. Some males are little bound to definite scrapes. They sit down here and there, skip a moment, perhaps also scrape, but if one looks after their scrape one does not find it, and apparently the bird sat down in some depression. Such depressions as a rule are not considered scrapes by the approaching female and simply passed by. Brunhilde Laven tells she counted in both seasons she studied the birds about 50 scrapes in an area where only 4 males were present. "In Durchschnitt ergibt das je Männchen 12 bis 13 Nester"17 (p. 25). She also states, however, that the female may nest alone and that shortly before egglaying male and female may make scrapes in each others neighbourhoods so that it is not clear from her description whether it is impossible that females should have taken part in the production of this great number of scrapes. According to Brock, however, the female, "so far as I have seen, does not initiate such scrapes on her own account, although she later helps to deepen and line one or two previously formed by the male", and after Rinkel, too, the female, though able to scrape, never makes a scrape herself. I, personally, hold it with Brock and Rinkel, but the question should be restudied. If it is true that the female does not initiate scrapes herself Brock is right in saying that "the exact situation of the nest is thus primarily dependent on the choice of the male bird - a condition of affairs somewhat unexpected." On the other hand, the role of the female in transplacing the territory must be remembered. It may show that the female is able to make a scrape herself, if the males scrapes do not contend her. As the male makes so many scrapes this will rarely occur. "Die Stellen, die, die Männchen (male)(male) sich zum Scheinnisten aussuchten, erkannte im Sumpf auch das menschliche Auge als geeignet zur Anlage eines Nestes. Denn ausser auf den Bulten oder wenigen, etwas grösseren Flächen stand überall Wasser. So lagen die Spielnester zumeist auf mehr oder weniger grossen Bulten. Auf den grösseren Flächen im Sumpf lehnten die Tiere die Nester mit Vorliebe an irgend einem hervorragenden oder in der Farbe abweichenden Gegenstand, z.B. einen dürren Grasbüschel, einen kurzen Stock oder einen Kuhfladen". "Das Spielnest entsteht auf bewachsenem Boden dadurch, dass ein Männchen das Gras und Moos durch sein Sich Drehen und Scharren teils beseitigt, teils zur Seite drängt. So entsteht eine Mulde. Kehrt der Scheinnister nicht mehr zu ihr zurück, dann verfälllt sie bald oder wächst wieder zu. In der Regel benutzte ein Männchen häufiger ein und dieselbe Mulde zum Scheinnistung zumal im Sumpf nicht allzuviel Auswahl an geeigneten Stellen vorhanden war. Demzufolge entstehen schöne runde Mulden von der Grösse des späteren, Nestes (Brunhilde Laven, p. 24)”. Auf den Sandwiesen sind die Scheinnester. schon nach wenigem Scharren und Sich Drehen ganz ausgeprägte Mulden (p. 25) ${ }^{18}$. According to Stanford the "false" nests are considerably larger

\footnotetext{
${ }^{17}$ On average, this gives 12 to 13 nests for each male.

${ }^{18}$ The places which to the males seemed good nesting places are also recognized by the human eye as suitable for the formation of a nest in the marsh. For besides the bumps or a few larger surfaces, there was water everywhere. The play nests were mostly on larger or smaller bumps. On the larger surfaces of the swamp, the animals were fond of leaning the nests against any striking or differently coloured object, e.g. a small pile of dry grass, a short
} 
and deeper hollows than the nest selected for the eggs, which suggests that they are used on numerous occasions for the same performances. I do not know in how far this statement is right. The nest grows out of this scrape by stick throwing. This takes place by male as well as female when they step out of their depression when scraping together or singly. In walking slowly away from the nest the bird in question takes up straws, small sticks, etc. and throws them with a sideward backward jerk of the heads now to the right, then to the left, beside or behind him, so that the first straws fall down in the scrape, whereas the later ones do not. Throwing sticks beside him is especially shown by the bird when in close proximity of the scrape, throwing behind him occurs especially after having walked somewhat farther away. The bird therefore in throwing must, be influenced by the situation of the scrape.

Nevertheless, a greater number of straws certainly fall outside than in the scrape, a fact confirmed by Brock, Rinkel, and Brunhilde Laven. Brock says the bird jerks the stubbles and roots backward over the shoulder in a haphazard manner, careless whether they fall in the scrape or, which is quite as frequent, outside it. "Exceptionally she so behaves, when standing facing the scrape, thus dropping the nest material in a direction contray to the right one. In all their nestbuilding activities, in fact, both sexes behave in a strangely haphazard way, as though quite unconscious of what they are about". Rinkel says that as a result of the stick throwing those straws, which are to be found up to about I metre from the scrape, are gradually thrown closer by; those grasses, which by accident fall in the scrape, are, however, scratched out during the first scraping again, till the appearance of the first egg brings a change, see below. Brunhilde Laven, finally remarks: "Durch das Schleudern beim Abgehen können einzelne der nach hinten geworfenen Hälmchen in die Mulde fallen, die Mehrzahl der Hälmchen fliegt aber vorbei. Es kommt auch vor, wenn das Tier nicht gradlinig vom Nest geht, dass die Hälmchen eher von der Scheinniststelle weg als auf sie zu geschleudert werden"19.

Stick throwing results in bringing the nesting material, though from a short distance only, near the scrape. We may ask how it is possible for Vanellus to build a nest when there is no nesting material in the immediate neighbourhood. Brunhilde Laven states: "Ihre Auskleidung richtet sich nach dem in der nächsten Umgebung vorhandenen Material (dürre Grashalme, Stöckchen, Blätter usw.)" If such material is not available, however, the bird may pluck the material himself. I have seen a female lapwing busily engaged in throwing backward the long flower stems of Plantago, which were bitten or torn off the plants in rapid succession; when inspected, the nest appeared to have been built chiefly from these stems with their flowers. This, actually, also follows from Brunhilde Lavens own remarks given further below.

There can be no doubt this stick throwing, when performed by the male after scraping, forms part of the series of actions we have called the nesting ceremony. The scraping action is

stick, or a cow's dung. "The play-nests on overgrown ground are formed by the fact that a male partly removes the grass and moss by turning and scraping, and partly pushes it to the side. This creates a pit. If the producer no longer returns to it, it soon fades or becomes overgrown again. As a rule, a male used more frequently one and the same pit for scraping, because in the swamp not too many suitable places were present. As a result, beautiful round hollows arise of the size of the later nest (Brunhilde Laven, p. 24)". On the sand meadows the pseudo-nests became even after little scraping and turning very pronounced depressions.

${ }^{19}$ By throwing while walking away, some of the grass thrown backwards can fall into the pit, but the majority flies by. Sometimes, when the animal does not go straight from the nest, the grass may be thrown away from the pseudo-nest rather than towards it. 
invarably (or almost so) followed by stick throwing and the styleful way in which throwing takes place at once characterizes it, in fact, the whole nesting ceremony- as a display action. We cannot avoid the conclusion then, that nestbuilding in a symbolized form has become woven into the display actions, as is the case in more birds.

On the other hand this stick throwing finally results in the formation of a true nest. After the observations especially of Rinkel and Brunhilde Laven there seems to be little doubt (as was, in fact, always supposed) that one of the male scrapes is destined to contain the eggs and that it is the female which "chooses" it, see Rinkel, p. 133 and Brunhilde Laven, p.23 and p. 3235. This scrape grows out to a more or less well build nest in a very short time and as all stick throwing takes place in the styleful way - walking away from the nest and jerking the straws over the shoulder - there can be no doubt that stick throwing may help to build a nest. Moreover, each time the egglaying or brooding bird leaves the nest, thus, in moments when other species of birds would truly build, stick throwing may be performed in just the same characteristic way. This means that, apparently, a symbolic nestbuilding takes place when ordinary building should go on. The facts indeed, is that the "ordinary" way in which Vanellus (as well as a number of its relatives) build is the "symbolic" one: not by taking up grasses or straws and carrying them to the nests but by throwing the material backward over the shoulder. Also the true building takes place in a symbolized form. Only once did I see a female lapwing take up "nesting material" from the ground and walk a certain distance with it, when it was dropped again, but not in or near the nest. It proved to be a lapwing's primary feather! We saw, however, that those straws which fall in the scrape may be scratched out again by the scraping bird. How is it possible, then, that from this symbolic nestbuilding a nest is formed? I myself have never well understood this, but Rinkel's and Brunhilde Laven's observations make it quite clear. It is possible, because, as soon as the first egg appears, scraping is discontinued, whereas, at the same time, nestbuilding gradually takes a somewhat other form and from throwing the straws backward becomes a replacing them. It should be observed, however, that the Oystercatcher after Van Beusekom et al.'s observations (1930, p.52-55) many scrape sand backward each time when it is going to sit down on its eggs for incubation.

This replacing of the straws is described by Brunhilde Laven in the following way. "Es ist dieselbe Handlung wie das Schleudern, nur wird sie im Sitzen auf dem Scheinnist ausgeübt. Auch in den Pausen zwischen den Scharrperioden nimmt das Männchen Hälmchen auf und wirft sie mit nicht ganz so energischem Ruck wie beim Schleudem im Abgehen zur Seite. Später wird die Bewegung ganz ruhig, das Hälmchen wird langsam im Schnabel von vorne, wo es aufgenommen wurde, zur Seite geführt und auf den Nestrand gelegt. Oft hat es auch den Anschein, als ob das Tier das Hälmchen an der Seite unter sich schiebt. Dadurch entsteht später die Auskleidung der Nestmulde". And further on: "Die Hälmchen können aus der Nestumgebung ausgezupft werden, meistens aber werden lose Hälmchen aufgenommen, die z. T. durch das Schleudern in Nestnähe gekommen sind"20. Rinkel's description contains

\footnotetext{
${ }^{20}$ It is the same action as throwing, but it is exercised sitting on the pseudo-nest. During the breaks between the periods of scraping, the males also pick up straws and throw them to the side with less energy than during throwing. Later, the movement becomes quite calm; the straw is slowly taken in the beak from in front of the bird, where it was taken, to the side and placed on the margin of the nest. It often appears as if the animal is pushing the straw at its side underneath the bird. Later, this forms the lining of the nest cavity. The straws can be
} 
about the same facts. The nesting material is collected in the immediate surroundings of the scrape and finally lands more or less accidentally in the nest. As soon, however, as the first egg has been laid we see the female busily engaged, standing or sitting, throwing straws in the nest. As a rule the scrape is wholly covered at the end of the first day already. We observe, however, that a breeding bird every time haalt naar zich toe again some straws, to work them below the eggs. The description of Brunhilde Laven (p. 22) refers to the male, that of Rinkel to the female. These descriptions allow us to conclude that a sharp difference between throwing and replacing the straws does not exist and at the same time that throwing straws backward over the shoulder with a sudden jerk of the head apparently represents an exaggerated replacing of the straws from before the bird to beside it. In other words, the styleful nestbuilding, which clearly represents a ceremony, is an exaggerated gradation of the true nestbuilding, which itself, however, contains these same exaggerated elements of jerking or replacing the material backward. It is interesting in this connection to read the trains of thought of Selous (1902), who concludes just the opposite viz, that nest-building has grown out of the half purposive throwing movements.

Both Rinkel and Brunhilde Laven stress the fact that the nesting ceremony is first chiefly performed by the male and that the role of the female in participating in it develops only gradually. I assume that these observations in the main are right, because both authors write this independently; more over Selous (1902, p. 136) gives a remark to the same extent, and Brock (p. 301) states that many days may elapse before the female comes up to the scraping male. Again, somewhat furtheron, Brock states: "About a fortnight after the commencement of courting and scrapeforming on the part of the males, and some three weeks before laying begins, the females at length begin to show some response to the hitherto ignored advances of the males". Rinkel (p. 133) says the female allows the male to copulate only from about one week prior to laying her first egg, and at the same time she begins showing a greater interest in the place of the scrapes and in scraping of her own without having been stimulated by the male. A number of scrapes are regularly visited by her. Brunhilde Laven's description (p. 22 23), though not quite clear to me, states the same: the nesting of the male himself (apparently his scraping and stick throwing) is only gradually developed, it is gradually intensified, replacing nesting material takes place after a certain period only, and only when the latter stage has been reached the females begin showing interest in the male's nesting ceremony. "Hat das Weibchen in dieser Weise einige Male am Scheinnisten teilgenommen, dann scheint es einen Impuls zum selbständigen Handeln empfangen zu haben. Denn ohne Veranlassung durch das Männchen beginnt das Weibchen nun auch zu scheinnisten. Irgendwelche Unterschiede zwischen den Scheinnisthandlungen von (male) und Weibchen waren dann nicht mehr festzustellen. Doch bleibt das Weibchen zwischen den einzelnen Scharrperioden manchmal länger flach auf der Stelle sitzen, ausnahnsweise bis zu einer Viertelstunde, und verlegt dabei immerfort, was das Männchen nicht so häufig tut"21. And further on (p. 24) she writes: “.Die Scheinniststimmng des Weibchen ist lange Zeit schwächer als die des

plucked out in the nest environment, but mostly loose straws are picked up, some of which have come close to the nest by the throwing.

${ }^{21}$ If the female had participated some times in pseudo nest-building, it seems to have received an impulse to act independently. For without motivation by the male, the female now begins scraping. Any differences between the scraping of male and female were no longer visible. However, the female remains between the individual periods of nest-building sometimes longer sitting on the spot, exceptionally up to a quarter of an hour, and always replaces material which the male does not so frequently. 
Männchen. Auf das Weibchen muss also längere Zeit der Anblick eines scheinnistenden Männchen einwirken, ehe der Trieb zur Ablösung durchbricht"22.

I suppose that this gradual change in the behaviour of the female is restricted to the very first pairformation in the seasons when the female is always somewhat behind when compared with the male, see under Territory. Somewhat later in the season (and my observations have chiefly been made later) this difference between male and female is, I believe, absent. I further think that Brunhilde Laven's statement that even the male developed his nesting ceremony gradually shows that it was rather due to the coldness of the early season than to the fact itself that pair formation was only just beginning. Such a distinct gradual change in the courtship behaviour of the male during pair formation is certainly not the rule from somewhat later in the season on. I suppose Brunhilde Laven has been too much influenced by Laven (1940) on this points and Laven himself possibly by Lorenz' views. I further think it possible that Brock has somewhat exaggerated the later beginning of the female and that Rinkel may have been influenced in this respect by Brock. On the other hand, when there is evidence from so many sources it is clear I myself should not underestimate the importance of the gradual development.

I stated already that Rinkel and Brunhilde Laven's observations leave little doubt that it is the female who chooses out one of the many scrapes. According to Rinkel some few days before the first egg is laid she may sometimes be seen sitting in the scrape for a short period of time. Even one day before the egg is laid she may still visit several scrapes; evidently, then, her choice has not yet been made. Rinkel is of opinion she lays her egg simply in the scrape that is just visited when the first egg is going to appear. Brunhilde Laven's observations on two females (p. 31-35) show that the female chooses her scrape independently of the male and further that she may be seen sitting in the scrape a short time before the egg is laid. This, together with Rinkel's observations, may show that the female may either make her "choice" more or less accidentally or at least at the last moment, or that she may make it some time beforehand. Also Brunhilde Laven's remarks (p. 25) on the scrapes and their nesting material point to the probability that some scrapes may be given preference beforehand. "Die Mehrzahl (der Scheinnester) war von gleichem Aussehen, d.h. ohne auffallende Auskleidung, was auf gleichmässige Benutzung schliessen lässt. Nur einige waren besonders schön mit dürren Orashalmen ausgekleidet und wurden die späteren Brutnester, doch konnte das nicht

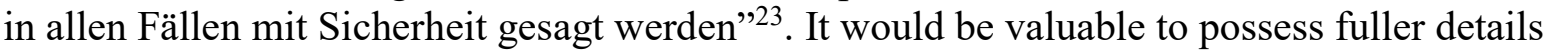
in this direction.

\section{Copulation and stiff attitude.}

\section{a. Copulation.}

\footnotetext{
${ }^{22}$ The pseudo-nest-building sentiment of the female is for a long period weaker than that of the male. The female must therefore be exposed for a long time to a pseudo-nest-building male before here nest-building instinct is aroused.

${ }^{23}$ The majority (of the pseudo-nester) was of the same appearance, i.e. without a conspicuous lining, which suggests uniform use. Only some of them were particularly beautifully lined with dry grass straws and became the later breeding nests, but this could not be said with certainty in all cases.
} 
It is a striking fact that the male lapwing never tries to copulate with the female when she is in close proximity, e.g. after stick throwing together with her, but always when she is some distance away. He has therefore always to cross a certain stretch when copulation is going to take place and this crossing is done by flying and hardly ever by running up to her. In many cases he does so after having been engaged in courtship flying or in an aerial combat, and in such cases he alights directly from the air on the back of the female. But copulation may follow his stay on the ground a short distance away as well and in that case the male flies up to the female in a straight line close above the field. Its course is straight because the bird directs itself towards a certain aim. For the same reason the flight is rapid, quite rapid I should say. In many cases it may therefore be recognized beforehand as the flight leading to copulation. If, however, the male wants to chase his or another female, or another male, I think the flying up of the male to the other bird does not differ in the least from the flight leading to copulation and I therefore do not consider this flight as something like a preliminary to it. I stress this, because Rinkel describes it as such, a proceeding with which Brunhilde Laven too does not agree.

Copulation itself is described by Brunhilde Laven (p. 23). According to her a male "fliegt von hinten her oder etwas seitlich das am Boden stehende Weibchen an"24. But as the male may fly up to the female from anywhere in the field or the air and as he flies up in a straight line he must reach the female from all sides. Rinkel may therefore be right when saying that the female places herself in the direction of movement of the male, with her tail towards him. I myself have apparently overlooked this. "Meist duckt sich dann das Weibchen etwas, d.h. es zieht den Hals ein und stellt ihn mit dem Rücken und schwanz in eine Ebene ${ }^{25}$ ". Rinkel says her wings stand off from the body a little and her tail is somewhat lifted. "Bei der Landung auf dem Rücken des Weibchen rüttelt das Männchen heftig mit den FlügeIn, bis es, mitbeiden Läufen auf dem gelegentlich ebenfalls kurz flügelschlagenden Weibchen ruhend, ins Gleichgewicht gekommen ist, ohne den Schnabel zu Hilfe zu nehmen. Dan drückt es seinen Schwanz seitlich abwärts, das Weibchen) den seinen etwas gedreht nach oben, so dass beide Kloakenöffnungen auf einander gepresst sind. Das Männchen fliegt dann vom Weibchen gleich in die Luft, oder es kann taumelnd seitlich am Weibchen abgleiten und erst nach kurzer Landung aufdem Boden hochgehe"26. Flying away right from the female's back probably occurs not often, as a rule the male leaps to the ground; in my diary notes I find under 18 April, 1926, that the male flew straight away from the female's back to start songflying; but I do not remember how often such flying away instead of leaping to the ground took place.

On rare occasions the male may copulate after running instead of flying up to the female. I do not remember anything there about, but in my diary notes for 1925 find under May 16 that I saw copulation taking place after the male had reached the female by running up to her. It

\footnotetext{
${ }^{24}$ flies from behind or slightly from the side to the on the ground standing female

${ }^{25}$ Usually, the female ducks something, i.e. it pulls the neck in and brings it in one line with its back and tail

${ }^{26}$ During the landing on the back of the female, the male shakes his wings violently, with two feet on the occasionally also shortly wing-beating female, until he has come into equilibrium without the aid of its beak Then it pushes down his tail laterally, the female turns here tail slightly upward, so that both cloak openings are pressed on each other. The male flies then from the female right into the air, or it can slip staggering sideways from the female and fly into the air only after a short time remaining on the ground.
} 
took me long to realize the striking fact that the male always flew up to the female for copulation, and I therefore cannot say how often running in stead of flying up occurred. Compare also my remarks below when dealing with the male's stiff attitude. Brunhilde Laven (26 and 27) says that though it is the rule the male flies up to the female, she observed some times a male running up close behind the female and spring on her back with a short wingstroke. I conclude from Rinkel's paper (p. 120, at two places) that he has now and then seen the same.

Pre- or post-copulating ceremonies are absent. For though copulation often follows the songflight the latter is no necessary preliminary. Copulation may presumably follow each action which succeeds in raising the level of sexual excitement to such a height that it may run smoothly; it is logical to assume that internal influences alone may suffice in many cases. In fact copulation may follow song-flying, or fighting, or the simple returning after some lapse of time. The stranger is the fact that it never follows the nesting ceremony, or rather its last stage: changing places and stickthrowing, see page?. It was already mentioned that a short straight flight to the female seems more or less essential, but I cannot call this a precopulating ceremony either (see, however, page 38). Though the nesting ceremony often follows copulation it neither can be called a postcopulating ceremony, for each other action can now and again follow pairing as well, and, moreover, "nesting" follows copulation indirectly only, as there is nearly always a shorter or longer run (to the scrape) between the two actions.

Brock's statement that immediately following coition "the female proceeds straight to the scrape, and works in it with energy and thoroughness hitherto unequalled, the male frequently taking his place in a neighbouring scrape" is false in so far the proceeding of coition is mentioned. I suppose that he did see such a behaviour once (though I did certainly never see it) and that he generalized his observation too quickly. It may also be that he took the male for the female. Therefore, his following statement is not right either. "From the facts available it would appear that the scrape used by the female after coition is the one which is destined to contain the eggs; in some cases, at least, this is certainly the case, and it is probably the general rule". Compare also what was stated about the choice of the nest in the foregoing chapter already. Brunhilde Laven's remark: "Die Kopula ergibt sich oft ohne vorausgegangene, andersartige Balzhandlung, bisweilen im Anschluss an das Scheinnisten des Männchen" 27 gives also a false impression, for copulation never follows the nesting ceremony directly. If a female comes up to the scraping male and changing roles and throwing straws follows, the birds will never close with copulation. And if the female does not come up to the male the latter may, again and again, try to allure her by scraping and eventually finish by throwing, but he will never fly up to her to copulate.

Copulation may take place many times a day. The lapwing differs in this respect much from the former bird I studied the grey heron. Whereas in the heron, copulation takes place some few times a day for a very short period only the lapwing may copulate many times a single morning and continue thus for a number of days, compare my diary notes for 14-18 April 1926, when the male copulates at least 4, 7, 4, 7-8 and 4 times respectively during the hours of observation. Brunhilde Laven mentions a male which copulated 8 times within $15^{1 / 2}$ hours

${ }^{27}$ Copulation often results without a preceding other courtship behaviour, sometimes following the male's pseudo-nest building. 
with the same female, which on that day was laying her second egg. She assumes that not all these copulations lead to real transmission of sperm, but I see no reason for doing so.

Above I cited Brock to the effect that the females begin to show some response to the hitherto ignored advances of the males about a fortnight after the commencement of courting and some three weeks before laying begins. Brock further states that the scraping antics become less frequent a day or two after male and female have joined, when the two birds "are content to remain quietly in each other's company, usually at no great distance from the scrapes". Thereupon, coition would take place a few days before egg-laying, and this would be accompanied by a renewed activity of nesting, now especially shown by the female. If Brock were right, the male lapwing would court some two weeks without his female showing interest, then during some few days show a joined courting (nesting) then for about two weeks show no activities, where after copulations and within a few days egg-laying would start. If all this would be really true, the lapwing would show just such an intermezzo of quietness within the height of the pairing season as is found in territorial song birds, especially Howard's buntings. I somewhat doubt the rightness of this statement, as long as it is not affirmed by other observations, but the earlier arrival of the lapwing on the breeding grounds in South England does not exclude the possibility. According to Rinkel the first copulations take place about one week before the first egg is laid, generally not sooner than 2 $\sim 3$ weeks after the arrival of the birds on the breeding grounds. There would thus be a period of 3- 4 weeks between the arrival and egg laying and this is - for Holland - certainly nearer the truth than Brock's statements. Rinkel, just as Brock, states that no copulations occur prior to a short time (according to him one week) before egg laying, and according to him the lapwing differs in this respect from the blacktailed godwit, the oystercatcher and the redshank, which copulate from some days after their arrival onward. Personally, because I directed my attention chiefly to the courtship activities and very little to egg laying and breeding, I cannot give evidence of the contrary, but I am convinced that so much depends on the air temperature and on the physiological state of the birds in question that it is dangerous to generalise. On the other hand, because Brock and Rinkel confirm each other, Rinkel may be right that the female lapwing permits copulation relatively later than the other Limicolae mentioned and this in itself would be of much interest, as the lapwing is a much "harder", more cold-bearing species than the others.

Whereas the female grey heron does not seem to copulate after the last egg has been laid by the female, lapwings still may copulate during egglaying and brooding. The female mentioned by Brunhilde Laven, copulating 8 times in 151/2 hours, allowed copulation 40 minutes before laying its egg, and, again, 10 minutes after laying. A female lapwing still copulating during incubation is mentioned in my diary notes for 16 May 1926, see the second part of this paper. Rinkel states the female may still allow copulation when actions incubating the eggs for more than a week.

Rinkel describes as one of the female actions the refusal to copulate. If the female does not want the male to copulate she places herself crosswise, diagonally on the direction of movement of the approaching male, sags a little in the heel and foot joints and stretches her neck horizontally, keeping her bill straight forward. The wings are pressed against the body. The male, according to Rinkel, reacts on this attitude by making himself high. Rinkel gives a clear drawing of both male and female at this moment. I myself have never seen this stiffening of the female and Brunhilde Laven in her Postscript says she saw it not always in this situation, but only rarely. Apparently, however, she did see, though not describe it. I do 
not understand I overlooked this stiff attitude of the female, though observing hundreds of copulations, but it is also difficult for me to believe Rinkel is mistaken. Rinkel draws attention to the fact that the stiff attitude of the female corresponds to (agrees with) the stiff attitude of the male to be described below, but I think we should not follow him in this comparison, see below.

\section{b. The male's stiff attitude.}

It was just described how the female according to Rinkel may refuse copulation by showing a stiff attitude; we saw that the male reacts on this attitude by making himself high. Though it never attracted my attention that the female refused copulation by making herself stiff so to speak the encounters of male and female Rinkel describes can rather often be observed. Now and again we see a male fly right down to a female as if copulation will follow. Instead of that, however, we see that he alights beside her, keeping his head upheld, his crest high and his breast protruding, his feathers puffed out so that he looks large, a behaviour which in my mind denotes anger. In such a case a very strange attitude generally follows. The bird stretches head and neck horizontally and makes himself so-to-speak quite stiffy thus walking in close proximity to the female, with stiff steps. I noted on one occasion that the tail seemed to be bent down and spread out during the performance, but I am not sure about this. Mostly the stiff attitude, just as the copulatory act, is followed by the run to the scrape and the nesting ceremony. Rinkel says the stiff attitude of the male differs from that of the female in the attitude of the wings: the male, in walking away from the female, according to him, enlarges the dark green iridescing surface of the wing which is turned towards her; seen from behind he makes a lopsided appearance. I must have quite overlooked this.

Though after some seasons I felt much at home with the rest of the lapwing's doings I have always retained some feeling that here I failed to understand the bird. The possibility exists that in all cases in which the stiff attitude was shown the male had the intention to copulate, found the female unwilling and now reacted on her refusal by anger, followed by stiffening. I felt as though I saw the excitement seek in vain for an outlet and cause the body muscles to contract. But feeling is dangerous! As stated already I had no means to conclude beforehand from the actions of the female as to her willingness to pair.

In some cases, when her crouched attitude and flat horizontal back showed very distinctly that she was eager, or, at least, would not refuse the male to pair I knew copulation would follow. But in other cases it seemed to me that there was no change whatever in her attitude. I therefore remained doubtful as to the meaning of the stiff attitude. Rinkel states the male's stiff attitude not only follows a refused copulation, but often copulation itself. I do not remember this ever having seen, and Brunhilde Laven also does not mention it, but, on the other hand, I have difficulty in believing Rinkel could make this mistake, as it is much easier to overlook an action than to find it where it is not. This, together with Rinkel's observation that the male's one wing is somewhat lowered in front of the female, does not make it easier for me to believe that the attitude denotes the reaction on a refused copulation without more. I should add that on one occasion (16 April 1926)1 saw a male after long and wild song flying perform the stiff attitude when there was no female in his neighbourhood. It was followed by a short run to a scrape and "nesting" just as if a female were present. It may be that the impossibility to pair caused the stiffening here in just the same way as when a female refused copulation. 
Selous $(1902,1905)$ calls attention to a curious little run of the male by the side of the female and a little beyond her, once after copulation and once after rolling: "he rises and runs forward in a series of very short little precise steps, which have a peculiar character about them. His whole pose and attitude is, also, peculiar. The head and beak are pointed straight forward in one line with the neck, which is stretched straight out to its fullest extent, the crest lying flat down upon it". "In this strange, set attitude, and with these funny, little set, formal steps, he advances without a pause for some twenty or thirty yards, then stops, and, without leaning forward on his breast, elevates the tail, waggles it strongly from side to side with the same peculiar action as before and then flies off. There is no doubt Selous is describing what I have called the stiff attitude here. Selous says it is shown after rolling. Judging from what Rinkel states the first may be right, but the latter is probably not. In another place (p. 140) Selous writes the very marked and peculiar run with the set, rigid attitude precedes the rolling and this is quite right.

Brock says courtship in its usual from takes the following course. On catching sight of a female bird, or when the latter chances to settle somewhere not too far away from his usual stance, the male approaches her by means of a direct and rapid run. On arrival he stops, and describes a halfcircle close round her, his pose and gait peculiarly constrained and stiff: the head and neck are held out in line with the body and the crest depressed. He then, without further pause, stalks off stiffly directly away from the female, and makes for his nearest scrape, into which he instantly drops. He works now with exceptional and prolonged energy, pausing occasionally to pluck straws and grasses, and dropping them over his shoulder or by his side. As follows still better from his further description Brock considers the action we have called the stiff attitude as part of normal nesting ceremony. A slight variation of the courtship is when he approaches the female on the wing. In such a case, on settling close beside her, he momentarily takes up a very erect attitude, towering over the other bird, "his breastfeathers puffed out to their fullest extent, and the long crest inclined forward". There is no doubt from this clear description that its second part concerns the "state of anger" preceding the stiff attitude and the first part the stiff attitude itself, with the run to the scrape and the nesting ceremony. Of course, we can look upon this whole series of actions as representing one whole, but it would be illogical to do so, as we are clearly dealing with a number of actions and reactions of male and female, each with a different meaning. According to Brock's description the male shows stiffening after having run up to the female. I think I remember from my own observations having seen this more than once myself too. If the run in these cases would have represented the run preceding a refused copulation it would at the same time explain why I saw so few copulations after the male had reached the female by running instead of flying up to her, I just would not have realised that these runs had something to do with the intention to copulate, and, from this again, it might be concluded that copulation would be oftener refused when a run than when flying up precedes it. In this case flying up, contrary to what I was inclined to believe above, would have some stimulating effect as a pre-copulatory movement. Brock further describes the state of anger preceding the stiffening for the bird which had reached the female by flying, and not by running, I do not remember for certain whether the showing of anger only occurs after the male has reached the female on the wing and not when it has reached her by a run, but I think I remember anger may be shown by the male in both cases.

Brunhilde Laven apparently has overlooked the male's stiff attitude, as she does not mention it. It seems not quite impossible to me that her observations mentioned under "Bodenbalz" are partly concerned with what I have called male's anger. Attention should be drawn once 
more to the fact that according to Rinkel both male and female show the stiff attitude, the female according to him only when refusing copulation, the male after refused and nonrefused copulations. Moreover, the male according to him lowers one wing in front of the female, whereas the female keeps both wings pressed against the body. This looks as if both attitudes, except from partial resemblance, have little to do with each other. The bird should be restudied in this respect, as, in fact, in several others.

\section{Sounds}

Several of the lapwing's sounds have been described in the preceding pages. For the sake of clearness these are summarised. Moreover, some facts, which did not find a place as yet, are added.

The song of the male is described in the chapter dealing with the song flight. It is wholly absent in the female.

During air combats the males constantly utter the musical "keeéee-oo-weet", which is so characteristic of the true song, the next "weet weet" of the latter, however, being omitted. Brock's interpretation that fighting is accompanied by partial singing is therefore probably right and this fact corresponds to what we find in so many other species, especially of songbirds, which sing pieces of their song as an outlet for high emotional tension when fighting. Ground combats are never accompanied by this sound, which clearly belongs to the air. Birds fighting on the ground make a quite different sound, uttered by both male and female, see below. Females are never engaged in aerial combats and do not possess the musical keéee-oo-weet.

The male's sawing sound is mentioned in the chapter on the nestbuilding ceremony. It is chiefly made during what we called skipping and scraping and seems to be wholly absent in the female. As an exception it is made by the male on other occasions. It seems most likely that the sound may denote strong sexual desire.

The sounds which now follow and which are, generally speaking, innate to both sexes, can be brought to two groups.

One of this is rather one sound showing some variation than a group of sounds. It is the rapid "ee-ee-ee-ee, ect" or "tee-tee-tee-tee", made by a bird on the ground, when stooped at by a bird in the air. I believe this sound is chiefly made by the attacked bird, but I am not sure it is not made by the attacking bird as well. It is little heard during the breeding season, but constantly uttered outside it, when birds within the flock are harassing each other. It is one of the easiest identifiable sounds in moonlight nights, when it shows that the birds in the flock, just as during daylight, may be constantly quarelling. The same sound, possibly somewhat softer, may also be heard from the female when she is chased by the male, see under May 29 and June 5, 1927. I think it denotes fear then, but if so it would be strange if the attacking bird (at least outside the breedin season) would also make it. Nevertheless, we find just the same in the grey heron (Verwey, 1930, p.15). Generally speaking, the sound does not belong to the breeding season, but rather to flocking birds. I believe it even to be wholly absent in rival males which during the mating period are engaged in territorial ground combats. Such combats of two birds on the ground hardly ever occur outside the breeding season and I therefore do not know whether then the sound would also be absent. 
The second group of sounds, though attracting little attention in mated birds, contains the chief vocabularies of the birds during all the rest of the year. It centres round the well known "kée-weet", to which the bird owes its Dutch name, but shows an endless variation of duration and intonation. It may be drawn out so long that it nearly contains three syllables, but also be so short that it contains one. The accent may fall on the first half, but also on the second, with transitional stages between. Any description of' it must remain poor compared with its actual richness in variation. The sound is in the very first place used as callnote, i.e. as that sound which belongs to the group so well denoted as "Stimmfühlung" bei Heinroth. It is characteristic for many social birds as long as they live socially whether during flocking outside the breeding season, like the lapwing, or during colony life within the breeding season, as the grey heron and others with the result that they keep contact by voice (sound). Few groups of birds have this auditive contact so well developed as the Limicolae, and the lapwing makes no exception in this connection. It is quite striking that this "kee-weet", which so much attracts attention outside the breeding season, is so little made use of by mated birds, at least by the males. I think the reason is it develops and disappears together with social feelings, just as the song and other sounds develop and disappear together with sexual wants. In other words, the ordinary Stimmfühlung-sound "kee-weet" in the male more or less replaces the breeding time vocabularies and vice versa. This occurs in more species of birds, the Ryves mention it for the corn bunting (1934, p. 5-6). As stated above the sound may vary endlessly in intonation and duration and it would be worthwhile to study its many different meanings. The only fact which can easily be established is that, when very short, it denotes fright. It no longer consists of two more or less distinct syllables then, but of one, a rather harsh "kreet", the shorter and harsher the greater the fright, with gradual transition to the normal kee-weet. It may be regularly heard from birds taking to the wing before one in the dark or being taken by surprise in day light, also by birds just flying up before one during the day. A less loud "kreet" is even associated with each flying up of the birds, even if they are going to move a short distance only.

Whereas the male uses its callnote but rarely in breeding time the female uses it on many occasions though, still, she is probably much more silent during the breeding season than outside it. I told already that when the bird (at least, what I take to be the female bird) in early spring is flying around (I believe in search of a male) the sound is repeated at more or less regular intervals and rather monotonous. But it is also used as expression of emotion, e.g. when the bird observes her mate fighting or chasing, see page 65, or when in fear for cattle. It is more or less complaintive then and I think much resembles the anxious "kee-eet", uttered by both sexes when the young are in danger. The latter cry may be quite piercing. Probably when the bird is more or less depressed the call may sound like "keewt"; it is not very loud then. I am here referring to female A on May 13th and 14th, 1926, after the male had chased her.

As stated the male uses the callnote very little during the breeding season, at least during the period of pair formation; later, when the eggs or young are in danger, the question is otherwise, but I possess hardly any exact observations on this period. On rare occasions, the male may utter a distinct "kee-eet" during mating, however. The case has been described on page 16 and probably refers to a male, which is much longing for a female. I therefore think the utterance of the sound then comes forth from strong sexual desire. It is interesting to note that a sound which is so much used during the rest of the year may wholly disappear during a 
certain period, to be used as an outlet again under exceptional circumstances, probably of inner emotion.

\section{Summary}

We have become acquainted with the chief courtship activities now. The first and foremost of these is the song-flight, which is shown by the male only and is wholly absent in the female. It belongs to, in fact cannot be separated from the male's song, both together forming an entity. This entity of song and flight, like the song of songbirds, has the double function of outstaking and maintaining the territory, and of display towards females. Neighbouring or new males may be informed about the territorial boundaries, because the height of the songflight, containing the somersault and final part of the song, is especially made above the limits of the territory; that the flight has display function may be concluded from the fact that the male shows his song flying around the courted female for a long time in succession. Besides having territorial and display function the flight is much used for contending social needs, the males being fond of song flying in each other's company without bothering about territorial boundaries then. Finally the song flight is probably of value through its self stimulating influence, as it often leads to copulation.

The court performance the male indulges in the series of activities we have called the nesting ceremony, which consist of three parts, here named skipping, scraping and throwing. The chief function of this series of activities, which is especially shown by the male, is to allure the female and thus to bring and keep the birds together. It does not stimulate to copulation as "nesting" never leads to this. The first part of the nesting performance, skipping, is chiefly shown by the male and little by the female; she is able to skip, however. Scraping is chiefly performed by the male; the female regularly scrapes when allured by him, but rarely of its own accord, she is by no means persistent in it, and when scraping together with the male always stops it after very short time. Scraping, of her own accord was seen a few times only by me. On one of these occasions the female in question was probably alone, in the others, however, she was clearly stimulated through the presence of a rival. The alluring action of "nesting" is chiefly brought about by the skipping and scraping performances, especially the latter. Stick throwing is performed after scraping when the series of nesting activities as a whole is accomplished. Its chief function within this whole is certainly not nestbuilding, but display: a symbolised nestbuilding woven into the play actions. Stick throwing, especially after the first egg has been laid, has, however, also the function of the building of the nest; in this function it is performed by both sexes, and it may then get rather the character of replacing the straws than of throwing them. In this connection it is regularly performed of its own accord e.g. after brooding, just as the nestbuilding of other birds. The two performances, display and true nestbuilding, cannot be sharply separated. It is clear that the display function of nestbuilding, speaking evolutionarily, has grown out of the nestbuilding by an exaggeration of the movement of replacing the sticks from in front of the bird to its sides.

The third courtship activity shown by the lapwing is aerial fighting. It is restricted to the male and its chief function is to defend the territorial integrity. I do not think it has any display function, but it is used by the bird, just as the courtship flight, to content social needs. The ground fighting on occasions has also the function of maintaining the territorial integrity, but as it occurs in less serious form presumably in both sexes also outside the breeding season we do better not to reckon it to the courtship or rather the nesting time activities proper. Copulation takes place (nearly exclusively) directly from the air, the male flying up to the 
female and alighting directly from the air on her back. Pre-or postcopulating ceremonies are absent. Copulation may follow many different actions, courtship flying, fighting, but also the simple returning after some lapse of time; copulation is often followed by "nesting", but by many other activities as well. There is a strange attitude, the stiff attitude, especially (but not only) performed (by the male) after copulation is refused by the female. Its biological meaning is not clear to me. According to Rinkel the female has a special attitude denoting refusal of copulation.

We have found, then, that the courtship flight and fighting-are restricted to the male, and are missing in the female, and that of the series of "nesting" activities the skipping is inherent to both male and female, but performed by the female very little only, that the scraping is inherent to both sexes, but performed much more by the male than by the female, and that stickthrowing in the female has more nestbuilding, than display function, whereas in the male the reverse holds true.

Attention should here be directed to the fact that the female lapwing in breeding time, contrary to her mate, is a true ground instead of an aerial bird. Putting it in an exaggerated way one could say she hardly ever flies. But this holds only for those cases where she is not alarmed by man, cattle, crows or gulls, and where female rivalry plays no part, and such cases, of course, do not exist. It is striking, however, that about the only times she takes to the wing are those occasions on which she is alarmed and has to chase an enemy or to flee, or when there is so serious a rival, that she has to chase her. I think there are single days, when the birds are little alarmed, on which the female does not take to the wing once. I should add, however, that I once (June 5th, 1925) saw a female leave its nest by flying, apparently for no other reason than to bear away (in its beak) a small white parcel, certainly excrements. She returned to the nest at once, running, not flying back to it.

This observation may show that excrements are rather transported in flight than by running; I possess no more than that one observation, however. A further point of interest is the fact that the lapwing, at least medio April, 1926, seemed to be a typically diurnal bird, going to rest even before it grows dusky. I possess some very few observations only on this point, but they were quite striking and I therefore suppose them to be representative of the bird's behaviour during a longer period. They were made on 13, 14 and 16 April, 1926, when my birds, which had been quite active up to that moment, stopped their work at about 19.00 o'clock to sit quietly down behind a tuft of grass, thus protected from the wind. It would be interesting to know somewhat more about this behaviour, because the lapwing is so much of a nocturnal bird. Observations near Leiden in the autumn of 1941 gave me the impression that in dark nights the birds are quite inactive; it is wellknown that in moonlit nights they are constantly busy; it should be interesting to find out whether it is the mere quantity of light, which causes these differences, and what quantity is eventually of importance in this connection. Rain, at least if it falls after some period of dryness, influences their activity to a very large degree. This apparently holds for many Limicolae and is well known from, Numenius (“Regenpfeifer").

The fact that lapwings interrupt their brooding so many times a day, also in cases where man does not interfere with the bird's doings, has been stressed by others already, especially by Brunhilde Laven, so that I refrain from giving details. This inconstancy in breeding occurs in other species. too, apparently especially in Limicolae (Phalaropus: Jourdain (19xx), Avocet: Glegg (1925), Charadrius dubius: Tolman (1929), but probably in many other species as 
well: Kluyver (1933,p. 49) describes it for Sturnus vulgaris, where intervals of 2-10 minutes during incubation are numerous.

A lapwing, watching a crow or gull approaching though the air, as rule flies right away from the nest straight up in the air to meet the other bird. This seems to hold for both male and female. Also when leaving the nest to chase another lapwing the sitting bird may fly straight away from the nest. When the bird leaves the nest for a human being, however, it will generally leave it running and not flying. I do not know how the incubating bird reacts on the appearance of small mammals of prey (Mustelus, Putorius, Erinaceus). Cattle is reacted on by walking or flying (and stooping down on them) just before them in close neighbourhood of the, nest. I once saw a bird -female Z" on May 29th, 1927 - which was much agitated, because a horse approached her nest: she stood there on the meadow in close proximity to the big animal, looking obliquely up to it, and constantly calling "Keeweet". The horse laid his ears down and when the lapwing all at once ran a little way in his direction he brusquely turned around, as if to kick the bird! He then walked gradually away.

It was clear that the animal has formed a very unpleasant association between the presence of a calling lapwing in close neighbourhood and an attack and the observation well illustrated the effectiveness of the latter.

Rinkel says that when the cattle are brought into the meadows they destroy nearby all lapwing clutches during the first few days; after they have been in the field for some time, however, nearly all of the newly laid clutches remain intact. This, too, points to the effectiveness of the lapwing's behaviour towards cattle. 


\section{Second Part. Polygamy in the Lapwing}

Cunningham's statement, cited in the Introduction to this paper, so very true, may serve as an excuse that I begin this part by a lengthy summary of my observations in so far as they throw some light on the polygamous inclinations of the Lapwing. I cannot omit them, however, as they form the necessary base from which the facts for my conclusions have been gathered. Much to my own regret I omit all observations not dealing with polygamy and give the facts in very condensed form. Though this, again, may be displeasing to those readers who would appreciate to possess the full observations, I thought it better not to give fuller notes for reasons of space and want of time. Part of the observations of 1926 (28 March- 17 April) have been given in extenso in Dutch in (Verwey, 1927). Generally speaking I should not advise my readers to try and consume these diary notes as I shall refer to them where necessary.

May 24th - Twice seen how a male lapwing tries to assault a female, who defended herself violently, so that the combat even ended in the air. The first time another male, certainly her own, comes up and follows the invader. The second time the male certainly is again another than the husband, but this did not follow directly from the observations. The female, I believe both times the same one, is one which has been brooding a long time already and has left her nest for a walk.

May 25th - A male is very much agitated. He rolls, flies, fights, etc. But moreover he troubles two females. One of these is brooding and every time she walks from the nest, the male runs or flies up to her and follows her, she every time running away. Now and then they even come to fighting. Later the male even dashes down several times on her when she is brooding. The other female is sitting on a spare nest from which she now and then walks away. Here again the male dashes down on her while she is sitting or walking. - It may be that the whole procedure is nothing else than clearing the ground from other lapwings, for the male is very much agitated. The male probably had a female, with whom he was rolling, but I saw no copulation take place.

June 6th - Two females on their nests. A male is feeding in the neighbourhood of the right one and she fights once with him, flying straight away from the nest I believe. Also observed that this or another male tried to assault the female. [For female being assaulted see, however, next chapter under Discussion]

1926.

April 5th - A male comes flying to the foremost part of the meadow in front of me, where a female is feeding. The male begins rolling at some distance from her; I see how the legs trample the ground. Then he begins stickthrowing.

After some walking he continues rolling. This is repeated once more. Each time the male rolls the female approaches a little more. The second or third time she comes quite up to him and begins rolling and stickthrowing too. 
They roll a long time together. Now and then the female walks away. When he begins rolling then, the female runs up to him again and rolls with him again.

When they have removed a little, the male at once flies away towards the back part of the field. He comes down near another female. After a moment, however, he comes back again and copulates with the female, with whom he was rolling a short time before. At the same moment, I see how the male presses himself down: another male approaches wildly and dashes down on my male. He does not rise, the other comes down to the ground and now a furious combat begins. Both birds stand opposite each other with wings out nearly horizontally. Every moment they spring up against each other, the crests stand out straight into the air. The female sits still in the grass. The male who copulated refuses to leave. After short fighting, however, the combat is continued in the air, as normal. Then a third male comes. He seems to try to assault the female, who is still sitting on the ground. The result is that this male is taken up into the combat. The female flies away, after I believe-she kept off the intruder. The combat between the first two males is of long duration, for as is the rule one tries to come down and the other to prevent it. At last one of the males, I shall call him A, comes down not far from the place where male and female rolled together. He is quite excited: standing on the ground he now and then skips up and down a little with horizontallyspread wings. At first he changes place every moment.

After some time the bird walks to the back part of the field and I see that there is a female there. He remains in her neighbourhood; they feed. All at once this female copulates with another male (whom I shall call B) who came from still farther back. Male A does not react for what I can see and male B after copulating flies to the forepart of the meadow. I do not know what exactly happened in the meantime, but some moments later male B is sitting at some distance to the left of the female, the other male to the right of her. The latter approaches the female now and then rather closely and she sometimes seems to follow him. But all at once male B flies up to the female and comes down beside her, while she crouches down. He has his head high, his crest erected and looks quite angry.

A long time of feeding follows. Once the males approach each other closely, but they do not come to fighting again. Male A every time tries to remain in the neighbourhood of the female. I get the impression that the other male is constantly attentive and now and then walks in the direction of the other two when they are close together. Finally it becomes too dark to observe any longer.

April 13th - Morning: Male lapwing flies to a female and copulates, then flies away from her and begins rolling. He continues it for some time, flies to another place and begins again. Before long the female approaches; she is very attentive, walks up to the male and in his place begins rolling.

After some time of rolling both go on feeding. When after some time he has come into another corner of the meadow, he begins rolling again. And before long a second female comes walking up to him, to take up the rolling in his place. The first female is still in the other corner. They change rolling, then go on again. After some moments the male flies right up to the first female and copulates with her for the second time. I shall call this female A, the other B. After some feeding the male flies back to female B, to feed, rest and probably also "roll" in her neighbourhood. A long time elapses, during which the male now and then rolls and twice attracts female A, who then rolls with him. When the two females come into each 
other's neighbourhood and get sight of each other they are quite attentive, stretch their necks, but do not fight or otherwise.

Evening: Male and both females present. One female rolls when the male comes into their neighbourhood. Another male, who alights not far from both females, and rolls there, is not chased.

April 14th - Morning: Male and both females present. Shortly after my arrival female B chases female A, whereupon the male flies up to them and female B alights somewhat farther away. Male and female A feed together now, until he shows his courtship flight and alights, with raised crest, in front of female B. He runs away from her and both preen their feathers. Female A now walks in their direction and the male flies up to her, perhaps copulating in an unexpected moment, then running away and rolling. Female A approaches and then they roll together; finally they walk away each its own way. Some time elapses, during which the male flies now and then courtship with other males till they finally walk together again. All at once the male flies to female B, copulates, runs away from her and begins rolling. Female A walks at a small distance, she must have seen this, but goes on feeding. The male then starts flying again, next alights, walks up to the females, begins rolling, attracts female A, then rolls with her. After some walking or feeding the same is repeated. All at once, however, the male flies to female B, alights near her with his head high an his crest erected, turns around her, runs away, begins rolling, then goes on feeding. Both females are feeding too. Some moments afterwards the male starts rolling again, female B runs up, rolls with him, female A goes on feeding. Somewhat farther away the male rolls again, throwing, I believe, living, green grasses instead of straws when walking away. After some flying he returns to female A, copulates, runs away, starts rolling, etc., whereupon female A, instead of coming up to him, starts rolling ("treading" and "throwing") at a distance. He goes on feeding again but female A remains sitting, then goes on "throwing", till finally the male comes up and begins rolling close to her and female A continues "throwing". Finally male and female go on feeding. Male flies his courtship flight, returns to female B, alights in front of her, quite erect, then bends down, runs away, starts rolling ("throwing"), flies courtship, returns to female A, copulates (female B was sitting close by and looked on), runs away for some distance, starts rolling, till female A comes up and they roll together. After some flying and walking the male flies to female A, copulates, flies to the corner of the meadow and begins rolling there. A moment later the male and female A roll there together. Female B walked in close proximity to the copulating birds and went on feeding. The male now walks from female A right to female B, but passes her. Thereupon female B walks in the direction of female A, all attention, with head high.

As soon as the male sees this, he flies up to her, she flies away and he chases her. She alights not far from A, he chases her away, she again alights in A's neighbourhood, somewhat farther away. Female B looks towards A with head high; female A now rolls! The male alights in the neighbourhood of the females, then flies courtship and alights farther back on the meadow. Another male now alights close to female B, the male comes up and dashes down upon him, the other male flies away and alights somewhat farther away. My male alights towards the back part of the meadow.

Evening: Male and two females present, but they disappear on account of children, who are picking flowers. Female B returns to the centre of the meadow, female A more backward. The male chases another male. They dash twice over female B, who crouches. Male alights 
not far from female $\mathrm{B}$, the other male alights in the corner of the meadow. Then male runs rapidly to this corner and begins rolling at some distance from the other male. After some flying and walking, male and both females have taken their resting places for the night.

April 15th - Male and two females present. Male starts rolling not far from female B and after long rolling she finally comes up to him; during his "throwing" she goes on feeding, however. Female A now flies to another place of the meadow, the male flies up to her, copulates, runs away, starts rolling, she runs up to him, also begins rolling. Another male alights close by female B, so that our male approaches wildly; the other male flies a short distance, refuses to leave, our male now alights in the background. New male walks slowly into the direction of female B, then drives away a Redshank pecking at it. Female B runs up to him, chases him away. Our male in the background must have seen this, he is already present, dashes down on new male, who yields a little more. Our male now flies to female A, copulates, runs away from her and starts rolling. All at once female A runs in the direction of female B. The male dashes down twice on her and chases her away, he is angry! But again female $A$ runs to female $B$ and again the male chases her away. This is repeated a third time: before female A has reached her rival, the male has reached her and picking her drives her away. The male now alights between them, then chases female B some distance. After a short time the male starts flying with other lapwings, then flies to female B, copulates, runs away and begins rolling. Female B does not come up to him, he then walks in her direction and begins rolling again. After some courtship flying he alights on female A, copulates, flies away from her and begins feeding in front of me.

After some time he flies to female B, copulates, flies away again and begins rolling. When another male flies over, my male flies up; he alights near female B, head high, crest erected, runs away from her, starts rolling, whereupon she comes up to him. All at once he flies out of his depression and chases away female A, who had approached in the meantime. He walks away again, begins rolling (at least skipping) but female B does not come. He rolls a good while, then goes on feeding.

After a long time the male flies up, alights near female B, flies from there to female A, copulates, flies a short distance and starts rolling. Female A approaches female B too, but the latter flies at once away and alights at another spot in the neighbourhood. The male flies up and alights somewhat farther backward, whereupon female A runs to female B. But when the male comes up, female A returns; the male returns to the back. Another male walks in the direction of both females; our male comes up, dashes down upon him, they fight in the air and alight in each other's neighbourhood. Female B now runs to female A, but the male comes up and chases away female B, who returns. The male walks to the back. After some flying the male alights in front of female $B$, head high, crest erected; he flies away from her, in front of me. Then the male walks till he is not far from female B, starts rolling busily, the more so the more female B approaches; they roll together. When she walks away, he alights in front of me, then flies courtship. After some time the male flies to female B and copulates; female B awaited him bending foreward, head downward, back broad, flat and slightly raised. Thereupon the male walks a short distance away, skips now and then, next when female B goes on feeding - flies up and alights in front of me.

April 16th : 6.45-10.15. - Some time after my arrival the male comes back, alights on female A, copulates, runs a little distance and begins feeding. After some courtship flying he chased away female A; I then see that female B remains where A was chased away. The male alights 
near B, shows some courtship flying, alights again. Female A comes flying from the back tries to chase away B, but the latter alights again and the male comes up to dash down on female A and then alights between A and B. Again B is chased by A. I cannot exactly see what then happens, but female $\mathrm{A}$ is sitting in a depression and pecking around her, whereas $\mathrm{B}$ is very curious and turns around $\mathrm{A}$. The depression seems to have some meaning for the birds. The following moment, however, $\mathrm{A}$ is again pecking at $\mathrm{B}$ and driving her away.

The male is quite active (all males today!); his courtship flying takes no end; he is very aggressive towards other males; moreover he chases away both B and A several times. Now a rather long time elapses during which I cannot understand what goes on. I only noticed that the male alighted once on and copulated with B, once with A, next again with female B. After much flying, fighting with other males, etc. the male alights, quite stiff, near female B, runs away from her, skips, I believe, once, flies about and alights farther back on the meadow. But he again starts flying and this goes on for a long time, without the females showing much of interest. Female A is once sitting in another depression than the first time and once chasing away some animal from there. It seems to have the meaning of a nest.

18.00 to 19.00 o'clock. Male and two females present. Male copulates with (female) B, runs away, sits down, perhaps skips a little, chases another male, starts rolling, then go es asleep for the night. Female B sits at his right.

April 17th, 6.45-9.30. The male copulates with female A, then flies to the middle of the meadow, followed by A. She seeks her yesterday's nesting place, sits down for a moment, pecks a little, etc. After some courtship flying, fighting, etc. the male returns, alights on A, copulates, flies away and starts feeding. Female A returns to the nest, sits down, arises, pecks about her, etc. Female B is walking in her neighbourhood. After some, time the male flies to female B, copulates, goes on feeding again. During this feeding the male starts rolling, for a moment; all feathers seem to be erected, the bird looks as if blown up. Then he flies to the back of the meadow walks along A's nest, looks at it and walks away. He then flies to A, copulates, flies away from her, goes on feeding again. All at once A flies to the male, dashes down on him, chases him away (did he come too near the nest?). Now female B comes flying straight towards them. I believe she intended to chase away A. But A alights and B then also, whereas the male copulates with B and begins skipping. A again walks along the nest. After some feeding the male starts rolling not far from B, who finally approaches. But before she has reached him, he flies away, to fight with another male. He then returns, begins rolling in B's neighbourhood again, then goes on feeding. This is followed by some courtship flying, whereupon the male, alights near B and runs away from her (to start rolling?). But female A comes flying from the back part and alights in their neighbourhood, so that the male flies up, alights near her, head high, crest erected, and runs away.

B now flies up, alights in their neighbourhood and is then going to fly to A. But the male interferes. He chases away A (perhaps she wanted to chase B) and remains in her neighbourhood; he then begins rolling and A runs up to him and rolls with him. Now the male first tries to chase away another male, then returns to A, who went on rolling; he again rolls with her. Now B comes flying up, so that the male chases her away; he then returns to A. All at once the male flies to female B, who begins rolling; he rolls with her. He flies to the back, returns, alights on B, copulates, runs away from her, goes on feeding. After walking for a long time he begins rolling again. Female B, feeding comes into A's neighbourhood. The male comes flying from the back, copulates with A (but leaves off very soon), then flies 
straight to B, alights on her, copulates, flies somewhat farther and alights. A moment later he again walks near female A and B. But he again returns to feed in front of me. After some time female B walks up to him. Meanwhile the male flies to the back to fight with another male there. He then walks straight down to the nest, looks at it and returns! I now walk there and find an empty nest; and a second one at the place where A was sitting yesterday, when B was curious or attentive.

April 18th, 7.00-9.15. Male and two females present. When the male flies courtship and alights the back part of the meadow, the two females begin to fight, so that the male returns and chases away $\mathrm{A}$, then begins feeding again. A chases $\mathrm{B}$ again, then the male returns again and chases away A. The male shows a good deal of courtship flying. A Corvus corone flies past. A flies up and pursues the bird, the male also comes up. Female A alights, the male after some flying too. A now chases an oystercatcher, whose husband calmly looks on. The male also comes up and hovers above them, but the skirmish has already finished, so that he alights in front of me. After some flying and staying on the back part of the field he flies to B, copulates and begins rolling; first the male alone, then both together. They then go each their own way. After some flying and staying on the back he again flies to B, copulates, settles in front of me and starts feeding. But the females are quarrelling again and the male has to interfere. After some feeding and courtship flying, he flies again to B; he does not copulate, however, has his head high, crest erected, is angry. He runs away from her, but does not come to rolling because another male has to be chased away. Again some fighting, feeding and flying follows, until B comes into the male's neighbourhood, whereupon he begins rolling. They then roll together for some time. They separate, but after some while the male returns to $\mathrm{B}$, copulates and begins rolling with her, until they separate agaon. After some time the male flies to A, copulates and flies away from her. I do not follow him for sometime and find him back not far from A. He returns in front of me and goes on feeding. After some courtship flying he alights in front of $\mathrm{B}$, runs away from her and goes on feeding again.

April 29th, 18.30 19.30. Male flies to female B, copulates, runs away, followed by B. He begins rolling, then they roll together, a very long time. After some flying he flies again to B, copulates, flies away and goes on flying from one place to another, being quite restless all the time, also rolling a long time. This rolling was constantly accompanied by the sawing sound; once I heard the sound during his flying; this was when the flying ended in copulation.

April 30th, 17.50-19.50. Male again very restless. He constantly flies courtship, flies from one place to another, rolls, fights. He once copulates with A, then flies to the front part of the meadow and alights there, flies after some time to B and copulates again. I now follow female A, who comes walking up the meadow from the back, very slowly. All at once I see her looking very attentively; the male approaches. She receives him with her head high; no copulation follows and the male has also his head high when alighting near her. After some time the male is busily rolling with female B. Then follows a long combat with another male. When this has finished, the male copulates with B. The other male, who, not withstanding the very long fighting did not yield, in the meantime is busily engaged in rolling, so long and persistently as, I think, I never saw before. I do not understand why he is so assiduous, until after some time I discover that he has really succeeded in attracting a female, with whom he is busily rolling. I follow this female until dark and believe she is A, which, moreover, is the only possibility. But I get no certainty. Female B remains the whole evening in front of me. My male does no longer try to chase away the other male. If this long combat between the 
two males did really concern female A, it is interesting to note that the latter during and after the fighting of the two males constantly called "Kee-weet".

May 4th, 18.30. There is a nest with two eggs, on which twice a male sits down for a few moments. I suppose that the nest belongs to female B. Female A not seen. There is another male with a very dark female.

May 6th. The eggs have been taken. Male and female B present. Also the other male and the dark female. Female A not seen.

May 9th. The other male with the dark female present. They have a nest with three eggs; the male broods twice. My male and the females A and B not seen.

17.45. Female B flies away on my arrival, but returns at once, sitting down with such a haste that I cannot doubt but she must lay an egg! Indeed, I later find a nest with one egg, the nest consisting of flowers and flowerstems of Plantago. Now the male, then the female visits the nest, the male also sits down on the egg once. The male several times visits a neighbouring field, whereas the female (B) constantly remains on her meadow. All at once I see a quarrelling (chasing) of two lapwings followed by a third one. They prove to be the females $\mathrm{A}$ and $\mathrm{B}$, followed by the male. When the quarrel is over he copulates with B. A comes up to $\mathrm{B}$ again, to chase her away; she is chased by the male, however. When after a moment he has disappeared. A again chases B away without the male interfering now.

May 11th, 18.45. One of the Lapwings flies away from the nest on my approach. At 7 o'clock the male comes back and sits down on the nest, which now contains two eggs and, I should think, more Plantago flowers. After a short time he leaves the nest and flies to the back, where I find female A and not far from her B. A is very attentive; she keeps her head high and her crest erected. All at once she flies away, now somewhat higher, then somewhat lower, wildly and fast, till rather far above the polder, then returning and alighting rather far back. During this flight she seemed to throw herself now on one side, then on the other, the whole looked very much like a demonstration, perhaps performed under the stimulation of sexual desire. Anyhow, it was very strange. The male and female B meanwhile remain in the meadow.

May 13th, 18.30. On my arrival female B walks away from her nest. She soon returns. Somewhat more back is A. She flies at once away and seems to intend alighting on the field, beside me, which is made impossible by a male. She then alights in another meadow farther away, returns after a short time and tries again to alight on the field, but is again chased by a male. Finally she succeeds in coming down, however. The male must be ours, for there is no other male present. After some feeding A flies in my direction, but again the male dashes down on her. And now I discover that not far from me a third female is walking, which has probably been the aim of A. I shall call her C. After I have discovered her, female A tries several times more to chase her away, each time hindered there in by the male, who pursues her wildly. Once, however, I believe the male chased $\mathrm{C}$ and I believe this followed an attempt of $\mathrm{C}$ to chase away A. The male flies courtship many times and it is very striking that he flies chiefly around $\mathrm{C}$. Not once did he fly around female B or even in her neighbourhood, though he did alight some few times near A. Once or twice the male alights stiffly near $\mathrm{C}$ and then starts rolling. That I am dealing with my male follows from the fact that he is the only male present, from his behaviour towards $\mathrm{A}$ and from the fact that he often alights right in front of 
me. He rolls very much and once very long at a time, quite distinctly with the intention to attract $\mathrm{C}$; when rolling, he constantly looks at her, finally rises from his depression, but seeing that $\mathrm{C}$ just is coming up to him, he continues rolling: $\mathrm{C}$ finally approaches; but $\mathrm{A}$ too, and I think that is the reason why $\mathrm{C}$ does not roll with the male, but walks away. A and $\mathrm{C}$ then come in each other's neighbourhood again and A then chases her very perseveringly though the male each time tries to interfere.

The male and the dark female of the nest with three eggs are present in the neighbouring field, a third male with a female resembling B, seen several days before, inhabit a potato field somewhat farther away. Female B is on the nest.

May 14th, 19.00. On my approach one bird leaves the nest. The male is also present. After some time he flies to the nest, but when he has nearly reached it, he begins flying courtship and I understand from his flying that there is a female too. Both females, A and C, are indeed present. A flies to another meadow. $\mathrm{C}$ dashes on behind her, followed wildly by the male. After some fighting A alights on a nearby field, $\mathrm{C}$ on the meadow, the male on the meadow in front of me, not far from B, who is brooding. A calls several times "kweet", just like yesterday. Somewhat later the male begins flying courtship in the neighbourhood of $\mathrm{C}$. When I rise for a moment, all birds change their position but the male after some flying soon rolls again and indeed for a very long time. As a consequence $C$ approaches the ditch. She calls anxiously: 'Kreet" when she flies over it and alights not far from the male. She does not go up to him, however (fear for A?), though he perseveres very long. He then starts flying courtship for a long time.

May 16th, 8.00 to 11.00 . Female B leaves the nest on my approach, but soon returns. The male stands on a meadow rather far away, together with a female, certainly $\mathrm{C}$. This female flies still farther away and this is certainly the reason why the male is busily flying his courtship so far away, and only now and then comes into my neighbourhood. I believe I saw him pair with $\mathrm{C}$ once; it is very striking, that he shows his courtship flight especially around her. I change my place to follow the male better; B then leaves the nest.

After some time the male pairs with a female, which, I think, is female C (at least not A). She disappears along the ditch and I do not see her for a long time. About a quarter of an hour later the male dashes down on something near the ditch. A female lapwing flies away before him and alights in the meadow. She then walks and flies to the nest and proves to be B. I think the male dashed down on her because she was not on the nest. It is interesting that even now this female, though she probably completed her clutch 3 days ago (May 13th), still copulates.

After some short courtship flights the male feeds a long time in the meadow in front of me. But all at once he flies away and alights close by the nest. Another bird, I believe a female, flies away from that neighbourhood. The male goes to the nest and sits down. I think he has seen the female leave the nest and therefore visits the latter. Some quarter of an hour later he leaves the nest, flies courtship for a while, alights and somewhat later walks to the nest again to sit down. A female, I believe A, approaches and sits down in the tulips in front of me. Now a Carrion Crow, Corvus corone, flies over, harassed by some Lapwings. The male flies right away from the nest. The female from the tulips, probably A, does the same, continually calling "Keewt" in the meantime. When corone has disappeared, the male copulates with a female, I do not know which, while another female sits close by. Shortly after the male sits on 
the nest again, but for a short time only. After some courtship flights he copulates with C, runs away and somewhat later sits on the nest again. After some time he flies again and female $\mathrm{B}$ goes to the nest and sits down, whereas $\mathrm{C}$ remains where she copulated. I change my place again and walk back to my former one. Female $\mathrm{B}$ leaves the nest, $\mathrm{C}$ is still sitting in the meadow. A is also present. The male alights in front of me, but somewhat later flies away. When he comes back, he alights "stiffly" near C, starts feeding, thereby chasing a Redshank, Tringa totanus. He finally flies away again and chases another Lapwing. He is followed by C, who calls "Keewt" and alights in a meadow nearby. After some moments the male flies to the nest and B flies away, calling "Keewt". Once more the male flies around, then he returns and sits down.

March 27th, 7.30. Two female Lapwings are feeding in the meadow in front of me. One has much white in her throat; I shall call her female X. The other has only a small white spot in the black of the throat; I shall call her Y. More to the right are one or two others. To female X belongs a male whose white superciliary stripes nearly meet above the base of the bill. Another male, who seems to belong to female $\mathrm{Y}$, has these stripes shorter. Male X is very busy; he chases other males, once another female. I now think this bird may have been a one year old male. He rolls all the time, etc. After some time male X, at the limit of his territory, is rolling and thus endeavouring to allure female $\mathrm{Y}$, in which he succeeds. But now female $\mathrm{X}$ approaches wildly and tries to chase $\mathrm{Y}$. Whereupon the male becomes angry and chases female $\mathrm{X}$ away (Male $\mathrm{Y}$ is not mentioned again in my notes).

May 28th, 15.30. There are six birds in the meadow. First of all male and female X. Then a female resembling female $X$. To her seems to belong a male with some white in the black of the breast. This male seems also to be interested in another female, probably female $\mathrm{Y}$ of yesterday. To the latter female, however, a third male seems to belong.

March 29th, 15.00-17.00. Male and female X present. Now and then other birds visit the meadow.

March 31st, 15.30-17.30. Male X comes on; another male, already present, is not chased away. After some time male X flies to another meadow, where another male endeavours to chase him away, but he becomes furious then, chases away this other male himself now, and returns to his former meadow. After some moments female $\mathrm{X}$ comes. The male begins his courtship flight and chases away another male. At 16.20 female Y alights not far from female $X$. Hereupon the male alights stiffly near $Y$, then runs to $X$, to chase her far through the air. She cries "Kee-weet", whereas female Y sits down as though on a nest, and the male begins flying his courtship flight. He continues this for six minutes without interruption, then alights for a moment, but every now and then begins flying again, chasing away all other males. At 16.47 female $\mathrm{X}$ approaches, high through the air, calling all the while. She pounces down on female $\mathrm{Y}$ and chases her away, whereupon the male chases away female X. Somewhat later there is much flying of migrant lapwings During this female $\mathrm{X}$ returns again, crying all the while. She alights. The male alights beside her, erect. She first crouches down, then runs away before him and flies up. When he remains on the spot, she alights again. He begins flying his courtship-flight around her and then rolling near her. When I leave the three are quiet. 
April 2nd, 15.30-16.15. Male and both females present.

April 3rd, 7.30- 11.15. Male present. After some time female X returns and alights in the meadow, accompanied by the male, who flew up to encounter her. He alights stiffly, then flies to the tulips nearby. Female Y returns, alights near the male. Female X flies up to her, but the male does the same with the result that all three alight in each others neighbourhood. The male begins flying his love flight, while both females, a short distance apart, follow his movements with their eyes, turning and stretching their neck. When the male is fighting with a rival, they follow him attentively too. He alights in three different places and each time female $Y$ runs at once in his direction. A flock of starlings rises from the meadow and their example is followed by the male and both females. Female $\mathrm{X}$ uses this opportunity to chase $\mathrm{Y}$ on the wing, so that the male now has to chase female X. Nevertheless she alights near him in the meadow. Then a third female makes her appearance. She has a narrow white throat-patch and we will call her female Z. The male alights stiffly near her and follows her when she runs away; she flies up and alights again, then remains. He now begins rolling She comes rapidly up to him and sits down near him. Whereupon the male flies up to female $X$ to chase the latter away. She alights in the tulips. He continues rolling, with $\mathrm{Z}$. When he starts flying, fighting etc. female $X$ in the tulips now and then cries "Kee-weet". After some time the male alights in the tulips in the neighbourhood of X, then on the meadow not far from $\mathrm{Z}$.

Thereupon the male flies again to female $X$ and chases her away again, high through the air. She returns every time, however, each time endeavouring to chase away female $\mathrm{Z}$ while alighting. Male and female while doing so flight with rapidity like lightning. But $X$ does not succeed in chasing away $\mathrm{Z}$. At last $\mathrm{X}$ alights in the tulips, notwithstanding the male constantly tried to prevent it. The male flies to the meadow. After some time female $Y$ returns and chases $Z$ away. Of course the male interferes, but now an incredibly furious combat follows. Female Y positively refuses to be chased by the male, who can neither succeed in getting her on the wing. She almost upsets him in her endeavours to reach female Z, who is constantly protected by the male as he tries to keep himself between the two females.

Every moment female Y runs up to Z; but the latter does not make way either. Finally Y begins rolling! Every time she does so, however; female $\mathrm{Z}$ becomes furious and tries to chase away $Y$. The result is that the combat is renewed again and again. Sometimes $Z$ is the assaulter, another time $\mathrm{Y}$. The male seems desperate. He flies from one to the other and back again, is angry with both, but cannot reach his end, as the females scarcely mind him. When he chases Y, she crouches down in a tuft of grass, each time the same one, and refuses to leave it, though he pecks her several times. As soon as he has left, she continues rolling!

After some time there is a state of quietness, of armed peace. The male rolls again (thus seeking an outlet for his emotion), whereupon female Y comes up to him, But after some moments he chases her away, she flying or running a little way in front of him. Some boys appear on the scene now. Female X flies away, high and far, always crying, returning, however, and alighting not far from the two other females. Some quarter of an hour later the male and female Y, after having been absent, alight on the meadow. When he begins rolling, Y runs up to him and continues it, whereupon they walk away again.

It is interesting to note that female $\mathrm{X}$, in the tulips, was crying her "complaining" Kee-weet" on several occasions: when the male rolled and female $\mathrm{Y}$ went up to him, every time when he was wildly fighting, or when he was chasing, other males apparently every time when he came flying over her and further, I believe, when the two females, Y and Z, fought so 
furiously. Finally, when female X flew away herself. Her excitedness made it possible to note very accurately what interested or even excited her and she showed quite plainly how all the doings of the male especially interested her very much.

April 10th, 8.00- to 10.30. Male has removed his territory a little. He pairs and rolls once with female X.

14.30-16.00. Male copulates with female Y. Somewhat later female $X$ appears, alighting in the tulips. The male starts flying courtship around her, then begins rolling whereupon she approaches, and both roll together. Meanwhile female $\mathrm{Y}$ has approached through the meadow till quite near the ditch, so that the male all at once flies up to her to chase her away. She flies away indeed, but at the same time tries to chase away female $X$ and alights near the latter, after her endeavours have been in vain. The male alights between them. Thereupon they start walking or feeding and female $\mathrm{X}$ rolls some time with the male, who is very excited and flies courtship, rolls or fights continually this afternoon.

April 18th, 8.30-10.15. Male present, rolls once with female X. Female X herself rolls once on her own behalf, whereupon (he male flies up to her and alights stiffly beside her. Another female, as far as I can conclude from her plumage certainly female Y, copulates with another male.

April 20th, afternoon. Female Y copulates twice with the other male of April 18th, female X twice with male $\mathrm{X}$. The male alights once stiffly near female $\mathrm{Y}$, then running away from her; whereupon the other male chases him quite perseveringly. Another time the male alights near a third, very dark female I did not see before; I believe he was chased away by another male here too. Male and female X, as well as female $\mathrm{Y}$ and her male are rolling.

May 8th, 8.30-10.00. Shortly after my arrival the male copulates with a female apparently Y, runs away and rolls; after some courtship flying he alights near $\mathrm{X}$ and chases her away. This is repeated twice more. He then starts a long, and busy courtship flying and rolling, and alights now in the meadow, then in the potato field nearby. In the latter is female $\mathrm{Y}$, while $\mathrm{X}$ is in the meadow. He copulates with female $Y$, runs away and starts rolling again, again followed by courtship flying. He is quite excited. Meanwhile X seems to have approached $\mathrm{Y}$ so that she is chased away there by the male. He starts courtship flying again, alights near $Y$, rolls again. After some time this is repeated once more, again followed by courtship flying. Then he starts rolling again and female $\mathrm{Y}$ runs up to him and rolls with him. But all at once the male flies to female $\mathrm{X}$ and pecks her apparently with great violence. She is sitting deep, so that I cannot see her; the male, however, is positively hacking at her, right down. At last she appears chased by the male, who drives her away before him, each time a short distance. The male then flies to the meadow, returns, copulates with $\mathrm{Y}$ and flies away again. When I leave, all three are resting quietly in the meadow.

May 15th, 8.30. Male, female X and another female, a dark one present. I call the latter Z'. Both females appear to have a nest, female $X$ has 4, Z' 3 eggs. Shortly after my arrival the male walks to the nest of $X$ and sits down. When another male flies above the females, he flies straight from the nest to chase the other away. He returns and continues brooding. A moment later he flies away and now female $X$ walks up to the nest, takes something in her beak, flies with it to the ditch and returns, walking the last stretch. At the same time Z' approaches her nest and sits down too. After a quarter of an hour the male walks to the latter 
nest and sits down on it; Z' appears to have walked away. He remains brooding for more than half an hour, when I walk up to him, to inspect the clutch.

May 22nd, 8.30. Both clutches have been taken. The male copulates with Z'.

May 29th, 9.30-12.30. One of the most interesting days! There is again another female, still darker than the dark one, who is also present. This new female, which I shall call Z”, walks to a nest and begins brooding. But she leaves her nest very often and each time the male continues breeding then. Several times he flies straight away from the nest to chase away a Herring Gull; on my approach he walks or runs away, however. After he had again sat on the nest for a very long-time, the new female, Z", returns once more and now the male starts courtship flying above a neighbouring field. He flies so long and continually, thus getting rid of all the energy piled up during brooding, that it is not difficult to understand there must be a female there. And indeed! His play concerns Z' of May 15th. Of course I look after female X, I find her, but she has finally left her male and copulates with an other (seen once).

Evening. The new female Z" walking near or sitting on her nest. The male is also present and he is again much interested in Z'. There are, however, three other males, who apparently would like to pay her their court. Especially one of them is busily rolling. Each moment a combat develops between three of the four males. The fight is quite furious and concerns female Z' only I cannot see the female quite well because she is sitting in the bulbs, but the males seem to dash down on her, apparently to chase her away (get her on the wing) and she crouches down then and cries continuously 'tee-tee-tee-tee', a soft, somewhat piping sound. The male in question alights and is harassed by another then, who tries to chase him away. Each time the third male at once indulges in this combat too. Sometimes our male, the fourth one, joins the battle, but he is not at all active and seems hardly to defend himself. The result of all this is that each moment furious ground battles take place, continuously accompanied by heavy wingstrokes, which can be heard at a distance. I remain till dark, when the birds are still fighting. It is interesting to see how this furious battle, which seems to take no end, concerns a female and not in the first place territory. Another interesting point was that female Z" on her nest was continually softly crying each time when the males were fighting, also when her own male was not among the fighters. Thus the heavy fights formed a strong emotion not only for me, but also for her.

June 5th, 9.30.The clutch of Z" has been taken. Male and female both present. Female Z', for which there was such a furious fight on May 29th, is also present; an overflying male harasses her for a moment, another does the same, she crouches down both times, calling "eeee-ee-ee".

July 3rd. A male, female Z" and another female are very uneasy.

March 27th, 6 00. Waal en Burg, Texel. -Male in front of me present; other males to his left and right. Behind them a fourth one is busily rolling, courtship flying, etc. This male has a female, who is attracted by his rolling. Nevertheless somewhat later the male runs to another female. Though none of the three other males has a female, this male has attracted two. As he is quite active, activity is certainly the reason of his success. 
This unfinished manuscript by Jan Verweij has been made available through Wader Study 124(1) at http://www.waderstudygroup.org/article/9294

May 8th, evening, near Den Helder. Two female lapwings are brooding in front of me, some 40 metres apart. After a long time one of them leaves the nest and begins feeding. Somewhat later a male comes up and sits down on the nest. After some 20 minutes the other female flies from the nest when I rise. Now the male from the first nest leaves his nest, follows the female of the other nest in her flight and copulates with her after she has alit. He feeds again for some time, flies up and then runs to the first nest and continues brooding. The female of the other nest now returns to it and sits down again. 


\section{Summary of some principal data.}

Some of the principal data of the observations of 1926 and 1927 may be shortly summarised here.

1926. On 13,14,15,16,17,18 and 29 April the male lives together with females A and B. On April 30 th another male attracts female A, the male keeps female B only.

4 May. Female B has probably two eggs.

6 May. Clutch has been taken.

9 May. Female A with male. Female B lays an egg.

11 May. Females A and B present; B has two eggs.

13 May. Male lives together with females $A$ and $B$ and tries to win female $C$.

14 and 16 May. Male lives together with females A, B, and C.

1927. On 27 and 31 March and 2 April male lives with females X and Y.

3 April. Male with females $\mathrm{X}$ and Y, moreover flirting with Z.

10 April. Male with females $\mathrm{X}$ and $\mathrm{Y}$,

18 and 20 April. Male with female X. Another male lives and copulates with Y.

8 May. Male lives with females $\mathrm{X}$ and $\mathrm{Y}$ again.

15 May. Male with female $X$ and a new female, Z'. Female 3 has 4, Z' 3 eggs.

22 May. Male copulates with Z'.

29 May. Male with female Z' and another female, Z", brooding her eggs. Another male lives with female X.

5 June. Male with females Z' and Z"! Clutch Z" has been taken.

\section{Discussion.}

No one can deny that the lapwing represents a fine instance of a monogamous species. As a rule the male, after having established a territory, 'marries' one single female. The latter shows the same jealousy towards other females as the male towards his rivals. When the clutch is complete the male may brood the eggs when the female leaves them. Both male and female protect their nest and the young from intruders. There is nothing in the behaviour of pairs living an isolated life in the dunes or in thinly inhabited polders that would mark them as polygamous. And yet, how strongly developed are the lapwing's polygamous inclinations. Give the male a chance to behave polygamously and he will do so. Selous and Huxley have described flirtations in the Great Crested grebe, Portielje in the Herringgull, Holstein (1927) and I (Verwey, 1930) have described brooding female grey herons being assaulted by eager males. But we may certainly be sure that the lapwing forms an exception among monogamous birds in so far as his polygamous inclinations are concerned.

Notwithstanding it being of rather common occurrence the lapwing's polygamy has only quite recently attracted the attention it deserves. Brock did not suspect its existence, though it follows from page 301 of his paper that he did see a male mated with two females without knowing this himself, see below. Raven describes in his In praise of Birds (I only saw the Dutch translation) how he found near Knocke in Belgium two nests, about 50 metres apart, apparently belonging to one and the same male, as there was no other one in the neighbourhood. A similar case is described by Jorritsma (1931), and the lapwings polygamy was also mentioned in an article in the Dutch newspapers De Telegraaf and De Courant in 
April or May, 1932. Part of the diary of my own observations was published in 1927 and in it the behaviour of a male paired with two females is described. These observations were known to Rinkel and Brunhilde Laven when they published theirs. Rinkel states that the male by scraping invites nearly every female which alights on his territory, also when he already possesses a female. And as the females according to Rinkel show little rivalry, bigamy or even trigamy according to him occurs very often. I should fear that Rinkel, somewhat influenced by my own paper, now considers the occurrence of polygamy a little too common, but he also states that the majority of the males he studied had more than one female and in 1936 there were in his area of study 3 males with 7 nests, "from which it is apparent that one of the males must have possessed at least 3 females. Brunhilde Laven mentions two cases of polygamy she observed in 1938, one in 1939. Both cases observed in 1938 concerned a male with two females, whereas the male observed in 1939 was seen copulating with 3 females within 2 days. Brunhilde Laven cites her full observations on these birds, which I shall mention below in connection with my own conclusions. I should finally add I have little doubt that many cases of polygamy in the lapwing have been overlooked. Nicholson, in his report on the lapwing habitat inquiry, 1937, states on p. 210: "One other point examined by Mr. Thomas was the distance between nests, the shortest noted being 19 yards, with 10 cases of 30 yards or less, on the Lancs .- Yorks border two pairs were noted breeding within 10 yards (C. Oakes)".

In my mind, we may be sure such cases represent as many instances of polygamy. Compare also the note of Paget-Tomlinson (1939).

The study of polygamy in a monogamous species is especially interesting, it seems to me, for two reason.

First we have the question why and how one male may succeed in winning two or even three females. Secondly, there is the question how the male behaves towards each of his females and especially how the females behave mutually and towards the male.

The question how one male can succeed in winning two or even three females involves several points of interest. Are there, in relation to the number of males, too many females? Or are there besides males with two females solitary males? In that case, why does one male get two females, his rival none? Is he more active? Or plays something like attractiveness a role just as in man? This brings us to the much discussed subject of so-called choice.

The question how the male behaves towards his two females and how the females behave towards him and towards each other is no less interesting, for the wish to compare our observations with those concerning another, quite interesting species, man, is constantly brought before us.

Let us therefore treat these points in some detail.

First we have the question why and how one male may succeed in winning two females. Are there more females than males so that some males quite easily get a second female? I do not think so, though it is difficult to get certainty on this point. Statistics of chick mortality in domestic fowl have shown that mortality is greatest among the females, and it has even been assumed that as a general rule in the animal world the higher death rate occurs in the sex with an uneven number of chromosomes, i.e. the female in birds, the male in a number of 
mammals (including man), fishes, insects and crustaceans (Geiser, 1924). From direct observations I am inclined to conclude that in the lapwing, as certainly in the grey heron, there are slightly more males than females, but in the lapwing such a conclusion is dangerous, as the males are much more mobile and active than the females. Brock says that there is reason to believe that the females are numerically somewhat inferior to the males, but he omits stating on what this belief is based. Rinkel, on the contrary, thinks there are more females, but his conviction does not rest on a firm base either. A point, however, which shows that a surplus of females need not be the reason of the male's polygamy is afforded by the fact that there do occur solitary males, living side by side with bigamous ones, and that in the beginning of the breeding season some males have got two females before their neighbours have any.

Such an unmarried male may constantly try to attract a female, scrape when she comes into his neighbourhood, fly courtship and fight, but his endeavours are constantly frustrated by the incessant attentiveness of the neighbouring male. I therefore think that generally speaking, bigamy in lapwings is based first of all on the polygamous inclinations, sexual activity or other particulars of the males in question and not on the greater number of females.

Kluyver (1940, p. 39-42) comes to just the same conclusion for the European wren, in which species polygamous and non-mate birds may occur beside each other.

8 May. 1932, near Den Helder: male number 1 every time tries to approach the female mated with (male) 3 whereupon heavy fights, between both males follow. Several times (male) 1 runs in their direction when male 3 and the female are "nesting" together. Once, I saw how he got wind of the fact that male 3 saw him approaching, and came flying up to him, but still at a large distance. He ran back to his corner of the meadow as fast as he could and, long before the other attacked him, crouched down, to run farther away directly after the attack. Some few times male 1 flies directly up to the female, trying to alight in her neighbourhood. But every time male 3 makes this impossible. It is nice to see how much trouble may be caused to such a mated male to keep his mate for himself. When we admit that some males do get two females and other males none we of course ask if the possibility can be excluded that some males are what we should call in human language more attractive than others. In other words we come to the much discussed chapter of preference of one of the sexes, of so called choice.

It has been stated several times already that true choices, a conscious choosing, cannot well play a role in birds. Portielje (1931), in his paper on the ruff, has stated this in the following way:

"Hat das Erblicken einer Gesamtkonstellation mit vielleicht etwaigen überwerteten Merkmalen, denn als solche wird ein Vogel Weibchen wahrscheinlich sein Männchen vor Augen haben, mit unserem vergleichenden Schönheitsempfinden wirklich schon etwas zu tun? Eher wäre es schon zu verstehen, dass em paarungs-süchtiges Weibchen, für secundärsexuelle charaktere doch gewissermassen empfindlich, sich von einem ihr zur rechten Zeit vor Augen kommenden Mannchen nach kürzerer oder längerer Zeit als vom adäquaten Reizkomplex "bestürzen" und zum Paarungsakt bewegen liesse. Wird doch auch von Vögeln wohl mehr oder weniger gelten müssen, dass - wie em holländischen Sprichwort besagt -'die Liebe eben blind sei"28 (Huxley, 1914, p. 559).

${ }^{28}$ Is the perception of a female bird of the possibly excessive features of the male, comparable to our comparative feeling of beauty? It would be easier to understand that females willing to 
True choice certainly supposes a higher psyche than we have a right to expect in birds. Even Darwin himself, though many after him forgot this, did not believe in it and was of opinion that the hen bird would probably be struck by the general effect of the displaying male only and would probably not admire the spots of his beautiful plumage (Verwey, 1930, p. 28).

This does not mean, however, that the possibility of a distinct preference for certain males from the side of the female, or the reverse, can be excluded. Everyone, who has read Selous' unsurpassed diary notes in his paper on the ruff, will agree with me that such a preference has been shown by him to exist. The attractive force of his 'red" ruff on eager females is, to say the least of it, remarkable. Probably no less than $4-5$, but at least 3 reeves paired with this bird, at least 2 paired with the "blue" one. Selous" observations on the nuptial habits of the blackcock point in the same direction, but are less conclusive. Portielje does not give these facts the necessary attention. Though he states that he has tried to analyse the behaviour of the sexes, "statt es auf theoretischen Gründen prinzipiell einseitig auf Zuchtwahl und Stimmmangel zurückzufüren" ${ }^{29}$, he neglects the distinct preference of the females for a certain male and says only: "Vor allem will es mir schon nicht recht einleuchten, wie ein kopulationsbedürftiges, eben von aufwallendem Trieb "getriebenes" Vogelweibchen sich die Schönheit verschiedener Männchen zuerst mal "besehen" und "vergleichen" sollte, wie es die Theorie der sexuellen Zuchtwahl ja doch annimmt" 30 . Selous, however, summarized his viewpoint quite well (1907, p. 168): "To be more responsive to the charms of some males than of others is to have choice, just as much as we, in such matters, possess it - and such choice must be founded on something". And in his paper on the blackcock (1910, p. 250) Selous remarked: "and as each one elaborately displayed the same points in his plumage before her, we must assume these - that is to say, (the sum total of each bird's, appearance to have been the determinants of her choice". But even Portielje feels that something like preference cannot be wholly neglected. For he supposes "dass ein kopulationsbedürftiges Weibchen wenn es gewiss auch nicht "Schönheiten" vergleichen wird, vielleicht doch während des generellen "Bestürztwerdens" von irgend einem weiss - oder schwarz - oder buntkragigen Männchen in toto sich die auffällende Färbung desselben gewissermassen mit einprägen mag. Mit der von diesem Männchen empfundenen sexuellen Befriedigung könnte sodann die auffällende Färbung seiner sekundar sexuellen Geschlechtscharaktere assoziiert werden. Diese eben sexuellbetonte Assoziation könnte dann späterhin das Verhalten des Weibchen dem kollektiven sichbenehmen der Männchen gegenüber mehr oder weniger bestimmen und es aufs Neue in die Armen des selben Geliebter führen" ${ }^{31}$. This would

pair and sensitive to secondary sexual characters, meeting a man in the right time, after a shorter or longer period, arrive in the same excitement and copulate. Also for birds the Dutch saying may hold: "Love makes blind" (Huxley, 1914, p. 559).

${ }^{29}$ rather than on theoretical grounds in principle one-sided on selection and lack of voice ${ }^{30}$ Above all, it does not seem to me to be quite clear how a female bird, who is "driven" by the impetuous impulse, should first "look" and "compare" the beauty of different males, as the theory of sexual selection accepts.

${ }^{31}$ That a female that wants to copulate, although certainly not comparing the "beauties" may perhaps, during the general "consternation" be attracted by some male with a white or black or variegated colored collar. With the sexual satisfaction perceived from this male, the conspicuous colouring of his secondary sexual characteristics could be associated. This sexually assisted association could then later more or less determine the behaviour of the female towards the males, and lead them again into the arms of the same lover. 
contain, however, that in other birds, where plumage polymorphism fails altogether, such a preference of a female for a certain male bird would not occur. I cannot believe so and have given a very remarkable case of "choosing" by a female grey heron in my former paper (1930. p. 56-66). The more we study birds the more we are impressed by their enormous powers of discrimination in cases where we ourselves forsake. In this connection several recent observations leave no doubt, (Lorenz, 1935; Kortlandt, 1938, 1941 p. 73, see also Verwey, 1930, p. 39-43). The female lapwing identifies her male from many others living in close proximity. Why then could she not see small differences in form or expression of different males? Or, in any case, identify them from their sounds? And if so, why then would such characters not be of the same value to her as the plumage polymorphism of ruffs to the reeve? Portielje has limited his train of thought exclusively to Philomachus and therefore could present the question as though the female bird, "em kopulation bedürftiges, eben von aufwallendem Trieb "getriebenes" Vogelweibchen"32, had no opportunity to detect differences between males and was simply won by the one who came in her neighbourhood the moment she was most eager. As already remarked above I personally do not believe that such a state of affairs holds even in Philomachus. But, moreover, we are not dealing with this species now, but with a bird, in which true pair formation precedes copulation. We see - as is only natural - that the female lapwing easily identifies her male from many others, though we ourselves must look at these males for a long time before we see any differences.

We cannot avoid the conclusion, then, that small differences of sound, plumage, habitus or expression must have some meaning to her.

The question remains, however, whether preference can be based on something else than powers of discrimination. I remarked already that my impression is that bigamy may be based, among other things, on the sexual activity of the males in question. For how does a certain male succeed in winning a second or even a third wife? They are won in just the same way as the first one: especially by song flying around her and scraping, further by preventing other males from coming into her neighbourhood, in short by all that kind of activity which may succeed in raising sexual activity in the female above the necessary level. I do suppose that this great activity plays a role of some importance in the formation of numbers of three, because some of the bigamous males I studied certainly did belong to the most active ones. Brock says the same: Other things equal, the male which is most active in courtship is probably most likely to secure a mate'. He gives no evidence for this opinion, however. Activity can be important, because, notwithstanding the fact that the activity of a certain bird may be much greater one day than the other, there remains a great difference between the activity of different males. This does not only hold for the lapwing, but probably for any species studied. Kortlandt (1938, p.23) mentions the cormorant in this respect, Lack (1939, p. $296)$ the blackcock and robin, Kluyver (1940, p 37-42) the European wren.

That (sexual) activity is of importance in connection with the formation of numbers of three (and of pairs generally) is also shown by the observations of Dewar (1920), who states that the coloured peahens in the Zoological Garden of Lahore preferred the white males, because they strutted more than the coloured ones; and by Kortlandt's observations, that a male Cormorant with very great sexual activity, though possessing few white feathers (which are important in connection with display), was seen to copulate with three or more females and, besides, to attract a great number of others. Further, also by the observations of Kluyver

${ }^{32}$ A "birdworm," driven by the need for copulation, "driven" by the impetuous impulse 
(1940, p 41-42), who comes to the conclusion that those males of the European wren who build the greatest numbers of nests get most easily a mate and that those of his males who remained unmated all built few nests. Kluyver adds, however, that also some of the males with many nests remained monogamous and he is further of opinion that also the quality of the male nest is of great influence in the choice of the female.

Though, I do, therefore believe that activity of the male plays a role of some and perhaps even of much importance in the formation of numbers of three in the lapwing, I do not think that sexual activity is the only agent. For, to ascribe the success of male X of 1927 to his activity alone seems to me a bad representation of the actual facts. He has a strongly attractive force on all females coming into his neighbourhood (first $X$ and $Y$, later $Z$, afterwards Z' and Z'), who surrender themselves so readily that I think some other factor must come in here, something like attractiveness loose from activity. Just the same holds, in my eyes, for Selous' "red" ruff. It seems not possible that small plumage differences (differences in the iridescence of the green, in the length of the crest feathers, and the like) are of more influence than we should be inclined to believe. Since I wrote my paper on the grey heron (1930, p. 28-31) a great many new observations have added considerable to our knowledge of the enormous importance of secondary sexual characters in display and again and in we have seen "wie die Zusammenwirkung von Bewegung und Schmuck hier zum Vorteil der Art werden"33 (Verwey, 1930, p. 31). I may also cite in this connection the experiments with Melopsittacus of Miss Cinat-Thomson (1926) and later and the observations on normally displaying blackcock males with rather poor tails of Lack (1939, p. 293). The observations of Kortlandt (1938, p. 23) on cormorants and those of Kluyver et al. 1940, p. 41) on a wren with abnormal song may point in the same direction. I should still mention the possibility that it is not the bird, but the favourable situation or size of the territory which attracts the females.

This possibility, suggested by Howard (Kluyver et al. 1940, p. 33) is in itself certainly not strange. I think, however, that in the case of the females $\mathrm{X}, \mathrm{Y}$ and $\mathrm{Z}$ it can be excluded, because the females themselves made the male constantly shift his territory. It is therefore illogical to assume that this possibility would play a role of importance in other cases. Kluyver et al., (1940, p. 41) do not think it is of value in the wren either.

We have now come to the question how the male behaves towards his two females and how the females behave towards him and towards each other. This is a very interesting subject indeed and a comparison with human behaviour reveals some points of great interest.

I will deal with the male behaviour first.

When a married human being flirts with a second member of the opposite sex this will by preference occur during the absence of the true husband and, so far as I have been able to make this out, this holds also for those people in which polygamy is lawfully permitted. The prime ground for this lies, as far as I can see, in the fact that Homo sapiens, certainly in all his races, is a typically monogamous species and therefore possessed the instinct of all such species: jealousy, failing in polygamous ones. This causes the female to react as soon as a second female enters the scene and it is the "fear" for this jealousy and anger of the female, which influences the male behaviour.

${ }^{33}$ how the combination of movement and ornaments will here be of advantage to the species 
The married male lapwing tries to win a second a female not only during the absence, but as well during the presence of the first one. So we may ask first of all: does female jealousy not influence the male behaviour here?

Let us therefore see what happens when a second female appears on the scene. When a married male lapwing tries to attract a neighbour female by "nesting" and courtship flying we superficially do not see much difference in the behaviour of his wife. As a rule she goes on feeding, walking, feather preening, etc. When, however, sooner or later the male leaves the ground for some time we shall see in many cases that the true female walks in the direction of the second one and begins to chase the latter (e.g. diary notes: April 15, 1926). When the new female does not leave, a furious combat may result on his return always ending in anger of the male, who does not stop chasing the chasing female till peace has returned (diary note: May 13, 1926). The chasing of the second female by the first is the immediate result of the jealousy of the latter. It is never directed towards the male, but always solely towards the rival. Now, though mostly the true female awaits the absence of the male, she will in some cases try and chase her rival during the male's presence and more intimate knowledge of the birds teaches us, that, generally speaking, the appearance of a second female awakes the thorough interest of the first, even in cases where at first sight the latter does not seem to take any notice of the newcomer. She walks constantly in such a way as to keep sight of the latter and when the rival is hidden from sight by some object she may be seen to crane her neck not to lose sight of the other. It goes without saying that no one observes this behaviour of the female sooner than her own male. Though he may be busily engaged in "nesting" to attract the new female, we may on rare occasions see how he flies at once to his own female to chase her away. The reason is that the latter has shown interest in her rival may or may not have walked in the direction of the latter and therefore is considered a danger by the male now, who wishes to get rid of it (e.g. diary notes: 14 April, 1926, 31 March, 1927). I have even seen the male chase his own female in cases, when it seemed excluded that the female had shown interest in the scene (diary notes: 3 April and 8 May 1927). But on the latter date the male chased $\mathrm{X}$ several times probably because he did not consider her any longer his wife. This may show that in such cases the male, feeling the simple presence of the female as a danger, behaves as such. But it may also be that we should not too soon conclude from the outward appearance of a bird on what is going on in it. I have stated twice already that Brock must have observed a male lapwing with two wives, though he did not know this himself. The passage in question (page 301 of his paper) runs as follows. "Females occasionally evince considerable jealousy of each other, indicated in a manner similar to the males. On such occasions the two rival birds, settled near each other, sway their tails up and down rhythmically, and scrape slightly, plucking a little at straws. Ultimately one may rush at the other, and a short bout of brisk sparring ensues. Several times I have been considerably interested to observe such encounters between two females ended by a male bird rushing up and separating the combatants, and, not content with terminating the strife, he attacks one of the females, driving it to some distance, a mode of behaviour only witnessed under similar circumstances. On one occasion a male which was courting a female bird, suddenly desisted to attack and pursue a second female at a little distance."

As females of neighbouring pairs do not react on each other by nesting" and do not chase each other, whereas the scene described by Brock wholly agrees with the scenes described by myself for numbers of three, there is no doubt that the males in question have lived in bigamy and been chasing one of their wives. 
The only particulars Rinkel gives concerning these details are contained in his remark that, whereas the male tolerates no birds of the same sex within his territory, the female shows little rivalry. The latter is restricted to the nearest scrape and its immediate neighbourhood. Chasing between females as a rule does not occur, because the male interferes as soon as he observes it. He may then even chase a female with which he has long been mated.

Brunhilde Laven (p. 29) gives a good description of the behaviour of the only female of a couple of three on which she gives such details. "Als nun das Männchen bald darauf mit einem anderen Weibchen kopulierte und scheinnistete, war es überaus auffällig, wie erregt das Weibchen A an seinem Nest herumlief und wie viel es flog. Während sonst ein Kiebitz bei der Nahrungssuche nur selten hastige Bewegungen macht, lief das Weibchen A sehr schnell von einer Stelle zu andern. Sein Hals war mehr als üblich gereckt, die Tolle stand oft steil in die Höhe. Einmal hatte es gar den Anschein, als wolle Weibchen A sein Männchen von den "Abenteuern" mit einem anderen Weibcghen zurückhalten, als es nämlich dem Männchen zur Düne nachflog. Die vermenschlichende Deutung der "Eifersucht" liegt hier für den Beobachter des Weibchen überaus nahe" 34 .

All this means that the male, when trying to win a second female in the presence of the first, chases his own wife as soon as he observes that the latter forms an obstacle to his doings. One gets the impression, therefore, that there is much agreement between man and lapwing in this connection. I am not sure that this also holds for the following.

The male's wife is chased, because she chases her rivals the new wife. When the rival has been more or less accepted by the male, however, she need not remain the chased one, but may begin to chase the true wife herself. In that case the male invariably will immediately chase her instead of his first wife (compare diary notes: April 17 and May 13 and 14, also females $\mathrm{X}$ andY on 3 and 10 April, 1927) and this brings us to cases where the females fight wildly together, when the male chases now the one, then the other, and finally does not know what to begin. He may then become so excited that he will chase away the female which is attracted by his scraping: see April 3, 1927. The question is that the male cannot tolerate that one of the females chases the other. Even in the case of the male of 1926 with his three females $\mathrm{A}, \mathrm{B}$, and $\mathrm{C}$, he does not become partial, but always chases the one who chases another, though the chased one may answer his sexual desire more than the two others (female C on May 13-16, 1926). This is, in my mind, a very interesting point indeed and will certainly not hold for all cases of human polygamy. The only other instance I know of such behaviour in animals is that of a dog (a retriever), described by Miss R. Holloway (1915). He was nicknamed the Policeman, because he would always separate two other dogs who were fighting or those which looked as if they might. He would always tackle the aggressor and not leave him until the dog attacked was safely away. I am further well acquainted with a child, which has the habit of "separating" her parents when they show light discussion-

\footnotetext{
${ }^{34}$ When the male soon thereafter copulated with another female, it was very striking how excited the female A ran around her nest and how much she flew. While a food-searching lapwing rarely makes hasty movements, female A ran very quickly from one place to another. Her neck was stretched more than usual, the crest often rose steeply. On one occasion, it seemed as if female A would keep her male from the "adventures" with a different female, when she went after the male to the dune. For the observer of this female a humanizing interpretation of "jealousy" is here imaginable.
} 
quarrels, thereby always "attacking" the parent who attacked first. I suppose that this behaviour must occur oftener among children and have a more general foundation.

In agreement with all this, the male lapwing, who has more than one wife, is a very true husband to both. Not only does he copulate with both [April 14, 1926, male copulates twice with female A, twice with B, April 15 four times with A, three times with B, April 16 twice with A, twice with B, April 17 three to four times with A, four times with B, April 18 three times with $\mathrm{A}$, once with $\mathrm{B}$, during the hours of observation], but also will he cover the eggs of both when the females leave them (15 May, 1927), defend both nests, etc. It is quite remarkable to see his interest in the still empty nest of one female when he has a second wife (diary notes: 17 April, 1926). He may also brood the eggs of one wife and copulate with the second (16 May 1926, 8 May 1932). Rinkel draws attention to this point by observing "that the male does not find himself in a certain phase", as he may be seen to scrape with one female and a moment later relieves the other at the nest.

These notes on the male behaviour are not complete before we have dealt with his reaction on a neighbour's endeavours to approach his wife (or rather one of his wives) or the reverse. The male may be furious then and show an endless perseverance in chasing the other male. Heavy combats between males may thus be the result of the neighbour's trials. The quite violent combat described under May 29th, 1927, in which no less than 4 males took part, is the most extreme instance of such a fight directly 'for' a female. In some cases the male may be seen not to chase his rival, but to be angry with his own wife. I believe this happens when the rival on former occasions has already shown not to be willing to yield, so that the male's attempts to chase him must remain unsuccessful. A description of such a case it given under April, 5th, 1926, and here cited: A neighbouring male approaches female A rather closely and she sometimes seems to follow him. All at once her husband flies up to her and alights beside her, while she crouches down. He has the head high, the crest erected and looks quite angry.

Similar other observations seem to fail in my diary notes, but I did make them on several occasions and was more than once struck by the anger of the male with his wife in such cases. Huxley (1914, p 521), when describing flirtations in the great crested grebe, says that all the anger of jealousy of the rightful mate is directed against the usurper, not against the mate- which again is distinctly human. It follows from this that he has not seen cases in which the mate itself is chased, but this probably need not show that such cases would be altogether absent. It is of interest that the mate may be seen to chase his wife for flirtations notwithstanding the fact that a quarter of an hour before he was busily "nesting" to attract a new female himself. This behaviour is typically polygamous and holds in the same way for a monogamous species with polygamous inclinations as in our own case. It is dominance which governs the behaviour of the male.

Resuming the points of interest in the sexual behaviour of the male we find that he marries a second female in the presence of the first one, does not tolerate that the latter chases her rival, neither that the rival chases his first wife, and finally is a very true husband to both, who copulates now with the one, then, with the other, covers and defends both nests, etc. Though he himself flirts often enough he does not tolerate that his wife flirts and may be angry with her as well as with his rival.

We thus come to the behaviour of the females. 
Jealousy is the prime motive for all doings of the male's first wife, as soon as the male shows an interest in a second female. One has only to read the observations on female Y of April 3rd, 1927, to see how furiously she may behave, even from the very first beginning and during the male's presence. Nothing resembling submission to the male is to be found. Such a case is rare however. As a rule the male can "marry" (scrape with) a second female largely unhindered by his own wife and the instances mentioned above, where he has to chase her from the very first beginning, because she is so aggressive towards the new female, are more or less exceptions. We can certainly say that the female, expressed in human language, submits mostly to her husband. So dominance governs the behaviour of the male, submission that of the female.

I stated already that all anger of the male's wife is exclusively directed towards the new female, in no way towards the male. When the male flirts the female is angry with her rival only, not with her mate. When the female flirts, however, the male is angry with his rival as well as with his wife. This is certainly interesting for comparison with human behaviour.

Also the great difference in the behaviour of different females, as described above, is interesting. Huxley's remarks to the effect that in the great crested grebe all the anger of jealousy of the rightful mate is directed against the usurper, not against the mate, seem to hold for male as well as female. I do not think, however, that Huxley's observations were sufficiently conclusive in this respect.

The behaviour of the second female does not differ much from that of the first. It is only natural that in the beginning, being on "foreign ground", she does not start chasing the male's wife at once and is chased herself first. It is typical for her, however, that she sticks to the territory at once and after being chased returns. After some time, however, she feels at home and may start chasing the first female, just as she was chased herself in the beginning (see above). This shows that she feels just the same jealousy of the first female, as the latter feels of her.

As already stated above heavy fights may occur between both females, so that the male chases now the one, then the other. Very interesting observations concerning such a combat are described under April 3rd, 1927. Females Y and Z are wildly fighting, Y running in upon $\mathrm{Z}$ every time and not bothering about the male, whereas $\mathrm{Z}$ positively refuses to leave. Finally $\mathrm{Y}$ begins scraping. Every time she does so female $\mathrm{Z}$ becomes furious and tries to chase $\mathrm{Y}$ away, so that the combat is renewed again and again. Sometimes female $\mathrm{Z}$ is the aggressor, then female $Y$. The male seems desperate. He flies from the one to the other and back again, is angry with both, but the females scarcely mind him. When he chases Y she crouches down in a tuft of grass, each time the same, refusing to leave it, though he pecks her several times. As soon as he has left, she continues scraping. This scraping of the female on April 3rd looked to me more or less like a challenge towards the other one. On the other hand, it is also described in my diary notes for April 13th and 14th, 1926, and these latter observations seem to show that the scraping - just as it does in the male - first of all means attracting the opposite sex, i.e. the male.

I have several times asked my self what human behaviour would agree with the scraping described above. How do two female human beings behave when they try to win one and the same man? I believe, when they behave naturally they are quite excessive, showing 
themselves to the very best of their advantage. They unconsciously "demonstrate' to attract the man. I think the behaviour of these female lapwings can be compared with that.

N.B. For a strange kind of flying of female A, see under 11 May 1926, compare also p. 23 of this paper. We have not dealt with the behaviour of the female herself towards neighbouring males. Though a female, which has given herself to a certain male, in general attaches herself to him and does not surrender herself to another male, here too exceptions are the rule, especially when the female is much chased by the male after he has got a second or even a third wife. The first step of such behaviour is the interest shown by her towards the other male in question. Such a case is described for April 5th, 1926. The anger of the male makes the second step impossible here. Selous and Huxley described similar cases for Podiceps cristatus. The second step, scraping is described for the lapwing under April 30th, 1926. A new male though attacked a very long time by the male of our observations, does not yield and is after some time busily engaged with scraping, "so long and persistently as, I think, I never saw before". I do not understand why he is to assiduous until after some time I discover he has really succeeded in attracting a female, with whom he is busily scraping. As far as I can judge this female is female A, belonging to the male of our observations. This male does no longer try to chase away the other male now. - "If this long combat between the two males has really concerned female $\mathrm{A}$ it is interesting to note that the latter during and after the fighting of the two males constantly called kee-weet". The third step is that the female surrenders herself wholly to the new male. Female Y, after having been "married" with her male for two or three weeks, changes her mate for another, with whom she is twice seen to copulate on April 18th, twice on April 20th, 1927. When her former husband alights beside her, he is twice chased away by the new male. On May 8th, however, she is seen to copulate with her former husband again. Female $\mathrm{X}$ in the same way changes her mate for another after about two months (May 29th, 1927). We thus see that notwithstanding the attentiveness and anger of the male now and then females may flirt with and even marry neighbouring males, though this is perhaps mostly due to the fact that the male neglects or chases his wife after having attracted another female.

I should add the following remarks of Brock here. "In the absence of her mate, the female shows her dislike or distrust of the approach of a strange male by running from his unwelcome advances, even taking wing to avoid him. Such encroachment rarely occurs during the presence of the legitimate male. The bird in possession, in fact, enjoys a strong moral advantage, which is seldom overcome. I have noted no serious attempt by unpaired males to forcibly deprive a male of his mate'. - It follows from my description that such a state of affairs does not at all hold: though it is true that unpaired males make no attempts to forcibly deprive other males of their mate even paired males attempt again and again to deprive them unforcibly, viz. by scraping. But Brock did not know he gave an example of a bigamous male himself.

Before finishing these particulars I must not forget to mention the great interest taken (and expressed) by the female in all the doings of the male. I saw this on several occasions, but find it specially mentioned under April 3rd, 1927. "The male begins flying his love flight, while both females, a short distance apart, follow his movements with their eyes, turning and stretching their necks. Also when the male is fighting with a rival they follow him attentively". And again: "It is interesting to note that female X, in the tulips, was uttering her complaining "kee-weet" on several occasions: when the male was scraping, and female Y went up to him, every time when he was wildly fighting or when he was chasing other males, 
apparently every time when he came flying over her, and further, I believe, when the two females, Y and Z, fought so furiously, finally when female X flew away herself. Her excitedness made it possible to state very nicely what interested or even excited her and she showed quite plainly how especially all doings of the male interested her very much". Again on May 29th, 1927, I noted: "another quite interesting point was that the new female on her nest was continuously softly crying each time when the males were fighting, also when her own male was not among the fighters. Thus the heavy fights formed a strong emotion not only for me, but also for her".

It is worth while to summarize the behaviour of male and both females once more, but now in connection with each other. The description gives an idealised example. We are dealing with a married couple. A second female appears on the scene and the male walks in her direction and starts courtship flying in her neighbourhood, continued by "nesting" (skipping, scraping, throwing). After a long time of scraping the new female begins walking up to the male and finally joins his "play". The first female, the male's wife, may walk about some distance away and crane her neck to follow what is going on. She may also be brooding; I do not know how she reacts in that case. After some joint nesting the male starts courtship flying again and finishes his flight by copulating with the new female. He starts nesting again and tries to attract her, but when she does not come up to him he starts feeding and gradually walks to another part of the territory. In the meantime the first female, provided she is not brooding, walks in the direction of the second one and begins chasing her. As soon as the male sees this he comes flying up towards them and, quite angry, chases his own wife, the first female. She tries, while alighting, to chase the new one again, but has to stop this, because the male makes it impossible. All three go on feeding now, but the least inattentiveness of the male may cause a new chasing. After some time the new female too may take the initiative in chasing.

Finishing my conclusions I may repeat what I stated in the introduction: I think my observations distinctly show how large a part of our sexual behaviour rests on the same instinctive base as that of the lapwing; man and lapwing show the same instinctive jealousy of male and female when love is concerned; both may under certain conditions, when opportunity offers itself, become disloyal to their true husband; but the most striking point is that in lapwings - as in man - the female may subject itself to the disloyal males whereas he himself does not permit the female to behave in a like manner. Finally, I may add that the mere fact of the outspoken jealousy of the females in lapwing and man should be considered sufficient proof that the lapwing notwithstanding its polygamy should be called monogamous. Brunhilde Laven (p. 29) in this conclusion agrees with me and sums up her views in these words: "Doch kann man sich bei anhaltender Beobachtung solcher Vorgänge unmöglich des Eindrucks erwehren, dass der Vogel psychische Erregungen erlebt, die uns Menschen genau so eignen",35.

Finally I want to compare the polygamy of the two species studied by me: grey heron and lapwing, and briefly to see what can be said about polygamy in monogamous birds in general.

${ }^{35}$ Yet, during continual observation of such events, one cannot help getting the impression that the bird experiences psychic excitements which are exactly the same for us humans. 
In my paper on the grey heron I have described a number of brooding females being what I called assaulted by married males, which tried to copulate with them, but did not succeed through the female's opposition. On first becoming acquainted with the lapwing I supposed that such assaults would occur in this species just as in the heron, and my first observations, of May 1925, appeared to prove this to hold true. Later on, when I became better acquainted with the birds I did not see such assaults anymore, and I am now sure I actually never saw them, the former so called assaults in my mind being based on inexact observations. I mean to say that I never saw a male lapwing, who tried to forcibly copulate with a female, as my male herons did. The birds taught me that if a male becomes interested in a paired female he will try to allure her by scraping and when the female then returns his interest - either by scraping with him, or at least by walking up to him - copulations may follow. But never would the male persist in endeavours to copulate in case the female would not allow copulation.

I state this so emphatically, because Brunhilde Laven (p. 31) does describe for the lapwing what she calls assaults (Übergriffe). Her observations concern a male she calls "Haremsmann", which was mated with her female C. The latter had a full clutch since April 18th. If I understand Brunhilde Laven well Haremsmann was still seen to copulate with his mate on April 22nd. That same day he was also seen to copulate (once) with a neighbouring female called A, which according to Brunhilde Laven was mated, but had no nests and also (again once) with another female, B, which was also mated and had a nest with two eggs. The latter copulation took place in the presence of male B, who flew up to encounter Haremsmann before the latter copulated, but sat down again at once, so that Haremsmann was more or less allowed to copulate with B's wife. - Again on 23 and 24 April, Haremsmann was once seen to copulate with another female than his own wife.

This description contains two statements, which I think, may mislead the reader. First of all, the female lapwing would have copulated with Haremsmann, though she was in possession of a mate. This, therefore, would represent an instance of protrandry, a point to which I return below. Secondly, Brunhilde Laven calls these copulations assaults (Übergriffe), though she names them assaults towards males ("Übergriffe einzelner Männchen in die Rechte anderer" ${ }^{36}$ ). And because there is a great difference between the assault described by me for the grey heron and those described by her for the lapwing I should define my term assault somewhat more precisely. For the point is that such assaults as are not uncommon in the heron do not occur (or at any rate are very rare) in the lapwing.

In human life, when speaking about assaults, we are as a rule dealing with cases in which a wife surrenders herself to another man in the absence of her husband or in which the reverse takes place. We call this assault, though both the wife in question and her friend (or the man in question and his shefriend) love each other, at least for the time being. This apparently is, because our character and law teach us that it is not allowed to marry more than one person of the other sex at the same time. For where marriages between a male human being and more than one female are lawfully permitted we do no longer speak about assaults. There the word would probably be used only in cases in which one wife would show sexual relations with two males. Therefore, the human meaning of the word is clearly a by-product of our civilization ${ }^{1}$.

${ }^{36}$ Violation of individual males of the rights of others 
Man is essentially monogamous. This is of value for the welfare of the family. But nature has to protect propagation. From both contradictions the constant friction between the two instincts to behave monogamously, and to give way to sexual desire, results. Society rules partly protect the family by forbidding marriages of more than two people. The result is that either such marriages may be dissolved again, or that they are accompanied by unofficial secondary love relations in cases where sexual relations with a third individual develop. Society rules may also protect the family by permitting marriages between more than two persons, always of one male with more than one wife. I think protection of the family in one way is not a bit better than protection in the other, the method nature uses herself - instinctive jealousy, combined with intelligence - being more efficient speaking biologically.

Returning to the grey heron, where we find males trying to forcibly copulate with females opposing them, we are dealing with assaults which in human language are rare and far from normal. Returning to the lapwing we find the male in a number of cases to behave polygamously, just as the human male in so called polygamous races and part of the males in our own race. As will follow below it is in my mind uncertain that there are observations on the female lapwing behaving truly polygamously, that is to say, that they were ever seen to copulate with more than one male on the same day or within the same period of some few days. And I therefore should prefer not to use the word assault in the case of the lapwing either. It is therefore better provisionally not to use the word assault at all, but to state that in the grey heron forced copulations are not uncommon, whereas they are absent in the lapwing.

We may ask why this is so, why in the lapwing forced copulations, which are rather common in the grey heron, do not occur. And it lies at hand also to ask then why in the heron marriages of three, which are so common in the lapwings may be absent. For both facts may be expected to form two different aspects of one and the same subject.

I think marriages of three in the grey heron must be absent (or at least very rare), because the males territory consists of the immediate vicinity of the nest only. There is no place for two females which constantly fight. Furthermore, because the males thus get no chance to attract a second female to their territory - and it is in the territory, i.e. on the nest only, that the pairs are formed - their sexual needs, if not contended by their own wife, seek an outlet forcibly in the form of perversities towards neighbouring females. In the lapwing, however, such formations of couples of three are possible, notwithstanding the occasionally heavy fighting of the females, because the territory is so much greater. There is place for two fighting females. The male can therefore copulate at random so to speak and such perversities as are of rather common occurrence in the grey heron need not occur here. It is possible that as an exception they may occur in the lapwing too, viz, when the male does not succeed in alluring a female. We should keep in mind, however, that in the grey heron such perversities are more or less facilitated through the fact that the males may leave the colony for a long time in succession and fly far away, so that a neighbouring male can easily interfere, the more so because its distance to the neighbouring female is very small. The male lapwing, on the contrary, is nearly always present in his territory, so that neighbouring males cannot easily reach a mated wife. The distance to a neighbouring female is greater here, but this matters little, because the male copulates by alighting on the female.

So it would in the first place be the size of the territory combined with the fact that the territory in the lapwing also fulfils feeding conditions and in the grey heron does not, what would cause these striking differences in behaviour between two monogamous species with 
polygamous inclinations. This supposition is supported by observations of Welter (1935, see Kluyver et al., 1940 p. 30-33) on Telmatodytes palustris, an American wren, which is polygyn. The females mated with one male are intolerant towards each other. They build their nests within the limits of the same male territory, but as far from each other as possible so that their jealousy does not interfere too much. Kluyver et al. state that in the European wren, Troglodytes troglodytes, this building of nests at some distance from each other apparently does not occur, but they also state that they probably tolerate each other.

I conclude from all this that we cannot easily judge on the eventual difference between the grade of polygamy of grey heron and lapwing, as it is presented under two different aspects. I think, however, that there is very little difference between both in this respect. This conclusion should, of course, not be generalized for other monogamous species. One constantly wonders why nature has evolved so many differences in behaviour and certainly in sexual behaviour, in as many species, even if nearly related. As stated above I still want to see what is known about polygamy in other monogamous species of birds. We will at the same time have occasion to deal with the observations of Brunhilde Laven, according to which the females with which "Haremsmann" copulated were mated already. These females would therefore represent an instance of polyandric behaviour and it seems worth while to deal with this point in somewhat more detail.

\section{Information concerning bigamy in birds in the literature}

I stated already that I had hoped to be able to add to this paper a special chapter on polygamy in monogamous species of birds. I have to refrain from this, because a thorough search of the literature would take me too much time. Incomplete study of the literature however, brought forth a number of facts, and these are here summarized. Of course, those instances in which the birds of a pair change mates between two successive broods, find no mention here.

Bigamy, then, as an exception, has at least been found to occur in the otherwise monogamous species listed in Appendix 1. In this list, a small number of cases occur in which the size of the clutch and the type of the eggs make it probable that two females laid in the same nest. It should be remarked, however, that the size of the clutch give certainty that two females were involved, but never that these were mated with one and the same male. This is well shown by those rare instances, in which birds of two different species laid and were incubating their double clutch together; compare the instance of lapwing and reeve mentioned by A.A. van Pelt Lechner (Ardea vol. 14, p.56 1925).

Here it is impossible that the birds were mated with one male, and the same uncertainty must therefore hold in other cases where the two females involved were of the same species and direct observations on the birds themselves were missing.

Numerous instances are to be found in literature of a clutch greater than normal, without the eggs being incontestably of two different types. In these cases it must remain uncertain whether the eggs were laid by one or two females. There is no doubt, however, that many of these cases are relating to one female laying a greater clutch than is normal for the species. Jourdain (1935) has summed up all he knew about the occurrence of a clutch of 5 instead of 4 in the waders, and his list is a long one. "The most familiar instance in which the five set occurs, to European naturalists at any rate, is the lapwing, Vanellus vanellus. and cases are a too numerous to specify in detail". There are indications that certain females regularly lay 5 
instead of 4 eggs, compare the instance of Limosa limosa (5 eggs on 15 May 1921 and 5 May 1922 on a same islet) and that of Vanellus clutches of 5 for 4 years in succession cited by Rinkel (1940, p. 76) and these make it possible that cases of clutches of 6 and even more when found in the waders, cannot be cited as certain instances of two birds laying together either. As to the lapwing, several cases of 6 have been described and de Vries draws attention to a case, in which the territorium in question was inhabited by one pair only and in which all the eggs were of the same type (C.N.V. VI, p. 22, see also C.N.V. 16, p. 125). It is possible, however, that such eggs belonged to two succeeding broods, compare Rinkel's experiments on the results of egg removal.

When, now, we try to make out what general conclusions can be drawn from the above list of data we find, first of all, that by far the majority of these cases of bigamy represent instances of true polygyny of a male mated with more than one female, whereas the reverse is very rare. In some few cases (Podiceps cristatus, Larus argentatus) the female, though mated, may "flirt", but cases of ttue polyandry in monogamous species are apparently hardly known. The list contains the case of two male kestrels copulating with one female. The cases of what seems polyandry in the starling may be concerned with one pair and an unmated male. Kluyver (1933, p. 34) remarks that such unmated males in this species are not rare and he gives evidence (1938, p.97) that cases of numbers of three are mostly due to the joining of these males in the work of cherishing or feeding the young of a neighbouring pair. Biologically speaking, the rare occuffence of polyandry is of advantage to the species as the young will have a greater chance to survive when the mother can give them all her time. The way in which this aim is reached is not quite clear to me, however. Probably the female physiologically, has little need for a second mate, because she is much absorbed in caring for her progeny (offspring) and, in case she enters a new cycle, always finds the male sexually ready. This is well shown by such cases where the sexes (also the female) change mates between two succeeding broods in case the first mate does not respond to the sexual desire of the other. It should be added that something like this plays also a part in some species in which such polygamy is the rule, e.g. the European wren see Kluyver et al., 1940 p. 45) and a bishopbird Euplectes hordacea (Lack 1935). In the wren the male may try to win a second female even from the moment the former has begun laying, though later, when the young are fledged, he participates in their care. Secondly, however, the dominance of the male may have something to do with the matter, as it must be a more or less efficient means to keep other males away from the female. Both facts may play a part in the sexual life of man too, but I do not know what literature exists in this direction.

The third conclusion which may be drawn from the list is that in some species the two females involved lay their eggs in one and the same nest, whereas in others they apparently never do so. The sparrowhawk is a fine instance of the first group, the lapwing of the second. In connection with this fact the question arises whether in the two females of these species, which lay their eggs in the same nest, jealousy, is wanting and, if so, why this is the case. I think it would be impossible far two lapwing females to brood a double clutch together, sitting side by side, as their jealousy would probably prevent them from approaching each other so closely. But if in the female spaffowhawk jealousy would not occur this species would be truly polygyn, as it is just the absence of jealousy which makes polygyny possible in truly polygynous species. Another possibility would be that the birds lay together, because the male does not assist in the building of a second nest, but I hardly think this can be the cause, and the question of jealousy would remain all the same. 
A further point of interest concerns the following question. Tinbergen (1939) has put together a number of cases of bigamy and drawn attention to the fact that in several of them "bigamy is favoured by the circumstance that the male remains sexually potent during a longer period than his mate, and a new mate is taken only when the original sex partner ceases to respond sexually; compare especially Tinbergen (1939, p. 44-46). In other cases bigamy may arise as a result of the death of the male bird of a pair, where upon the other unites with the neighbouring male. Besides, Tinbergen cites from literature three instances of birds in which the male mates with more than one female at about the same time, one of which is represented by my own observations on the lapwing. This gives the impression that cases in which a male is mated with two oestrous females at the same time are much rarer than those in which the second female is only taken after the first one has entered the non-copulatory stage. The above list shows that this is far from true. There are many cases of polygamy in monogamous birds, in which the male lives with two females from the time onward his first female is still oestrous.

Tinbergen is probably right in stating that bigamy is favoured by the passing of the first female into the non-copulatory stage, but arises without this favour in many cases. Here, again, we come to the conclusion that the want for a second mate lies, first of all, in the polygamous inclinations of some species.

The second noteworthy fact is that in some species polygamy occurs rather often, whereas in other species it is apparently quite rare. It attracts attention that I found no instance of bigamy in such a common species as the blackbird, whereas several cases are on record for the warblers. I lay stress on the warblers, because in them bigamy would be much more easily overlooked than in the blackbird. There is only one instance of bigamy in the kestrel over against several instances in the harriers, though the latter are much rarer. There are several cases of bigamy in the waders, but it is probable that the lapwing is an extreme instance even in this group. Now, we saw that the reason why bigamy appears to be much more common in the lapwing than in the grey heron may lie in the size of the territory and in the fact that the territory in the lapwing also fulfills feeding conditions and in the grey heron does not. This conclusion should not be generalized for other species.

A striking point in connection with the song flight op the lapwing and that of several other waders is that the flight is no less elaborate a performance than the song. If it has no other function than to make the bird conspicuous this is very strange. For most species of birds it is already sufficient, when advertizing themselves, that they sit high. This holds for many warblers, finches, thrushes, the great spotted woodpecker, the grey heron, cormorant, etc. A number of others make leaps or short excursions into the air, as we find in several gallinaceous birds, a number of warblers, pipits, larks, and the like. In all these species the flight itself is simple, though in the pipits the descending takes place with outspread wings and is more or less a performance, in the greenfinch we have an entity of song and flight resembling somewhat that of the waders (but I am not sure this is not a form of display in stead of song) and similar cases may occur here and there. But in the waders the flight has evolved to such an elaborate activity that one may ask whether making conspicuous really represents its only function. For though I do not deny that the lapwing is made still more conspicuous by zigzagging, rising to a greater height and tumbling, the whole performance looks much like an actual display i.e. like movements performed to stress the importance of special structures or colours. It should be remarked, by the way, that the function of the song is no more than to bring the sexes to one another, or, as Tinbergen, $(1939$, p. 79$)$ still better 
puts it, to attract a male from afar. To come to pair formation, however and, especially to reach the stage of copulation, one or the other form of stimulation by display is necessary, what has led to the development of in numerable and most divergent instances, defying any trial to classify them.

What, now, I mean to say is that the song flight of the lapwing takes so much the form of a display, of courtship, that one wonders whether not some display function may be contained in it, besides its song function. The same holds for the song flights of other waders: the godwit, redshank, plovers, etc.

Now, there is one fact, which in my eyes leaves no doubt that the song flight of the lapwing is used for display. In fact, I knew it was used as such long before I realized how strange this was in view of the fact that it also represents the song. On some occasions the male lapwing may perform his zigzag woo-flying in wider or narrower circles around a courted female for many seconds at a time. Observations on such behaviour are given in my diary notes for 13 and 16 May, 1926 and 29 May, 1927, contained in the second half of this paper. In these cases of bigamy are known for them, in reality how the same polygamous inclinations as e.g. the grey heron, in which species, too, true bigamy will probably never be found. The other alternative is that there is much difference in the grade of polygamy in different monogamous species. Possibly also both causes play a part.

Returning to the case of apparent polyandric behaviour described by Brunhilde Laven for the lapwing we have found that polyandry in monogamous birds is quite rare. We have probably found only one instance of it: the kestrel. Further, judging from my own experience on polygamously behaving lapwings I think the females described by Brunhilde Laven were not mated with another male the day they copulated with Haremsmann. I myself never saw, during all my observations on polygamous birds, a female copulating with two different males on one single day.

This in itself is no evidence, of course, why another should not make such observations, but Brunhilde Laven has not seen this either, though it would have been easy for her to observe such double copulations in the two females in question if they really had two mates those days. The behaviour of her male B, moreover, appears to me to show that this male was not truly mated with female B on April 22nd; otherwise, he would never have allowed Haremsmann to copulate with his wife. I suppose that Haremsmann had shown dominance over the other male on a former occasion, that the other felt himself only partially proprietor of the territory and the female in question, and that the female no longer adhered to him. Brunhile Laven states that later, during brooding (incubation), both females had a mate, which certainly was the former, as it was not Haremsmann. It is not impossible, however, that the two females in question first had a certain male, lateron were attracted by the active Haremsmann and left their own male down, still later lost Haremsmann again to re-accept their former mate. My females X and Y of 1927 showed something the same. Brunhilde Laven's observations are probably too incomplete to give certainty on this point. Anyhow, they should not be cited as argument in favour of possibly polyandry as long as they are not supported by more observations. We may conclude from all this that there are hardly any well established cases of polyandry in monogamous species of birds, the kestrel being the only instance I found, but it is only stated that two males copulated immediately after each other with one and the same female and no further details are apparently known. 
Two points of more general interest in connection with these facts on polygamy should still find mention here. One concerns some particulars polygamous species have in common; the other concerns the dominance of the male. As to the particulars polygamous species have in common, there are remarks of interest by Lack and Kluyver.

Kluyver et al, (1940, p.44), referring to the observations of Ryves on the corn bunting, want to differentiate between instinctively polygamous and instinctively monogamous species. I rather should prefer to speak about species the physiopsychological organisation of which makes either polygamy or monogamy resp. more or less a necessity, but this does not alter the question. Kluyver's chief reason to differentiate between these two is, I believe, the grade of occurrence of polygamy in the species in question, and he also uses some criteria to fundate this differentiation. He believes the difference between them lies in the care the male bestowes on the raising of the offspring. According to him the male in monogamous species participates in brooding, guarding the nest, feeding the female and lateron rearing the young. Therefore, the courtship and song take an end as soon as the clutch is complete. Only in exceptional instances, under circumstances quite favourable to the development of polygamy, e.g. when there is an surplus of females, polygamy comes into being. 
This unfinished manuscript by Jan Verweij has been made available through Wader Study 124(1) at http://www.waderstudygroup.org/article/9294

\section{Literature}

Bahr, P.R. 1907. On the "Bleating" or "Drumming" of the snipe (Gallinago coelestis). Proc. Zool. Soc. Lond. 1907: 12-35.

Beusekom, G. van, F.P.J. Kooymans, M.G. Rutten \& N. Tinbergen. 1930. Het vogeleiland Schoonderbeek, Laren.

Brock, G.E. 1911. Lapwings (Vanellus vanellus) in the pairing season. Zoologist (Ser. 4)15: 296-304

Cinat-Thomson, H. 1926, Sexuelle Zuchtwahl beim Wellensittich (Melopsittacus undulates Shaw) . Biol. Zentralbl. 46: 543-552.

Cunningham, J.T. 1928. Modern Biology. Kegan Paul, Trench, Trubner, London.

Dewar, J.M. 1920. The law of territory. Brit. Birds 14: 89-90.

Geiser, S.W. 1924. The differential death-rate of the sexes among animals, with a suggested explanation. Washington Univ. Stud. 12: 73-96.

Gleg, D. 1925. On the nesting of the avocet in the Camargue. British Birds 19: 82-87.

Haviland, M.S. 1915. Notes on the courtship of the Lapwing. Zoologist (Ser. 4) 19: 217-225.

Holloway, R. 1915. Dog separating combatants. Zoologist (Ser. 4)19:316.

Holstein, V. 1927. Fiskehejren. Gads Forlag, Kopenhagen.

Howard, H.E. 1920. Territory in Bird Life. J. Murray, London

Huxley, J.S. 1912. A first account of the courtship of the Redshank (Totanus calidris L.).

Proc. Zool. Soc. Lond. 1912(2): 647-655.

Huxley, J.S. 1914. The courtship habits of the Great Crested Grebe (Podiceps cristatus); with addition to the theory of sexual selection. Proc. Zool. Soc. London 1914(2): 491-562.

Huxley, J.S. 1934. A natural experiment on the territorial instinct. British Birds 27: 270-277.

Jorritsma, K. 1931. "Polygamie" van een kievit? De Wandelaar 3 (April 1931)

Jourdain, F. 1935 Phalaropus inconstancy breeding

Kluyver, H.N. 1933. Bijdrage tot de biologie en de ecologic van den Spreeuw (Sturnus vulgaris L.) gedurende zijn voortplantingstijd. Thesis, Veenman, Wageningen and Versl. Meded. Planteziektekund. Dienst Wageningen 69: 133-166.

Kluyver, H.N., 1938. Over spreeuwen, Sturnus v. vulgaris L. in een dennen beplanting. Limosa 8: 8-15.

Kluyver, H.N., J. Ligtvoet, C. van den Ouwelant \& F. Zegwaard. 1940. Dc levenswijze van de Winterkoning. Limosa 13: 1-51.

Kortlandt, A. 1938. De uitdrukkingsbewegingen en -geluiden van Phalacrocorax carbo sinensis (Shaw \& Nodder). Ardea 27: 1-40.

Kortlandt, A. 1941. Met speurdersoogen in de Aalscholverskolonie. De Levende. Natuur 45: $72-76$.

Lorenz, K. 1935. Der Kumpan in der Umwelt des Vogels. Journ. f. Ornithol. 83: 137-213 and 289-413.

Lack, D. 1935. Territory and polygamy in a bishopbird, Euplectes hordeacea hordeacea (L.). The Ibis, Ser. 13, 5 p. 817-836

Lack, D. 1939. The display of the Blackcock. British Birds 32: 290-303.

Laven, H. 1940 Beiträge zur Brutbiologie des Sandregenpfeifers (Charadrius hiaticula L.). Journ. f. Ornith. 88: 183-287.

Laven, Brunhilde, 1941. Beobachtungen über Balz und Brut beim Kiebitz (Vanellus vanellus L.). Journ. f. Omithol. Ergänzungsband 3: 1 -M (Festschrift Heinroth).

Naumann, S.F. ( $2^{\mathrm{e}}$ Auflage 1905). Naturgeschichte der Vogel Mitteleuropas vol 8

Nice, M.M. 1936. The nest in the rose-hedge. Bird-Lore 38: 337-343. 
This unfinished manuscript by Jan Verweij has been made available through Wader Study 124(1) at http://www.waderstudygroup.org/article/9294

Nicholson, E.M. 1938- '39. Report on the Lapwing habitat enquiry 1937. British Birds 32: 170-191, 207-229, 255-259.

Paget-Tomlinson, 1939 (cited MS p 91 note on polygamy)

Portielje, A.F.J. 1928. Zur Ethologie bzw. Psychologie der Silbermöwe, Larus argentatus argentatus Pont. Ardea 17: 112-149.

Portielje, A.F.J. 1931. Versuch zu einer verhaltungspsychologischer Deutung des

Balzgebarens der Kampfsnepfe, Philomachus pugnax (L.). Proc. 8th Intern. Ornithol.

Congress Amsterdam: 156-172.

Raven, C.E. 1925. In praise of birds. Hopkinson, Reboussin R. 1911. Les colonies de Vanneaux huppes (Vanellus cristatus) dans les environs de Sargé. Rev. Franc. Ornithol. 2: 156-163.

Rinkel, G.L. 1940. Waarnemingen over het gedrag van de Kievit (Vanellus vanellus (L.) gedurende de broedtijd. Ardea 29: 108-147.

Ryves, Lt. Col. \& B.H. Ryves. 1934 The breeding habits of the Corn Bunting as observed in North Cornwall with special reference to its polygamous habit. British Birds 28: 2-26.

Selous, E. 1901 '02. An observational diary of the habits - mostly domestic - of the Great Crested Grebe (Podiceps cristatus) and the Peewit (Vanellus vanellus), with some general remarks. Zoologist (Ser. 4) 5: 339-350, 454-462; 6: 133-148.

Selous, E. 1905 diary notes

Selous, E. 1905. Bird Life Glimpses. ???Uitgever, London.

Selous, E. 1906/07. Observations tending to throw light on the question of sexual selection in birds, including a day-to-day diary on the breeding habits of the Ruff. Zoologist (Ser. 4)10: 201-219, 285-294, 419-428; 11: 60-65, 161-182, 367-381.

Selous, E. 1909/10. An observational diary on the nuptial habits of the Blackcock in Scandinavia and England. Zoologist (Ser. 4)13:401-413; 14: 23-29, 51-56, 176-182, 248-265. Selous, E. 1912. Origin of the social antics and courting of birds. Zoologist (Ser. 4) 16: 197199.

Selous, E. 1914. A diary of ornithological observations made in Iceland during June and July 1912. Zoologist (Ser. 4)18: 222-223.

Selous, E. 1916. On the sexual origin of the nidificatory, incubatory, and courting display instincts in birds: an answer to criticism. Zoologist (Ser. 4) 20: 411412.

Stubbs, F.J. 1912. Flight of the Common Snipe (Gallinago coelestis). Zoologist (Ser. 4) 16: 196-197.

Tinbergen, N. 1931. Zur Paarungsbiologie der Flussseeschwalbe (Sterna h. hirundo L..). Ardea 20: 1-18.

Tinbergen, N. 1938. Erganzende Beobachtungen uber die Paarbildung der Flussseeschwalbe. Ardea 27: 247-249.

Tinbergen, N. 1939. The behavior of the Snow Bunting in spring. Trans. Linn. Soc. New York. 5: 1-94.

Tolman, R. 1929. Charadrius dubius curonicus Gm., broedvogel van Soest. Ardea 18: 179180.

van Pelt Lechner, A.A. 1925 Legsel van Kievit (Vanellus vanellus (L.)) en Kemphen (Philomachus pugnax (L.)) in nest. Ardea 14: 56.

Verwey, J. 1927. Waarnemingen bij Noordwijk. De Levende. Natuur 32: 199-212, 236-242. Verwey, J. 1930. Die Paarungsbiologie des Fishreihers. Zool. Jahrb. Abt. AlIg. Zool. Phys. 48: $1-120$.

Welter, W.A. 1935. The natural historry of the longbilled marsh wren. Wilson Bulletin. 47: $1-34$. 
Appendix 1. Records of bigamy in otherwise monogamous birds from the literature.

\begin{tabular}{|c|c|c|}
\hline Passer domesticus & $\begin{array}{l}\text { male with } 2 \text { females. Both building nest. On April } 28 \text { th male is seen to copulate with } \\
\text { both, on May 10th there are } 8 \text { eggs, incubated by both females alternatively. Both } \\
\text { females fed and raised the young, but this often caused quarrels, though all the } \\
\text { previous time all had gone well. }\end{array}$ & $\begin{array}{l}\text { L.S. Kohler. Oologist. Aug. } 1930 . \\
\text { Beitrage, vol.6, p.211, } 1930\end{array}$ \\
\hline Fringilla coelebs & $\begin{array}{l}\text { One male copulating with } 2 \text { females, but it took no part in the care of the young of } \\
\text { one of them. }\end{array}$ & E. Knauer. Mitt. über die Vogelwelt, vol. 24, p. 138, 1925. \\
\hline Corvus frugilegus & $\begin{array}{l}\text { Male feeding } 2 \text { females on different nests; no other male fed them. Author does not } \\
\text { state why it was a male (probable because of the feeding). }\end{array}$ & $\begin{array}{l}\text { C.R. Grawen. Habits of Rooks. Zoologist, ser. 3, vol. 11, p. } \\
\text { 268-269, } 1887\end{array}$ \\
\hline Sturnus vulgaris & $\begin{array}{l}\text { Three starlings building in one hole and there the young ones grow up. Author } \\
\text { believes they are two males and one female, but this is uncertain. } \\
\text { Two males and one female together feeding one nest with young. } \\
\text { Two males without females cherish alternatively the young of a neighbouring pair. If } \\
\text { reaching the nest at the same time a quarrel ensued. Possibly they previously had also } \\
\text { helped to incubate the eggs; it is not known whether later they also fed the young. } \\
\text { Male mating with two females at the same time, first copulating with both of them, } \\
\text { later incubating both clutches at the same time. Females now and then show jealousy } \\
\text { It was observed several times that young was fed by three adults (p. 35), presumably } \\
\text { one pair and one male without female. }\end{array}$ & $\begin{array}{l}\text { O. Grabam. Polygamy in the starling. Zoologist, ser. 3, vol. 19, } \\
\text { p. } 307,1895 . \\
\text { Newstead. The food of some British Birds, Suppl. Nr 2, Journ. } \\
\text { Board of Agric. } 1908 \text {. } \\
\text { H.N. Kluyver. Over spreeuwen, Sturnus v. vulgaris. L., in een } \\
\text { dennen beplanting. Limosa., vol.8, p. 8-15, } 1938 \text { Unpaired } \\
\text { male starlings that do not get a female (Kluyver 1933, p 34). } \\
\text { F. Freitag. Aus dem Leben beringter Stare zur } \\
\text { Fortpflanzungszeit. Vogelring, vol. 8, p.8-IS, 1936. } \\
\text { Kluyver. Bijdrage tot de biologie en de ecologie van de } \\
\text { spreeuw gedurende zijn voortplantingstijd. Versl.en Meded. } \\
\text { Plantenziektenk. Dienst, nr 69. Wageningen 1933. }\end{array}$ \\
\hline
\end{tabular}




\begin{tabular}{|c|c|c|}
\hline $\begin{array}{l}\text { Troglodytes troglodytes } \\
\text { Troglodytes aedon } \\
\text { Telmatodytes palustris }\end{array}$ & $\begin{array}{l}\text { Different grades of polygamy. Polygamy is most developed in Telmatodytes } \\
\text { palustris, least in Tr. aedon }\end{array}$ & See Kluyver et al., 1940, p.34-37. \\
\hline Hirundo rustica & 3 birds feeding one brood. & F.C.R. Jourdain. Brit. Birds, Vol. 4, p.79, 1910. \\
\hline Muscicapa striata & Male with 2 female. Two separate nests quite closely together, hardly apart & $\begin{array}{l}\text { W. Sunkel. Doppelleben bei Singvögeln. Mitt. über } \\
\text { die Vogelwelt, vol. } 25, \text { p.45, } 1926\end{array}$ \\
\hline Lanius collurio & $\begin{array}{l}2 \text { females seen together on several occasions near a nest containing } 10 \text { eggs, clearly dividing themselves } \\
\text { into two lots of } 5 \text {. No male was ever seen. The eggs were ultimately removed.and proved to be infertile }\end{array}$ & A.L.W. Mayo. Brit. Birds, vol. 23, p. 128, 1929. \\
\hline Parus major & $\begin{array}{l}\text { Male with } 2 \text { females. Second female probably began laying when the first was } \\
\text { completing her clutch male apparently fed both hens. }\end{array}$ & $\begin{array}{l}\text { G.B. Gooch. A great tit triangle. Brit. Birds. vol. 29, } \\
\text { p.78-79, } 1935 \text {. }\end{array}$ \\
\hline Panurus biarmicus & $\begin{array}{l}\text { Apparently more than } 1 \text { female laying in one nest (p. 96-97) and proved infertile. } \\
\text { Thus there seems to be no doubt that it was a case of two females laying in one nest, without a single } \\
\text { male. (Example of homosexuality) }\end{array}$ & $\begin{array}{l}\text { O.G.B. ten Kate. Bijdrage tot de kennis van de } \\
\text { voortplantingsbiologie van Panurus biarmicus (L.). } \\
\text { Ardea, vol. } 17, \text { p. } 81-104,1928 .\end{array}$ \\
\hline Aegithalos caudatus & $\begin{array}{l}3-4 \text { birds in one nest } \\
4 \text { birds present in one nest with } 10 \text { eggs } \\
4 \text { birds feeding one brood. } \\
3 \text { birds feeding one brood } \\
3 \text { birds feeding one brood } \\
\text { Some cases of } 3-4\end{array}$ & $\begin{array}{l}\text { J.H. Bonhote, A.G.C. Tucker. Brit. Birds. Vol.4, p. } \\
\text { 209-210, 1910. C.N.V. 5, p. 21-25,...Brit. Birds, vol. } \\
\text { 1, p. 32, 1907. } \\
\text { Cerva vide Brit. Birds, vol. I, p. 62, } 1907 \\
\text { S. Whiting, Brit. Birds, vol.4, p. 78-79, } 1910 . \\
\text { John F. Wynne. Three long-tailed tits feeding. one } \\
\text { brood. Brit. Birds, vol. 22, p. } 38 \text {. } \\
\text { Paul Ruthke. Beitrage Fortpfl. biol. Vögel, vol.6, } \\
\text { p.212, 1930. }\end{array}$ \\
\hline Melospiza melodia & $\begin{array}{l}\text { Two cases of one male with } 2 \text { females. One of them developed when a female lost her male. A } \\
\text { neighbouring male then annexed her territory and mated with this second female. Male defended both } \\
\text { nests and fed the young of both. There were several unpaired males in the neighbourhood. }\end{array}$ & $\begin{array}{l}\text { M. Nice Relations between the sexes in song } \\
\text { sparrows. Wilson Bull., vol. } 45, \text { p.51-59, } 1933 .\end{array}$ \\
\hline Plectriphenax nivalis & $\begin{array}{l}\text { Male with 2nd female, after the first no longer allowed copulation, took a third mate after his } 2 \text { nd one } \\
\text { how passed into the non-copulatory stage. }\end{array}$ & $\begin{array}{l}\text { N. Tinbergen. The behaviour of the snow bunting in } \\
\text { spring. Transact. Linnaean Soc. New York, vol.5, p. } \\
42-43,1939 \text {. }\end{array}$ \\
\hline Emberiza calandra & $\begin{array}{l}24 \text { males owned } 45 \text { females, } 15 \text { of the males being plygamous; One male had } 4 \text { females, } 4-5 \text { males had } 3 \\
\text { females, } 9-10 \text { males had } 2 \text { females. The females may begin laying on about the same date or more often, } \\
\text { somewhat after each other. There are always different nests. No jealousy was shown by any female, the } \\
\text { relationship between the hens of one male being one of amity. Amorous molesting of females by } \\
\text { neighbouring male does not occur. }\end{array}$ & $\begin{array}{l}\text { Lt. Col. \& Mrs B.H. Ryves. The breeding habits of } \\
\text { the corn bunting as observed in North Cornwall with } \\
\text { special reference to its polygamous habit. Brit. Birds, } \\
\text { vol. 28, p. 2-26, 1934. } \\
\text { The same supplementary notes on the breeding habits } \\
\text { of the same corn bunting as observed in North } \\
\text { Cornwall in 1934. Brit. Birds, vol. 28, p.154-164, } \\
\text { 1934. }\end{array}$ \\
\hline
\end{tabular}




\begin{tabular}{|l|l|l|}
\hline Troglodytes aedon & $\begin{array}{l}10 \text { cases of polygamy on a total of 193 nests. The different females have different } \\
\text { nests. }\end{array}$ & $\begin{array}{l}\text { S.C. Kendeigh, 1937, Factors affecting yearly } \\
\text { abundance of passerine birds. Ecol. Monogr. 7, } \\
\text { p. 91-123. }\end{array}$ \\
\hline Troglodytes troglodytes & $\begin{array}{l}\text { 13 out of a total of 25 males studied were polygamous in the years 1937-1939. In some cases } \\
\text { males had 3 broods at the same time. As a rule the male took a later female after the former } \\
\text { had started brooding, but the females of two males were laying while the former mates of } \\
\text { these males were still laying and I male mated with 2 females at the same time. The different } \\
\text { females have always separate nests. }\end{array}$ & $\begin{array}{l}\text { H.N } \text { \& . Zegwaard. De Ievenswijze van den } \\
\text { winterkoning. Limosa. Vol. 13. p.1-51, 1940, } \\
\text { especially p.35-39. }\end{array}$ \\
\hline Telmatodytes palustris & Male is essentially polygamous. & $\begin{array}{l}\text { W.A. Welter. The natural history of the } \\
\text { longbilled marsh wren. Wilson Bulletin, Vol. } \\
\text { 47, p. 1-34, 1935. }\end{array}$ \\
\hline
\end{tabular}




\begin{tabular}{|l|l|l|}
\hline Limosa limosa & 2 very large nests with 7 eggs each, presumably built by birds of two pairs. & $\begin{array}{l}\text { F. Haverschmidt. Ardea, vol. 16, p. 45, 1927, } \\
\text { Beiträge Fortpfl. Biol. Vögel, vol., 4, p. 183- } \\
184,1928 .\end{array}$ \\
\hline Numenius arquata & Two cases of a clutch of 6, presumably the produce of 2 hens. & $\begin{array}{l}\text { C.B. Chambers. British Birds, vol. 17, p. 170, } \\
1923 . \text { W.J. Eggeling. British Birds, vol., 23, p. } \\
195,1930 .\end{array}$ \\
\hline Burhinus oedicnemus & Clutch of 4 & $\begin{array}{l}\text { A.G.J. Portielje. Zur Ethologie Psychologie der } \\
\text { Silbermöwe. Ardea vol., 17, p. 148 note I, 1928. }\end{array}$ \\
\hline Larus argentatus & Flirtations of mated male with unmated female & Beiträge vol 3., p.28, Aguila 1926, p.289. \\
\hline Phylloscopus trochilus & Male with two females & $\begin{array}{l}\text { H.E. Howard. The British Warblers. London. } \\
\text { Part 6, p. 18-22, 13 1911. } \\
\text { P.H. Trahair Hartley. British Birds, vol. 28, } \\
\text { p.78, 1934 }\end{array}$ \\
\hline Phoenicurus phoenicurus & $\begin{array}{l}\text { Male with 2 females, first female first egg about May 1st, second female about May 13the } \\
\text { Two nests 12 yards apart. One nest with well feathered young which flew on June } \\
\text { 18th or 19th. The second held young which were fledged on June 27th or the } \\
\text { morning of the 28th. Hens, when foraging for food, were on friendly terms, } \\
\text { continually passing alone to each other's nests without arousing resentment. }\end{array}$ & $\begin{array}{l}\text { H.G. Hurrell. A Chiffchaff Triangle British } \\
\text { Birds, vol. 28, p.142-144, 1934. }\end{array}$ \\
\hline Phylloscopus collybita & $\begin{array}{l}\text { Male with 2 females. One female laid her first egg on May 8th and completed her clutch } \\
\text { by May 12th, but she did not incubate. On June 2nd the same male, with one female, was } \\
\text { feeding young in a nest 180 yards from the first. The young left the nest on June 4th. } \\
\text { Calculating back this female must have begun laying a few days before the first female } \\
\text { began. The latter was building a second nest 30 yards from that of 2nd female on June 9th } \\
\text { and the first egg was laid on June 13th. On one occasion male was seen to chase first } \\
\text { female he was accompanied by 2nd one who her brood for this purpose; later on, on again, } \\
\text { one hen was pursuing the other. }\end{array}$ & \\
\hline
\end{tabular}




\begin{tabular}{|c|c|c|}
\hline $\begin{array}{l}\text { Emberiza calandra } \\
\text { (continued) }\end{array}$ & $\begin{array}{l}4 \text { males with } 2 \text { females each } \\
7 \text { males with } 3 \text { females each } \\
2 \text { males with } 4 \text { females each } \\
2 \text { males with } 7 \text { females each } \\
\text { Some may have had more, one male had } 2 \text { females, laying their first egg } \pm 24 \text { June and } 5 \\
\text { all nest building on } 14-16 \text { July, laying their first egg on } 15,15,17,18 \text { and } 19 \text { July } \\
\text { (juvenile ones seemed to feed the chicks). Never jealousy. }\end{array}$ & $\begin{array}{l}\text { Supplementary notes on the breeding habits of } \\
\text { the same corn bunting as observed in North } \\
\text { Cornwall in } 1934 . \\
\text { British Birds, vol. } 28, \text { p.154-164, } 1934 \text {. } \\
\text { C.G.B. ten Kate. Bijdrage tot de kennis van de } \\
\text { voortplantingsbiologie van Panurus b. } \\
\text { biarmicus. Ardea vol. 17, p. } 81104,1928 . \\
\text { C.B.G. ten Kate. Beträge Fortpflanz. Biol. } \\
\text { Vogel vol.7, p. 1-7, 44-47, 1931 }\end{array}$ \\
\hline Panurus biarmicus & $\begin{array}{l}\text { Some cases of laying of } 2 \text { females in one nest. Observations, whether polygamy } \\
\text { occurred, are wanting, but author assumed partial polygymy. }\end{array}$ & $\begin{array}{l}\text { C.G.B. ten Kate. Broedbiologische } \\
\text { waamemingen aan de baardmus Panurus b. } \\
\text { biarmicus (L.). Orgaan Club Ned. Vogelk., vol. } \\
\text { 5, p. 21-27, 1932. }\end{array}$ \\
\hline Cygnus olor & $\begin{array}{l}6 \text { cases bigamy described from literature and } 1 \text { from personal observation; all concern } 1 \\
\text { male with } 2 \text { females. In some instance the association lasted far more than one year. There } \\
\text { was rather much diversity in the role of the male: he might serve and guard the females, } \\
\text { but not incubate, or incubate one nest only, or, again, both. In one case the association } \\
\text { developed apparently as a result of the death of a male; in another case the male courted } \\
\text { and paired with a second female outside his territory, whereas inside the latter he attended } \\
\text { to the first female; in two cases the male only took the second female after the first had } \\
\text { started incubation, but this, of course, was not the case in the associations lasting far more } \\
\text { than one year. In all cases the nests were built at some distance apart. } \\
1 \text { male apparently mated with } 2 \text { females in } 1934 \text {. Cygnets hatched in both nests within a } \\
\text { day or two of each other. Possibly } 1 \text { male with } 2 \text { females in } 1935 \text {. }\end{array}$ & $\begin{array}{l}\text { J.M. Dewar. Ménage à Trois in the Mute Swan. } \\
\text { British Birds, vol. 30, p. 178-179, } 1936 \text {. }\end{array}$ \\
\hline
\end{tabular}




\begin{tabular}{|c|c|c|}
\hline Podiceps cristatus & Flirtations of male with neighbouring female, and the reverse. & $\begin{array}{l}\text { E. Selous. An observational diary of the habits - } \\
\text { mostly domestic - of the Great Crested Grebe } \\
\text { (Podiceps cristatus). Zoologist, 1901, p. 161-1 } \\
\text { 83. 229-350, 454-562; 1902. p. 133-144. } \\
\text { J.S. Huxley. The courtship habits of the Great } \\
\text { Crested Grebe (Podiceps cristatus); with an } \\
\text { addition to the theory of sexual selection. Proc. } \\
\text { Zool. Soc. London, 1914,11, p. 491-562. See } \\
\text { especially p. 521-522 and p. 538 543. }\end{array}$ \\
\hline $\begin{array}{l}\text { Phalacrocorax carbo } \\
\end{array}$ & $\begin{array}{l}\text { Male copulates with at least three females, attracts a number of others (p. 23). manuscript: } \\
\text { Man ziet schijnbaar onverschillig toe als zijn vrouwtje copuleert met een andere man. } \\
\text { Vrouwtje wordt wel jalours bij het zien van een copulatie. Trouw van vrouwtje aan haar } \\
\text { man zeer groot. Een vrouwtje zit van } 22 \text { april tot minstens } 9 \text { mei bij haar man, die met een } \\
\text { ander trouwde (toen tweede broedsel kwam. Copulaties met meer dan } 1 \text { vrouwtje vinden } \\
\text { plaats zolang er nog geen eieren zijn. Daarna streng monogaam. }{ }^{37}\end{array}$ & $\begin{array}{l}\text { A. Kortlandt. De uitdrukkingsbewegingen en } \\
\text { geluiden van Phalacrocorax carbo Sinensis } \\
\text { (Shaw \& Nodd.). Ardea vol. 27, p.1- 40, } 1938\end{array}$ \\
\hline Ciconia ciconia & Male with two females with separate nests (1924). & $\begin{array}{l}\text { M. ?. Schenk zu Schweinsberg. Beiträge Fortpfl. } \\
\text { Biol., vol.6, p. } 94-95,1930 \text {. }\end{array}$ \\
\hline Circus pygargus & $\begin{array}{l}\text { Male with two females with separate nests (1924) } \\
\text { Male with two females with separate nests in } 1924 \text { (same case as above), } 1925,1929 . \\
\text { Male with two females with separate nests. Male was seen with both females from the } \\
\text { beginning at first jealousy of females. On these occasions the cock drove one female back } \\
\text { to her nest, before feeding hen No I. Nests } 70 \text { yards apart. Both hens fed by the male. } \\
\text { Male with two females with separate nests. } \\
\text { Male with two females with separate nests, all eggs. }\end{array}$ & $\begin{array}{l}\text { Tj. De Vries. Ardea vol. 14, p. } 70,1925 \text {. } \\
\text { P. Heus. Avifauna Limburg 1926. Aanvullingen } \\
\text { len II idem 1932. } \\
\text { G. Jent A case of bigamy in montagus Harrier. } \\
\text { British Birds, vol. 33, p. SI-52, } 1939 \text {. } \\
\text { F.C.R. Jourdain. British Birds, vol. } 33 \text {, p. SI-52, } \\
\text { 1939. Possibly the same case as that described in } \\
\text { vol. 19. } \\
\text { F.C.R. Jourdain. British Birds, vol. 17, p. } 288- \\
\text { 289, 1924, vol. 19, p. } 180,1925 \text {. }\end{array}$ \\
\hline $\begin{array}{l}\text { Circus cyaneus } \\
\text { hudsonius }\end{array}$ & Male with two females with separate nests. & $\begin{array}{l}\text { F.C.R. Jourdain. British Birds, vol. 17, p.288- } \\
289,1924 \text {. Vol. 19, p. } 180,1925 .\end{array}$ \\
\hline Accipiter nisus & $\begin{array}{l}\text { Male with two females with separate nests with } 150 \text { yards apart } \\
\text { Male with two females with double clutch in one nest. Both females probably brooding at } \\
\text { the same time, all eggs slightly incubated. }\end{array}$ & $\begin{array}{l}\text { F.C.R. Jourdain. British Birds, vol. 19, p. } 314 \text {, } \\
1926 \\
\text { F.C.R. Jourdain. Bigamy in the sparrow hawk. }\end{array}$ \\
\hline
\end{tabular}

${ }^{37}$ Male looks seemingly indifferent as his female mates with another male. Female becomes jealous when she sees a copulation. Faithfulness of the female to her male is very large. A female is from April 22 until at least May 9 with her male, which became mated with another (when second brood had arrived). Copulations with more than one female take place as long as there are no eggs. Then strictly monogamous. 


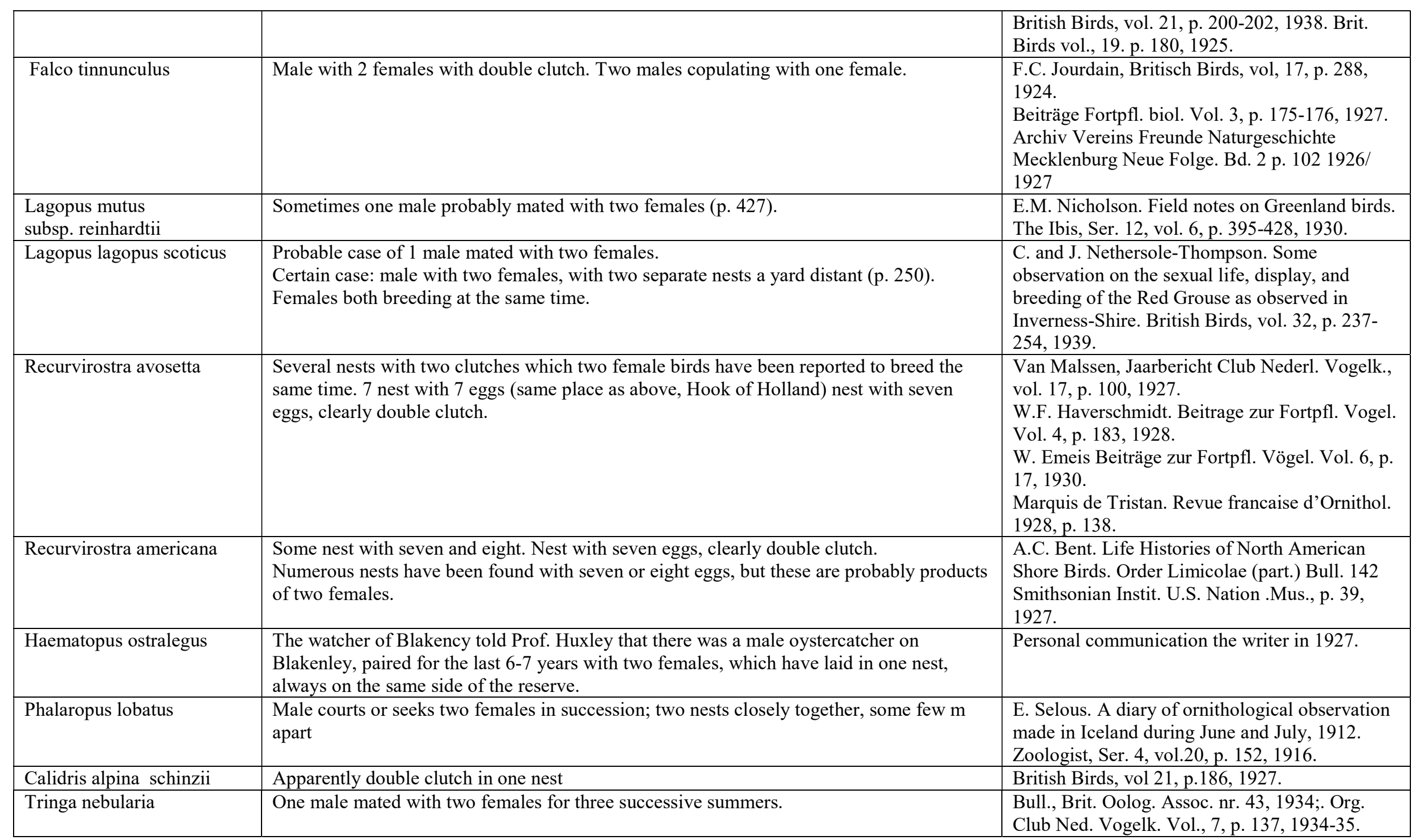

